\title{
MIDDLE PALAEOLITHIC
}

\section{IN NORTH-WEST EUROPE}

MULTIDISCIPLINARY APPROACHES

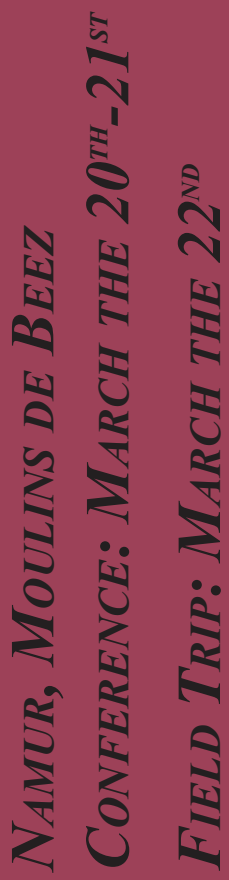

NAMUR 2014 N
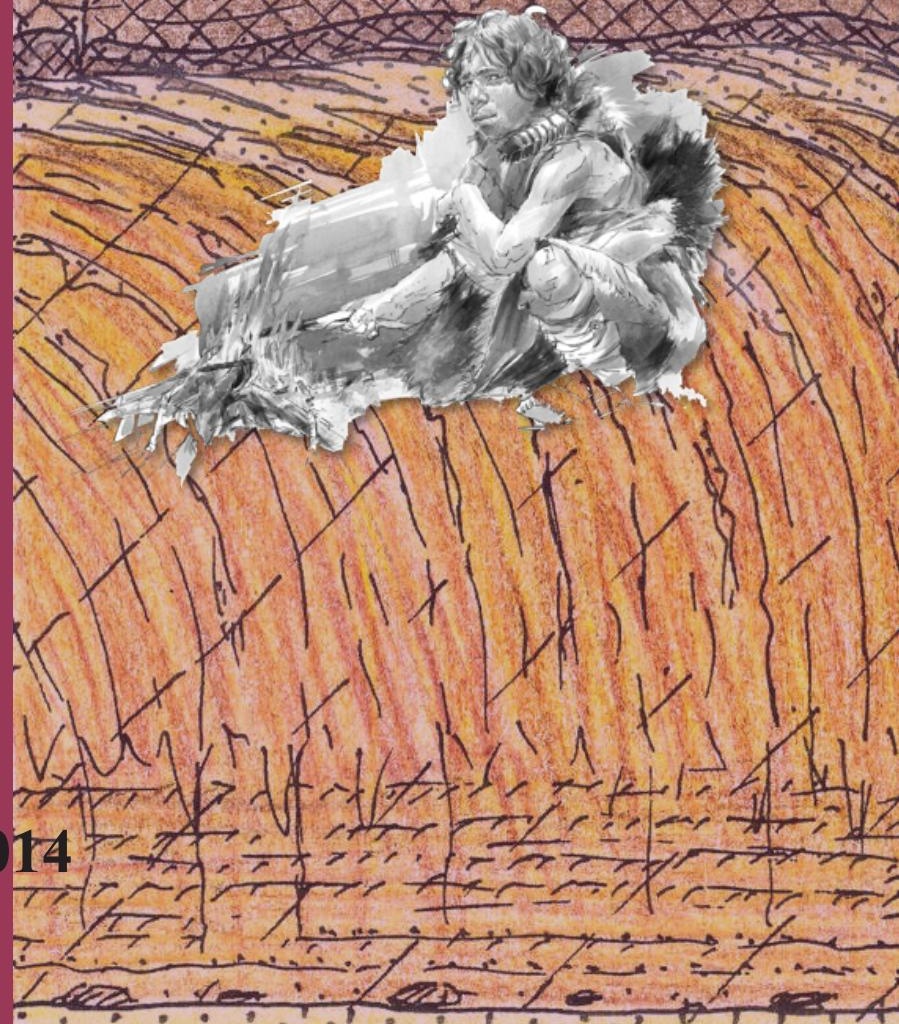



\section{Middle Palaeolithic in North-West Europe: MULTIDISCIPLINARY APPROACHES}

\section{BOOK OF ABSTRACTS}

\section{CONFERENCE ORGANIZED BY:}

KÉVIN Di MODICA

STÉPHANE PIRSON

MiCHEL TOUSSAINT

GRÉGORY ABRAMS

DOMINIQUE BONJEAN

With the logistic support of the "Cellule Events-DGO4" (SPW)

NAMUR, MOULINS DE BEEZ

CONFERENCE: MARCH THE $20^{\mathrm{TH}}-21^{\mathrm{ST}}$

FIELD TRIP: MARCH THE 22 $2^{\mathrm{ND}}$

$$
\text { - } 2014 \text { - }
$$


Cover illustration: detail of the stratigraphic $\log$ and refitting from Rocourt (after Haesaerts et al., 2011 in ERAUL 127); hare coxal bone bearing cut marks from Scladina Cave (after Bonjean et al., 2011 in Chronique de l'Archéologie wallonne 18); representation of the Child of Sclayn after B. Clarys 


\section{TABLE OF CONTENTS}

FOREWORD

Kévin Di Modica, Stéphane Pirson, Michel Toussaint, Grégory Abrams \& Dominique Bonjean

\section{PODIUM PRESENTATIONS}

THE EXPLOITATION OF FAUNAL RESOURCES IN NORTH-WEST EUROPE: UPDATED REVIEW OF THE MAIN SITES

Grégory Abrams, Patrick Auguste, Silvia M. Bello, Sabine Gaudzinski-Windheuser, Mietje Germonpré,

Lutz Kindler, Keiko Kitagawa, Petra Krönneck, Susanne Münzel, Simon Parfitt, Geoff M. Smith

\& Thijs van Kolfschoten

UPPER PLEISTOCENE LCESS-PALAEOSOLS RECORDS FROM NORTHERN FRANCE IN THE EUROPEAN CONTEXT: ENVIRONMENTAL BACKGROUND AND DATING OF THE MIDDLE PALAEOLITHIC

Pierre Antoine, Sylvie Coutard, Émilie Goval, David Hérisson, Jean-Luc Locht, Nick Debenham, Jean-Jacques Bahain \& Gilles Guérin

THE EARLY AND LATE MIDDLE PALAEOLITHIC OF BRITAIN COMPARED: DEVELOPMENTS IN TECHNOLOGY AND BEHAVIOUR

Nick Ashton, Simon Lewis \& Beccy Scott

EVOLUTIONS, BIOCHRONOLOGICAL AND PALAEOECOLOGICAL CONTRIBUTIONS OF MAMMAL ASSOCIATIONS IN NORTH-WEST EUROPE DURING THE MIDDLE PALAEOLITHIC

Patrick Auguste

NEANDERTALS OF THE CHANNEL RIVER VALLEY: NEW WORK AT LA COTTE DE ST. BRELADE

Martin Bates, Richard Bates, Ed Blinkhorn, Chantal Conneller, Clive Gamble, John McNabb, Marie-Anne Julien, Matt Pope, Beccy Scott \& Andy Shaw

FORMATION PROCESSES OF PALAEOLITHIC SITES: THE ROLE OF NATURAL FACTORS Pascal Bertran

LITHIC INDUSTRIES FROM THE BEGINNING OF THE WEICHSELIAN AT SAINT-ILLIERSLA-VILLE (YVELINES) AND THE QUESTION OF THE MICOQUIAN IN THE PARIS BASIN Frédéric Blaser \& Christine Chaussé

CARBON AND OXYGEN STABLE ISOTOPES $\left({ }^{13} \mathrm{C},{ }^{18} \mathrm{O}\right)$ IN TOOTH ENAMEL OF LATE PLEISTOCENE MAMMALS: TOOLS FOR RECONSTRUCTING PALAEOCLIMATE, PALAEOENVIRONMENTS AND PALAEODIETS DURING THE MIDDLE PALAEOLITHIC Hervé Bocherens, Grégory Abrams, Dominique Bonjean, Martin Cotte, Kévin Di Modica \& Christoph Wißing

THE RHEINDAHLIAN

Gerhard Bosinski

THE GREAT FOSSIL MINE OF THE SOUTHERN NORTH SEA: EXPLORING THE POTENTIAL OF SUBMERGED PALAEOLITHIC ARCHAEOLOGY

Rachel Bynoe, Justin Dix \& Fraser Sturt

CAVE PALYNOLOGY AS A TOOL FOR VEGETATION AND CLIMATE CHANGE RECONSTRUCTIONS DURING THE MIDDLE PALAEOLITHIC: MYTH OR REALITY?

$$
\text { Mona Court-Picon }
$$


NEANDERTAL OCCUPATIONS AND LAND USE IN KARSTIC ENVIRONMENTS FROM SOUTHERN BELGIUM AND SOUTH-EASTERN FRANCE DURING THE EARLY UPPER PLEISTOCENE: REGIONAL OR COMMON FEATURES?

Camille Daujeard, Grégory Abrams \& Mietje Germonpré

THE COLONISATION OF WESTERN EUROPE: COARSE AND FINE-GRAINED PERSPECTIVE Pascal Depaepe \& Wil Roebroeks

THE MIDDLE PALAEOLITHIC OF BELGIUM: CRITICAL REVIEW OF THE DATASET, GLOBAL OVERVIEW AND PROSPECTS Kévin Di Modica, Stéphane Pirson, Grégory Abrams \& Michel Toussaint

THE LAST NEANDERTALS IN NORTH-WEST EUROPE AND THE LINCOMBIAN-RANISIANJERZMANOWICIAN Damien Flas

PALAEOLITHIC LAND USE IN DUTCH AND BELGIAN LIMBURG, INTEGRATING ARTEFACT ASSEMBLAGE DATA FROM UPLAND OPEN AIR SITES Phil Glauberman

THE POINT DURING THE MIDDLE PALAEOLITHIC: REFLECTION OF A SPECIFIC STATUS IN NEANDERTAL HUNTING EQUIPMENT AND TOOLKITS Émilie Goval, David Hérisson, Jean-Luc Locht \& Aude Coudenneau

CHRONOSTRATIGRAPHIC CONTEXT OF MIDDLE PALAEOLITHIC IN THE LCES SEQUENCES FROM BELGIUM Paul Haesaerts

THE EMERGENCE OF MIDDLE PALAEOLITHIC IN WESTERN EUROPE David Hérisson, Nick Ashton, Laurence Bourguignon, Michel Brenet, Dominique Cliquet, Kévin Di Modica, Jean-Philippe Faivre, Jean-Luc Locht, Marie-Hélène Moncel, Matt Pope, Wil Roebroeks, Beccy Scott, Alain Turq, Ann Van Baelen \& Philip Van Peer

PLEISTOCENE RHINE-THAMES LANDSCAPES: GEOLOGICAL BACKGROUND FOR HOMININ OCCUPATION OF THE SOUTHERN NORTH SEA REGION Marc Hijma, Kim Cohen, Wil Roebroeks, Wim Westerhoff \& Freek Busschers

HOW MUCH NEANDERTAL IS IN US? Jean-Jacques Hublin

THE MIDDLE PALAEOLITHIC OF THE MIDDLE MOSELLE BASIN: AVAILABLE INFORMATION FROM LUXEMBOURG AND SURROUNDING AREAS Foni Le Brun-Ricalens

THE DISCOID TECHNO-COMPLEX (MIS 3) AT ORMESSON AND ACROSS THE PARIS SEDIMENTARY BASIN: CONSISTENCY AND FLEXIBILITY OF A SINGULAR TECHNICAL CHOICE WITH RELATION TO THE LITHOLOGICAL CONTEXT

Mathieu Leroyer, Pierre Bodu, Hélène Salomon \& Vincent Lhomme

NEANDERTAL OCCUPATION DURING MIS 5E AT CAOURS (NORTHERN FRANCE): A MULTIDISCIPLINARY STUDY Nicole Limondin-Lozouet, Jean-Luc Locht, Pierre Antoine, Patrick Auguste, Julie Dabkowski \& Bassam Ghaleb

THE MIDDLE PALAEOLITHIC OF NORTHERN FRANCE Jean-Luc Locht, Émilie Goval, David Hérisson, Pierre Antoine \& Sylvie Coutard

CONNECTING MIDDLE PALAEOLITHIC KARSTIC AND LESSIC SITES: WHERE DO WE STAND? 
THROUGH A NEANDERTAL'S EYE: WHAT DOES THE MIDDLE PALAEOLITHIC MEAN? THE STATE OF RESEARCH IN GERMANY

Jürgen Richter

EVALUATING FUNCTIONAL DATA ON TOOL USE, HAFTING AND SITE FUNCTION IN THE EUROPEAN MIDDLE PALAEOLITHIC Veerle Rots

NEW FOSSILS AT THE "TROISIÈME CAVERNE" OF GOYET (BELGIUM) AND THE MORTUARY PRACTICES OF LATE NEANDERTALS

Hélène Rougier, Isabelle Crevecoeur, Cédric Beauval, Damien Flas, Hervé Bocherens, Christoph Wißing, Mietje Germonpré, Patrick Semal \& Johannes van der Plicht

REGIONAL BEHAVIOUR AMONG LATE NEANDERTAL GROUPS IN WESTERN EUROPE: A COMPARATIVE ASSESSMENT OF LATE MIDDLE PALAEOLITHIC BIFACIAL TOOL VARIABILITY

Karen Ruebens

LCESS OF THE LOWER RHINELAND Wolfgang Schirmer

THE MOURNING DAWN: NEANDERTAL FUNERARY PRACTICES AND COMPLEX RESPONSES TO DEATH Sarah Schwarz

THE ADULT NEANDERTALS FROM SPY AND THE VARIABILITY OF LATE NEANDERTALS Patrick Semal, Isabelle Crevecoeur \& Hélène Rougier

THE LAST 500,000 YEARS OF HUMAN EVOLUTION IN EURASIA: FOSSIL AND GENETIC PERSPECTIVES Chris Stringer

EARLY PREHISTORY UNDER THE SEA: INVESTIGATING MIDDLE PALAEOLITHIC ARCHAEOLOGY AND SUBMERGED LANDSCAPES IN THE SOUTHERN NORTH SEA Louise Tizzard, Andrew R. Bicket, Jonathan Benjamin \& Dimitri De Loecker

NEANDERTAL MOBILITY PATTERNS IN THE MEUSE VALLEY: INSIGHTS AND PERSPECTIVES THROUGH STRONTIUM ISOTOPE ANALYSIS ON DENTAL ENAMEL Christine Verna, Michel Toussaint, Jean-Jacques Hublin \& Michael P. Richards

THE MIDDLE PALAEOLITHIC OF THE NETHERLANDS: CONTEXTS AND PROSPECTS Alexander Verpoorte, Marcel J.L.Th. Niekus, Dimitri De Loecker \& Eelco Rensink

INSIGHT INTO THE ECOLOGY OF NEANDERTALS IN NORTH-WEST EUROPE: STABLE ISOTOPES AND THEIR PALAEOBIOLOGICAL IMPLICATIONS

Christoph Wißing, Hervé Bocherens, Isabelle Crevecoeur, Cédric Beauval, Damien Flas, Mietje Germonpré, Patrick Semal, Johannes van der Plicht \& Hélène Rougier

\section{POSTERS}

WHEN NEANDERTALS FROM SCLADINA USED CAVE BEAR BONES AS RETOUCHERS

Grégory Abrams, Silvia M. Bello, Kévin Di Modica, Stéphane Pirson \& Dominique Bonjean

NEW CONTRIBUTION TO THE STUDY OF THE SMALL-VERTEBRATE ASSEMBLAGES OF SCLADINA CAVE (LATE PLEISTOCENE, PROVINCE OF NAMUR, BELGIUM) Hugues-Alexandre Blain, Juan Manuel López-García, Jean-Marie Cordy, Stéphane Pirson, Grégory Abrams, Kévin Di Modica \& Dominique Bonjean

SIMPLE PREPARED CORES AND THE ORIGINS OF LEVALLOIS 
THE MIDDLE PALAEOLITHIC SITE OF REMICOURT "EN BIA FLO” I (LIĖGE PROVINCE, BELGIUM)

Dominique Bosquet, Paul Haesaerts, Freddy Damblon, Paula Jardón Giner \& Caroline Ryssaert

IN THE FOOTSTEPS OF THE NEANDERTALS AT ROZEL (MANCHE), ABOUT 110,000 YEARS AGO

Dominique Cliquet, Philippe Alix, Patrick Auguste, Jean-Pierre Coutard, Émeline Deneuve,

Agnès Gautier, Norbert Mercier, Nancy Marcoux, Olivier Moine, Hugues Plisson, Philippe Ponel,

Emmanuelle Stoetzel, Élisabeth Tribouillard \& Brigitte Van-Vliet Lanö̈

LITHIC TECHNOLOGIES AMONG THE LATE NEANDERTAL POPULATIONS OF THE MEUSE

BASIN: SCLADINA CAVE MIS 3 ARCHAEOLOGICAL COMPLEX AS A CASE STUDY.

Justin Coppe, Dominique Bonjean \& Kévin Di Modica

MULTIPROXY RECORD OF ENVIRONMENTAL AND CLIMATIC VARIATIONS DURING THE MIS 5E MIDDLE PALAEOLITHIC OCCUPATION AT CAOURS (NORTHERN FRANCE):

COMBINING PETROGRAPHY, MALACOLOGY AND TUFA GEOCHEMISTRY

Julie Dabkowski, Nicole Limondin-Lozouet, Pierre Antoine, Jean-Luc Locht, Julian Andrews, Christine

Chaussé, Pierre Carbonel \& Alina Marca-Bell

CT SCANNING: IS IT TRULY NON-DESTRUCTIVE?

Isabelle De Groote, Chris Stringer, Cia Anderung, Tom Higham, Rob Kruszynski \& Rhiannon Stevens

WALOU CAVE (TROOZ): AN EXCEPTIONAL SEQUENCE FROM THE BELGIAN

PALAEOLITHIC

Christelle Draily, Stéphane Pirson, Mona Court-Picon, Wim Van Neer, Wim Wouters, Bjorn De Wilde,

Nick Debenham, Freddy Damblon \& Michel Toussaint

CONTEXTUALISING VOLUMETRIC LAMINAR STRATEGIES IN NORTH-WEST EUROPE

BEFORE C. 120,000 B.P.: AN INTER-REGIONAL STUDY

Christian S. Hoggard

RAW MATERIAL PROCUREMENT STRATEGIES AMONG THE BELGIAN LATE NEANDERTALS: THE CASE OF SCLADINA CAVE'S MIS 3 ARCHAEOLOGICAL DEPOSITS

Michael Horevoets, Kévin Di Modica, Stéphane Pirson \& Étienne Juvigné

THE MIDDLE PALAEOLITHIC IN EASTERN FRANCE: CHARACTERISTICS AND

COMPARISONS WITH NEIGHBOURING COUNTRIES

Agnès Lamotte

NEWS FROM THE NORTH. A MIDDLE PALAEOLITHIC SITE RICH IN HANDAXES ON THE DRENTHE PLATEAU, THE NORTHERN NETHERLANDS: FIRST RESULTS OF A TRIAL EXCAVATION

Marcel J.L.Th. Niekus \& Dirk Stapert

LA COTTE DE ST. BRELADE (JERSEY): RE-EVALUATING NEANDERTAL SUBSISTENCE BEHAVIOUR AND LANDSCAPE USE Geoff M. Smith

NO SMOKE WITHOUT FIRE (MAKERS?): THE SEARCH FOR FIRE PRODUCTION TECHNOLOGY IN MIDDLE PALAEOLITHIC EUROPE Andrew C. Sorensen

THE GREEN AMPHIBOLE ABUNDANCE AS A CHRONOSTRATIGRAPHIC TOOL IN MIDDLE PALAEOLITHIC SITES FROM BELGIUM Paul Spagna, Paul Haesaerts, Eric Meijs \& Stéphane Pirson

MOUSTERIAN TERRITORIAL ORGANISATION: THE EXAMPLE OF THE NORTHEAST AQUITAINE BASIN DURING MIS 3 AND 4 Alain Turq \& Jean-Philippe Faivre

TRACES OF OCCUPATION DURING THE MIDDLE PALAEOLITHIC IN LESS CONTEXT: SITES OF THE MONT SAINT-MARTIN IN THE HEART OF THE CITY OF LIĖGE (BELGIUM) Pierre van der Sloot, Stéphane Pirson, Paul Haesaerts \& Paul Spagna 
SPY CAVE (BELGIUM)

Kévin Di Modica, Stéphane Pirson \& Michel Toussaint

GOYET CAVES (BELGIUM)

Michel Toussaint, Stéphane Pirson \& Kévin Di Modica

THE SEDIMENTARY CONTEXT, ARCHAEOLOGY, AND ANTHROPOLOGY OF SCLADINA

CAVE (BELGIUM)

Dominique Bonjean, Grégory Abrams, Kévin Di Modica, Marcel Otte, Stéphane Pirson \& Michel Toussaint

\section{ALPHABETICAL INDEX OF AUTHORS}





\title{
FOREWORD
}

\section{Kévin Di Modica ${ }^{1}$, Stéphane Pirson ${ }^{2}$, Michel Toussaint ${ }^{2}$, Grégory Abrams ${ }^{1,3}$ \& Dominique Bonjean ${ }^{1,3}$}

\author{
${ }^{1}$ Scladina Cave Archaeological Centre, Andenne (Belgium); kevin dimodica@yahoo.fr \\ ${ }^{2}$ Direction of Archaeology, Public Service of Wallonia (SPW), Namur (Belgium) \\ ${ }^{3}$ Department of Prehistory, University of Liège, Liège (Belgium)
}

Over the past 25 years, our knowledge of the Middle Palaeolithic has considerably increased. Significant developments have been made in the different disciplines forming the basis of Palaeolithic research on chronology, chronostratigraphy, palaeoenvironment, human behaviour, physical anthropology, genetics...

These advances closely rely on data both from recent archaeological excavations and reexamination of old collections. The major development of preventive archaeology has provided significantly larger amount of field data. This dataset complements the data obtained from programmed archaeology and reappraisal of old collection.

The last major international conference focusing on the Middle Palaeolithic in North-West Europe took place in Amiens (France) in 2008. Six years later, the aim of the present conference is to provide a new international multidisciplinary synthesis on a broad territorial scale. Many researchers have been invited to present the key aspects of current research on Middle Palaeolithic in North-West Europe. They were strongly encouraged to integrate their data in an interdisciplinary approach.

The scope of this transversal approach is to decompartmentalize the different disciplines so that the contribution of each field of research can be appreciated within the larger field of archaeological issues, including cultural expression, territorial management and population dynamics, in both diachronic and transregional perspectives.

This conference also aims to provide an up-to-date overview of the available documentation on the Middle Palaeolithic of North-West Europe and to discuss the current research issues and debates on Neandertal behaviour in a multidisciplinary perspective.
Chronologically, the entire Middle Palaeolithic is discussed from its earliest manifestations and roots in the Lower Palaeolithic to the disappearance of Neandertals and the transition to the Upper Palaeolithic.

\section{Why North-West Europe?}

North-West Europe is a key area to decipher Neandertal societies in connection with their natural landscapes. The region contains varied contexts where lœssic, karstic, fluvial, lacustrine and coastal environments coexist. This area was also affected by significant climatic changes, with environmental conditions fluctuating from interglacial forest to polar desert. Moreover, the diversity of the geological substratum informs on the availability of various natural resources.

The geographic area considered is delimited on the south by the Loire Valley, the Massif Central and the Alpine arc, and on the east by the Bohemian Massif and the Oder Valley. This broad geographic region includes Middle Palaeolithic sites from various contexts in the discussion and will particularly encourage a dialogue based on data from open-air and cave sites.

\section{Why in Belgium?}

Belgium lies at the border of two worlds: the great lossic plain in the north, the Ardenne-Eifel Palaeozoic Massif in the south, including many caves. This territory concentrates on a smaller scale the different contexts represented in North-West Europe. Therefore, it generated variability in human behaviour, particularly shown by lithic resource management.

In addition, located in the heart of North-West Europe, Belgium acted as a crossroads, where influences from groups from both Western and Central Europe met and intermingled. 


\section{The Conference}

This meeting is organized within the framework of the event "Archéologie 2014", celebrating the $25^{\text {th }}$ anniversary of the regionalization of archaeology in Belgium. The conference takes place in the "Moulins de Beez", in Namur, on March $20^{\text {th }}-21^{\text {st }}$. It is followed by a fieldtrip to three major Belgian cave sites (Spy, Goyet, Scladina) on March $22^{\text {nd }}$.

This volume includes the abstracts from the 60 contributions presented by 136 authors: 39 podium presentations, 18 posters and 3 presentations of the sites visited during the fieldtrip.

\section{Organizing committee}

- Kévin Di Modica, archaeologist (Scladina)

- Stéphane Pirson, geologist (SPW)

- Michel Toussaint, palaeoanthropologist (SPW)

- Grégory Abrams, zooarchaeologist (Scladina)

- Dominique Bonjean, archaeologist (Scladina)

\section{Scientific committee}

- Pierre Antoine (CNRS, France)

- Nick Ashton (British Museum, UK)

- Pascal Bertran (INRAP, France)

- Pascal Depaepe (INRAP, France)

- Damien Flas (FNRS-ULg, Belgium)

- Paul Haesaerts (RBINS, Belgium)

- Jean-Jacques Hublin (Max Planck Institute, Germany)

- Foni Le Brun-Ricalens (MNHA, Luxemburg)

- Jean-Luc Locht (INRAP, France)
- Marie-Hélène Moncel (CNRS - MNHN, France)

- Marcel Otte (ULg, Belgium)

- Jürgen Richter (Universität zu Köln, Germany)

- Wil Roebroeks (Universiteit Leiden, The Netherlands)

- Veerle Rots (FNRS - ULg, Belgium)

- Patrick Semal (RBINS, Belgium)

- Chris Stringer (Natural History Museum, UK)

- Philip Van Peer (KUL, Belgium)

\section{Acknowledgements}

The organizing committee is grateful to the Public Service of Wallonia for financial and logistical support in the organization of this conference, with special thanks to Marc Schepers and the "cellule events-DGO4". Our thanks go to the cities of Andenne (Scladina Cave), Gesves (Goyet Cave) and Jemeppe-sur-Sambre (Spy Cave) for their great involvement in enhancing the prehistoric heritage. We are also grateful to the Prehistomuseum for welcoming us in the Goyet Cave and the field team of Archéologie Andennaise for welcoming us in Scladina Cave. Finally, a warm "thank you" to Martha Bakara for her help in the edition of the present volume, and to Rebecca Miller and Brad Gravina for their valuable help in checking the English of some abstracts, including the present foreword. 


\section{MIDDLE PALAEOLITHIC IN NORTH-WEST EUROPE}

MULTIDISCIPLINARY APPROACHES

\section{PODIUM PRESENTATIONS}





\section{THE EXPLOITATION OF FAUNAL RESOURCES IN NORTH-WEST EUROPE: UPDATED REVIEW OF THE MAIN SITES}

\section{Grégory Abrams ${ }^{1,2}$, Patrick Auguste ${ }^{3}$, Silvia M. Bello ${ }^{4}$, Sabine Gaudzinski-Windheuser ${ }^{5}$, Mietje Germonpré $^{6}$, Lutz Kindler ${ }^{5}$, Keiko Kitagawa ${ }^{7}$, Petra Krönneck ${ }^{7}$, Susanne Münzel ${ }^{7}$, Simon Parfitt ${ }^{4}$, Geoff M. Smith ${ }^{5}$ \& Thijs van Kolfschoten ${ }^{8}$}

\footnotetext{
${ }^{1}$ Scladina Cave Archaeological Centre, Andenne (Belgium); gregory.abrams@scladina.be

${ }^{2}$ Department of Prehistory, University of Liège, Liège (Belgium)

${ }^{3}$ UMR 8217 CNRS, Université Lille 1, Villeneuve d'Ascq (France)

${ }^{4}$ Department of Earth Sciences, Natural History Museum, London (UK)

${ }^{5}$ MONREPOS Archaeological Research Centre and Museum of Human Behavioural Evolution. Schloss Monrepos, Neuwied (Germany)

${ }^{6}$ Operational Direction "Earth and History of Life", Royal Belgian Institute for Natural Sciences, Brussels (Belgium)

${ }^{7}$ Institut für Naturwissenschaftliche Archäologie - Archäozoologie, Universität Tübingen, Tübingen (Germany)

${ }^{8}$ Faculty of Archaeology, Leiden University, Leiden (The Netherlands)
}

The Middle Palaeolithic has gone through many climate changes where warmer and colder phases alternated. These changes modified the plant cover, fauna who lived in and, consequently, relationships between Neandertals and their environment. This environment was also affected by the topography that includes, for the North-West of Europe, vast plains bordered by valleys incising limestone substrate. The almost continuous occupation of this wide area highlights a great adaptive ability of Neandertals, which is also characteristic of the stone tools productions. They were, indeed, able to cleverly juggle with those parameters to provide a measured response to the constraints encountered.

Despite the diversity of occupations, both from an environmental and a chronological point of view, some recurrences were observed. Anthropogenic marks (cut marks and breaking pattern of long bones), visible on bones, emphasize intensive exploitation of animal resources. Neandertals willingly recovered skin, tong, meat and marrow from their game. These marks are mainly observed on small size (chamois, fallow deer), middle size (red deer, reindeer) and large size (bear, horse, aurochs, bison) mammals. Those recorded on megafaunas and mesofaunas, remain minor evidences, although these faunas were hunted as well. Neandertals have also frequently used the bones as fuel and produced tools made on bone fragments (retouchers).
Nevertheless, some specific behavioural features are highlighted as the favoured exploitation of rupicolous mammals observed logically in the cave assemblages. Enjoying their knowledge of the territory, Neandertals took also advantage of the migration routes across the plains of North-West Europe, focusing their attention on gregarious mammals (horses and reindeer).

The main sites, covering these wide geographical and chronological areas, and the different topographic contexts (open-air sites vs. cave sites) have been selected to illustrate the variability in behavioural features for the Middle Palaeolithic of North-West Europe. 


\title{
UPPER PLEISTOCENE LESS-PALAEOSOLS RECORDS FROM NORTHERN FRANCE IN THE EUROPEAN Context: EnVironmental BaCkground and dating of the Middle Palaeolithic
}

\author{
Pierre Antoine $^{1}$, Sylvie Coutard ${ }^{2,1}$, Émilie Goval ${ }^{2,3}$, David Hérisson ${ }^{2,3}$, Jean-Luc Locht ${ }^{1,2}$, Nick \\ Debenham $^{3}$, Jean-Jacques Bahain ${ }^{4} \&$ Gilles Guérin $^{5}$
}

\author{
${ }^{1}$ UMR 8591 CNRS, Université Paris I, Laboratoire de Géographie Physique, "Environnements quaternaires et géoarchéologie”, \\ Meudon (France); pierre.antoine@cnrs-bellevue.fr \\ 2 INRAP Nord-Picardie, Amiens (France) \\ ${ }^{3}$ Quaternary TL Survey, Nottingham (UK) \\ ${ }^{4}$ UMR 7194 CNRS, Département de Préhistoire, IPH, Paris (France) \\ ${ }^{5}$ GEOTRAC/LSCE, Gif-sur-Yvette (France)
}

In Northern France the loess cover from the Last Glacial (Weichselian) is represented by a subcontinuous cover rising up to 8-9 $\mathrm{m}$ in thickness in the best locations as leeward slopes (E-NE exposition). In this large area, pedostratigraphic sequences from the Last Interglacial-glacial cycle (EemianWeichselian) have been intensely studied, especially in the frame of very active rescue archaeological programs that have provided hundreds of individual sequences from test-pits or excavations. In spite of variations in the thickness of the different stratigraphic units, driven by differences in geomorphological contexts and in location of the profiles regarding to sources of aeolian material, the pedostratigraphic sequences from the last Interglacial-glacial cycle exhibit a particularly constant pedosedimentary pattern including well identified pedological and periglacial marker horizons that can be followed towards the East in Belgium, in Germany and even in Central-Europe.

The main objective of the presentation is to propose a summary of the pedostratigraphic sequence from Northern France and a global correlation scheme with surrounding areas. The great homogeneity that is evidenced in the response of Western European environments to rapid climatic changes provides a solid base for the discussion of relations between man, climate and environment since the Eemian Interglacial. In Northern France, the synthesis of the observations carried out on no more than 80 sequences during the last 20 years allows to draw a highly detailed pedostratigraphic and chronostratigraphic scheme that represents a unique database to discuss the relations between Palaeolithic occupations and environment. This frame can be summarised by the succession of four main chrono-climatic phases that follow the erosion of the interglacial brown leached soil (Eemian) during MIS 5d:

1. Early-glacial (112-72 ky): including a phase with grey forest soils (Early-glacial A: MIS 5a-5d GIS interstadials 21-24) and a phase with steppe-like soils (Early-glacial B: end of MIS 5a GIS 19 \& 20).

2. Lower Pleniglacial ( 70-58 ky): first typical homogeneous lœss deposits marking the first occurrence of typical periglacial conditions.

3. Middle Pleniglacial ( 58-30 ky): intense and short erosive episode (thermokarst)/deposition of thick body of bedded colluviums reworking the whole underlying units/development of a soil, or of a soil complex (Saint-Acheul-Villiers-Adam Complex) during most of MIS 3.

4. Upper Pleniglacial ( $\sim 30-15$ ky): main network of large ice-wedge casts/drastic acceleration of loss sedimentation (mainly between 27 and $22 \mathrm{ky}$ ) including tundra-gley horizons and large Ice wedge casts.

In this context, the data concerning the last climatic cycle (Eemian-Weichselian) show that Human occupation of Northern France was clearly discontinuous, with a clear concentration of remains during the Early-glacial in forest-steppe contexts developed under continental climate. Only a few occupations were attributed to the Lower Pleniglacial and to the course of the MPGL. A total abandon of the region is attested between $\sim 25$ and $\sim 15$ ky mainly during the period of maximal loess deposition. Given these results there appears to be a strong relationship between the intensity of human occupation and the climatic and environmental context. This relationship appears to be conditioned by the relative abundance of large fauna, itself linked to vegetation density, as indicated by the extremely sparse biomass contemporaneous with the UPGL loss. 


\title{
The Early and Late Middle Palaeolithic of Britain COMPared: DEVELOPMENTS IN TECHNOLOGY AND BEHAVIOUR
}

\author{
Nick Ashton ${ }^{1,2}$, Simon Lewis ${ }^{3} \&$ Beccy Scott $^{1}$ \\ ${ }^{1}$ Department of Prehistory \& Europe, British Museum, London (UK); nashton@theBritish Museum.ac.uk \\ ${ }^{2}$ Institute of Archaeology, University College London, London (UK) \\ ${ }^{3}$ School of Geography, Queen Mary University London, London (UK)
}

The British Middle Palaeolithic can be divided into an early phase from c. 250 to $180 \mathrm{ky}$ (MIS 8-7) and a later phase from c. 65 to $40 \mathrm{ky}$ (MIS 3). The apparent absence of human presence during MIS 64 appears to be due to a combination of cold climate and the increasing insularity of Britain during warmer phases. This paper examines the archaeological records from before and after this period of human absence. In particular it compares the nature of the record, the distribution of sites together with the differing technologies and typologies. These differences prompt questions about the changes in human behaviour over this time-span and how this compares to the record from neighbouring mainland Europe. 


\title{
EVOLUTIONS, BIOCHRONOLOGICAL AND PALAEOECOLOGICAL CONTRIBUTIONS OF MAMMAL associations in North-West Europe during the Middle Palaeolithic
}

\author{
Patrick Auguste ${ }^{1}$
}

${ }^{1}$ UMR 8217 CNRS, Université Lille 1, Villeneuve d'Ascq (France); patrick.auguste@univ-lille1.fr

North-West Europe is during the late Middle Pleistocene and the Upper Pleistocene (MIS 8 to 3) a biogeographical crossroads where the direct influence of climate change is particularly marked. The landscapes are changing in correlation with the rhythms of major climate cycles and sometimes seasonal scale, leading consequently to profound modifications in mammalian associations identified in sites in association with Middle Palaeolithic industry. This geographical area is characterized by very different mammalian groups, which allow us to better take in account the effects of climate variability on population dynamics, unlike the more southern regions of Europe where this effect is moderate. Two major types of fauna associations can be met: animals adapted to the temperate humid climates and a landscape of forests and meadows during interglacial periods and interstadial; species adapted to cold and dry continental climate and steppe areas during glacial phases. The associations of macrofaunas, mesofaunas but also mammalian microfaunas identified appear very similar and synchronous in the geographical area concerned, including Northern France, England, Belgium, The Netherlands, Luxembourg and the Rhine western Germany. Many well-dated and coherent ecological contexts sites allow us to follow the evolution of mammalian settlement contemporary with the technological culture of the Middle Palaeolithic. Moreover, these faunas provide an effective biochronological framework and offer very relevant climatic and environmental reconstructions. Recurrent migrations on a massive scale occur in correlation with changes of the parameters of the plant environment and landscape. It is within these dynamic mammal settlements that occurs the Neandertal occupations since the end of the Lower Palaeolithic to the early Upper Palaeolithic. 


\section{Neanderthals of THE ChanNel RiVer VAlley: NEW WORK AT LA COTTE DE ST. BRELADE}

\section{Martin Bates ${ }^{1}$, Richard Bates ${ }^{2}$, Ed Blinkhorn ${ }^{3}$, Chantal Conneller ${ }^{4}$, Clive Gamble ${ }^{5}$, John McNabb Marie-Anne Julien ${ }^{6}$, Matt Pope ${ }^{7}$, Beccy $\operatorname{Scott}^{8}$ \& Andy Shaw ${ }^{5}$}

\footnotetext{
${ }^{1}$ University of Wales Trinity Saint David, Lampeter (UK)

${ }^{2}$ School of Geography and Geosciences, University of St Andrews, St Andrews (UK)

${ }^{3}$ Department of Archaeology, University of York, York (UK)

${ }^{4}$ School of Arts, Languages and Cultures, University of Manchester, Manchester (UK)

${ }^{5}$ Centre for the Archaeology of Human Origins, University of Southampton, Southampton (UK)

${ }^{6}$ Institut für Naturwissenschaftliche Archäologie, Universität Tübingen, Tübingen (Germany)

${ }^{7}$ Institute of Archaeology, University College London, London (UK)

${ }^{8}$ Department of Prehistory \& Europe, British Museum, London (UK); rscott@ theBritish Museum.ac.uk
}

The site of La Cotte de St. Brelade, Jersey, preserves evidence of changing Neandertal adaptations to life on the plains of North-West Europe over at least two glacial-interglacial cycles (220 - 30 ky B.P.). Although widely viewed as a hunting and butchery locale, the lithic assemblage from the site attests to changing use over time. Though now an island, during past cold periods, the regional environment would have been profoundly different; Jersey would have formed a significant upland landform (terrestrial "island") on the southern side of the Channel River Plain. The vast amounts of lithic material discarded by Neandertals throughout the entire La Cotte de St. Brelade sequence suggest that it always remained a pivotal place for them whilst the landscape around it altered profoundly. The material discarded at the site appears largely to have been transported in, thus allowing Neandertal behaviour in the broader landscapes of the Southern Channel River Plain to be "read off" from the material left there.

The environmental complexity recorded within the La Cotte sequence, and the record of shifting climate preserved within the raised beach sequence of the island of Jersey, allows changing behaviour (as reflected by technological change) to be related to the changing structure of this region of the Channel River Plain. In this paper we present new results from reanalysis of the assemblages (lithics and fauna) from throughout the La Cotte sequence, in order to explore how Neandertals were using the site and exploiting its wider landscape. 


\title{
FORMATION PROCESSES OF PALAEOLITHIC SITES: THE ROLE OF NATURAL FACTORS
}

\section{Pascal Bertran ${ }^{1,2}$}

\author{
${ }^{1}$ INRAP Gironde, Pessac (France); pascal.bertran@inrap.fr \\ ${ }^{2}$ UMR 5199 CNRS, Université Bordeaux 1, Laboratoire PACEA, Talence (France)
}

\begin{abstract}
All archaeological sites have undergone modification after abandonment due to biological, geological and pedological processes. Modification ranges from simple oxidation of organic matter to full erosion and redistribution of the remains. Usually, the sites are in an intermediate state of degradation. As a consequence, the aim of the taphonomic analysis is to determine the limits we have to ascribe to the archaeological interpretation, either because of lost of lithic or bone assemblage integrity (weathering, hydraulic sorting...), or because of artefact displacement, or else because of assemblage mixing. Taphonomy appears to be a prerequisite to site investigation through testing the validity of a palaeoethnographic analysis of the spatial distribution of the remains, and checking the potential bias that may affect the techno-economic study of the assemblage. In stratified sites, taphonomy makes it possible to enlighten artefact
\end{abstract}

mixing and, hence, to evaluate the suitability of the assemblages to solve issues about definition and evolution of prehistoric cultures. Geology, palaeontology, and archaeology combine to understand site modification. Comparison between the lines of evidence provided by each discipline allows proposition of a plausible scenario for site history from abandonment by humans to excavation. Analysis rests mainly on actualistic data on modification induced by biological and geological processes. These are derived from experiments in laboratory or natural environments, while study of weathering needs geochemical analysis of the site. In many ways, taphonomy is still a young science, and significant developments are expected to emerge from multiplication of experiments and site studies. Examples of such studies from Middle Palaeolithic sites will be presented here. 


\title{
LITHIC INDUSTRIES FROM THE BEGINNING OF THE WEICHSELIAN AT SAINT-ILLIERS-LA-VILLE (YVelines) ANd THE QUeSTION OF THE Micoquian IN THE PARIS Basin
}

\author{
Frédéric Blaser ${ }^{1}$ \& Christine Chaussé ${ }^{2}$
}

\footnotetext{
${ }^{1}$ INRAP Île-de-France, La Courneuve (France); frederic.blaser@inrap.fr

${ }^{2}$ UMR 8591 CNRS, Université Paris I, Laboratoire de Géographie Physique, "Environnements quaternaires et géoarchéologie”, Meudon (France)
}

Recent excavations at Saint-Illiers-la-Ville (Yvelines) revealed numerous Palaeolithic occupations dated to between 400 and 50 ky B.P. One of the levels (S2N1) contained numerous bifacial artefacts, several of which are similar to examples attributed to the Micoquian by F. Bordes. Stratigraphic studies, as well as a single TL date of $105 \pm 8$ ky B.P., place these occupations at the very beginning of the Early Weichselian. Following the presentation of several typically Middle Palaeolithic chaînes opératoires (core reduction and bifacial shaping) identified by a technological analysis, questions concerning the existence of a chrono-culturally distinct and geographically limited Micoquian facies or a simple case of morpho-technological convergence between very different traditions are discussed.

Several groups of industries were studied, corresponding to different historic moments in the definition of Micoquian. The first comprises sites near Saint-Illiers-la-Ville in the Mantois region (Mantes, Rosny, Rolleboise) studied by F. Bordes and one site from Normandy (Saint-Pierre-lesElbeufs).
The second group corresponds to facies identified and defined in Germany by Bosinski. The last group concerns more recent excavations in the Paris Basin, where new sites and industries (Verrières-le-Buisson, Vinneuf, Villeneuvel'Archevêque) have also been attributed to the Micoquian by various authors. Based on these comparisons, a Seine Basin Micoquian can be defined by its specific geography, cultural and technical traditions, and chronology (MIS 5d). These peculiarities question the continued use of the term "Micoquian" for these assemblages and equally suggest that a general reassessment of the issue is necessary, as has been undertaken in Germany (e.g. Richter, Jöris, etc.). 


\title{
CARbon AND OXYGEN STABLe ISOTOPES $\left({ }^{13} \mathrm{C},{ }^{18} \mathrm{O}\right)$ In TOOTH ENAMEl OF LATE Pleistocene MAMMALS: TOOLS FOR RECONSTRUCTING PALAEOCLIMATE, PALAEOENVIRONMENTS AND palaeodiets during the Middle Palaeolithic
}

\author{
Hervé Bocherens ${ }^{1}$, Grégory Abrams ${ }^{2,3}$, Dominique Bonjean ${ }^{2,3}$, Martin Cotte ${ }^{1}$, Kévin Di Modica ${ }^{2} \&$ \\ Christoph Wißing ${ }^{1}$
}

\footnotetext{
${ }^{1}$ Fachbereich Geowissenschaften, Biogeologie, Universität Tübingen, Tübingen (Germany); herve.bocherens@ uni-tuebingen.de

${ }^{2}$ Scladina Cave Archaeological Centre, Andenne (Belgium)

${ }^{3}$ Department of Prehistory, University of Liège, Liège (Belgium)
}

Bone collagen is the tissue of choice for reconstructing Neandertal diet using carbon $\left({ }^{13} \mathrm{C} /{ }^{12} \mathrm{C}\right)$ and nitrogen $\left({ }^{15} \mathrm{~N} /{ }^{14} \mathrm{~N}\right)$ isotopic composition, and numerous applications of this approach have been performed since more than 20 years. However, the preservation of this protein is exceptional for sites older than 50,000 years, and therefore this approach is unfortunately not applicable to most Middle Palaeolithic sites. In contrast, the carbonate fraction of tooth enamel is extremely stable and usually preserves its isotopic composition for millions of years. The use of carbon and oxygen $\left({ }^{18} \mathrm{O} /{ }^{16} \mathrm{O}\right)$ isotopic composition of mammal tooth enamel to investigate the environment and diet of fossil hominids is widespread in tropical environments, but still very limited in Pleistocene Europe.

We will present here the potential and first results of this approach to expand our knowledge of the palaeobiology of Neandertals in North-West
Europe, using sites with mammal remains deposited under different climatic conditions, such as Scladina Cave, as case studies. This approach is particularly powerful during temperate climatic episodes to decipher the possible use of dense forest environments by prey species hunted by Neandertals. Moreover, it is possible to document seasonal variations of temperature and diet for large herbivores such as horses, rhinoceros or bovids, using serial isotopic analysis of high-crown teeth. This approach also provides indices about mobility patterns of these animals. Finally, the isotopic analysis of Neandertal tooth enamel provides direct information on the average diet of hominins in comparison with the prey available to them and other predators living around them.

These results will be compared to those of other disciplines and we will show how the integration of all available data provides a more accurate picture of human life during the Middle Palaeolithic. 


\section{THE RHEINDAHLIAN}

\section{Gerhard Bosinski ${ }^{1}$}

${ }^{1}$ UMR 5608 CNRS - Laboratoire TRACES, Université de Toulouse le Mirail, Toulouse (France); bosinski@,orange.fr

Several late Middle Palaeolithic sites in NorthWest Europe are characterised by unmodified and retouched blades as well as the lack of typical Middle Palaeolithic tools such as scrapers and Mousterian points. The most important of such sites are Rheindahlen-Westwand, Tönchesberg 2B, and Wallertheim D in the Rhineland, Rocourt in Belgium, Seclin, Riencourt-les-Bapaume, Bettencourt-Saint-Ouen, Etoutteville, and SaintGermain-des-Vaux in Northern France. While broad, flat Levallois flakes were produced from large, convex core surfaces, the reduced size of others effectively limited production to small flakes, including those produced using the Kostenki technique. Retouched artefacts are dominated by marginally and sometimes only partially retouched blades. Currently, distinct 'Aurignacian-type' retouch is only known Wallertheim D, where it was used to produce points. Finally, slightly curved, backed pieces may represent projectiles.

Faunal remains are only preserved in the humic sediments of Tönchesberg (2B) and Wallertheim (D). Horse, aurochs, and deer occur at both sites, while steppe rhino (Dicerorhinus hemitoechus), fallow deer (Dama dama), and wild ass (Equus hydruntinus) were also recovered from Tönchesberg, and lion is only represented at Wallertheim. Interestingly, 110 deer antlers, all shed except one, from Tönchesberg suggest their being collected and introduced to the site. Coldadapted species (reindeer, mammoth, and wolly rhino) are absent. Charcoal from oak and elm indicate a moderate climate, whereas the microfaunal signal (Microtus arvalis, Microtus agrestis) indicates a steppic landscape.
Fire-cracked lithic artefacts and burnt bones and antlers at Tönchesberg demonstrate the presence of hearths. Several small artefact concentrations 400 $m$ from one another in the Rheindahlan seem to indicate that the area was occupied several times. Fortunately there is no cave in that area which would have attracted the settlement and led to a mixture of the different occupations. In terms of the chronology of the Rheindahlan sites, Tönchesberg, Wallertheim, Seclin, and Riencourt-les-Bapaume all date to MIS 5c, with level 2B from Tönchesberg dated more precisely to GI 24. All of these sites therefore predate the MIS 5a (Odderade Interstadial) Keilmesser occupations (Micoquian). 


\title{
THE GREAT FOSSIL MINE OF THE SOUTHERN NORTH SEA: EXPLORING THE POTENTIAL OF SUBMERGED PALAEOLITHIC ARCHAEOLOGY
}

\author{
Rachel Bynoe $^{1}$, Justin Dix ${ }^{1} \&$ Fraser Sturt ${ }^{1}$
}

\footnotetext{
${ }^{1}$ Centre of the Archaeology for Human Origins (CAHO), Department of Archaeology, University of Southampton (UK); rachel.bynoe@soton.ac.uk
}

The archaeological significance of now-submerged Palaeolithic landscapes has been recognised since the early twentieth century, and yet the move from discussing the potential of these areas to actually engaging with the physical record is still only in its infancy. Recent advances in geophysical technologies have certainly played an integral role in the beginnings of this engagement, but the driving force behind the interest in these early landscapes is diverse. Commercial involvement has largely been instigated by serendipitous finds of features, deposits or artefacts with academic interest sparked by the discovery of early Palaeolithic archaeological sites in the foreshore deposits along the East Anglian coastline, as well as significant finds from the Dutch portion of the North Sea. However, regardless of the impetus, an extremely important aspect of these finds lies in their ability to falsify the assumption that successive trans- and regressions over these landscapes would have been entirely destructive to the Palaeolithic record.

Accepting the extant nature of these Palaeolithic deposits makes investigating them a priority, yet despite yielding a prolific faunal resource the UK offshore sector of the southern North Sea has had no broad, systematic audit to identify the potential it holds. Can we therefore begin to utilise this derived record to aid our interpretations of these landscapes and enhance the highly fragmentary terrestrial record? After all, the exclusion of these offshore areas hinders our understanding of the wider Palaeolithic landscape and therefore our interpretations of early hominin life-ways, specifically the early migrations, occupation patterns and environmental preferences that are hinted at by the tantalising finds of Happisburgh 3 and Pakefield.
This doctoral research has collated these specimens, using historical documents to acquire as much information as possible, and, through emerging patterns, is defining their potential. Results have shown significant spatio-temporal patterning at a variety of scales, indicating areas of Palaeolithic potential on the seabed. These patterns, and their implications, will be discussed along with new projects and methods that are working on practically engaging these submerged deposits. 


\title{
CAVE PALYNOLOGY AS A TOOL FOR VEGETATION AND CLIMATE CHANGE RECONSTRUCTIONS DURing THE Middle PAlaEolithic: MYTH OR REAlity?
}

\author{
Mona Court-Picon ${ }^{1}$ \\ ${ }^{1}$ Operational Direction "Earth and History of Life”, Royal Belgian Institute for Natural Sciences, Brussels (Belgium); \\ mcourtpicon@naturalsciences.be
}

Pollen analysis has been, and still is, one of the most widely used techniques in Quaternary sciences, especially to reconstruct vegetation history and climate variability. Fossil deposits of accumulating plants, such as peat sediments, were very early investigated as they are particularly suitable for the reception, storage and conservation of palynomorphs. Thanks to successive methodological innovations, palynological analyses then gradually developed by multiplying studies of diverse more mineral sedimentary materials (lake, stream and/or marine sediments, lœss deposits, travertine, etc.). These new efficient techniques also led to an interest in archaeological sediments, allowing palaeoenvironmental reconstructions where no adequate Quaternary continental sedimentary records are available. Soon after the mid- $20^{\text {th }}$ century, caves and rockshelters became then the favored studied places in karstic areas to approach the environment of prehistoric humans.

However, the pollen record in caves is a complex phenomenon in which multiple geological, biological and atmospheric factors are involved and could lead to some distortions and discontinuities in the pollen assemblages. When not perceived, these pitfalls have sometimes generated some over- or misinterpretations. After a keen interest, cave sediment sequences were thus considered as unattractive, presenting lot of alterations, difficult to correlate and with a low palaeoenvironmental potential. The validity and scope of the interpretation of palynological data from this type of deposits are still highly controversial and debatable. In Belgium, a systematic program of detailed stratigraphic recordings from caves associated with various palaeoenvironmental analyses has recently been undertaken in close collaboration with researchers from different disciplines. The objective was to better understand the sedimentary dynamics of these fillings and to test their potential as recorders of Quaternary climatic variations. In that context, new pollen data from two Belgian caves have been acquired and open new prospects for research work in this type of environments.

In this paper, we present the state of the art of cave palynology, including the different parameters defining pollen taphonomy, the potentials and the limits of pollen analysis on Quaternary cave deposits. Through the examples of Walou and Scladina Caves, we show that good palynological results can be obtained in these contexts. These records are compared and evaluated in the light of multidisciplinary palaeoecological information from these two prehistoric settlements. When precautions are taken and a close link with geology and archaeology is maintained, local environment of the prehistoric populations, but also major trends in vegetation evolution and climate change during the Middle Palaeolithic, can be accurately documented by pollen records from cave sequences. 


\title{
Middle Palaeolithic Plant enVironments in North-WeSt Europe
}

\section{Freddy Damblon ${ }^{1}$}

\author{
${ }^{1}$ Operational Direction "Earth and History of Life", Royal Belgian Institute for Natural Sciences, Brussels (Belgium); \\ Freddy.Damblon@naturalsciences.be
}

The Middle Palaeolithic is generally likened to Mousterian industry used by Neandertal men. This industry has become evident between 350,000 and 300,000 years ago, this time limit still being a matter of debate linked to different kinds of records and dating systems. The transition from Middle to Upper Palaeolithic occurred around 35,000 B.P. with the unset of the Aurignacian industry. During this time period Middle Palaeolithic people gathered and hunted all over vast regions from the Mediterranean to Central Asia and adapted to very different climatic and environmental conditions.

Considering that Pre-Neandertal humans might have appeared around 400,000 years ago, we will take the period 400,000 - 35,000 B.P. into account, i.e. the MIS 11 - MIS 3 time window which includes a succession of 4 interglacial (MIS 11, 9, 7 and 5e) and 4 glacial (MIS 10, 8, 6 and 4-3) periods that were more or less strongly interrupted by short term climate oscillations (cold spells and interstadials).

The reconstruction of the environments in NorthWest Europe, especially plant biomes, is based mainly on palynology and macrofossil analysis, notably wood, charcoal and carpo-remains.
Additional information may be gained from bone, mollusc shells and various kinds of insect remains.

During the interglacial episodes good conditions of temperature and precipitation allowed the sequential development of large forests in NorthWest Europe. On the contrary low temperature and precipitation during glacial periods led to killing temperate trees and favoured open dry biomes like desert-steppe, steppe and forest-steppe while tundra communities could develop locally in wetter biotopes.

Some differences in the composition of the tree and herb flora are detected depending, just like today, on the latitude and the influence of oceanic air masses. Diverse attempts of reconstructing past biomes and mapping their distribution in NorthWest Europe during the last Glacial and Interglacial cycle are presently in progress as well as reconstructing the variations of some climatic factors such as temperature, precipitation or moisture availability on the continent. This may lead to better understand the conditions of life of Palaeolithic men but also the mechanism of climate changes in the course of the Quaternary. 


\title{
NEANDERTHAL OCCUPATIONS AND LAND USE IN KARSTIC ENVIRONMENTS FROM SOUTHERN BelgiUm AND SOUTh-EASTERn France duRING The EARLy UPPER Pleistocene: REGIONAL OR COMMON FEATURES?
}

\author{
Camille Daujeard $^{1}$, Grégory Abrams $^{2,3}$ \& Mietje Germonpré ${ }^{4}$
}

\author{
${ }^{1}$ UMR 7194 CNRS, Département de Préhistoire, IPH, Paris (France); camilledaujeard@hotmail.fr \\ ${ }^{2}$ Scladina Cave Archaeological Centre, Andenne (Belgium) \\ ${ }^{3}$ Department of Prehistory, University of Liège, Liège (Belgium) \\ ${ }^{4}$ Operational Direction "Earth and History of Life", Royal Belgian Institute for Natural Sciences, Brussels (Belgium)
}

Karstic systems, by their natural features, have preserved an abundant archaeological documentation, where faunal remains are well represented. This particular environment has been intensely exploited and occupied by Neandertal groups in many various areas and was conductive to the presence of rocky ungulates. We focus here on the beginning of the last glacial period, which is characterized by a high climatic variability where colder environments alternated with other more temperate and a great population density.

The Ardèche region in South-Eastern France and the Meuse basin in Belgium have been recently the subjects of regional studies crossing archaeological, geological and chronological data in order to clarify human land-use and subsistence strategies. These two areas offer multiple rock- shelters and caves with archaeological layers dated from MIS 5 to 3 . They were all visited by a great variety of inhabitants: Neandertals as well as small, medium and large carnivores. Each of these habitats is specific by its topography and type of human occupation but all reveal a great homogeneity of behaviour within their sequence.

By comparing data coming from faunal accumulations in these two related areas distant by a thousand kilometers, we attempt to have a better view of the underlying motivations behind Neandertal type of occupations of karstic networks during the early Upper Pleistocene. Do regional features of land-use exist in varied locality of Northern and Southern Europe or can we perceive common ways of environmental exploitation strategies? 


\section{THE COLONISATION OF WESTERN EUROPE: COARSE AND FINE-GRAINED PERSPECTIVES}

\section{Pascal Depaepe \& Wil Roebroeks}

${ }^{1}$ INRAP Nord-Picardie, Amiens (France)

${ }^{2}$ Faculty of Archaeology, Leiden University, Leiden (The Netherlands)

Hominin occupation of Western Europe started more than one million years ago, but until the earlier part of the Middle Pleistocene occupation seems to have been intermittent and mostly limited to southern areas, with some northern excursions though, such as into what is now England at the very end of the Lower Pleistocene (Happisburgh 3). From about half a million years ago hominin presence seems to have become more substantial, though still limited to areas below $54^{\circ}$ degrees North during the late Middle Palaeolithic.
In this presentation we will briefly discuss the distribution of Lower and Middle Palaeolithic sites in time and space, and the issues at stake in the establishment of solid distribution patterns, such as large scale taphonomical issues as well as dating problems. We will also try to interpret these spatiotemporal distribution patterns into inferences about habitat preferences of Neandertals, and suggest some possibilities for future integration of archaeological data with genetic studies of Neandertals. 


\title{
The Middle Palaeolithic of BelgiUm: CRITICAL REVIEW OF THE DATASET, GLOBAL OVERVIEW AND PROSPECTS
}

\author{
Kévin Di Modica ${ }^{1}$, Stéphane Pirson ${ }^{2}$, Grégory Abrams ${ }^{1,3} \&$ Michel Toussaint ${ }^{2}$
}

\footnotetext{
${ }^{1}$ Scladina Cave Archaeological Centre, Andenne (Belgium)

${ }^{2}$ Direction of Archaeology, Public Service of Wallonia, Namur (Belgium)

${ }^{3}$ Department of Prehistory, University of Liège, Liège (Belgium)
}

In Belgium, prehistoric research began as early as 1829. For decades until the First World War, the country was captivated by Prehistory, with scientific programs developed mainly on the karstic environment of the Meuse Valley and in the fluviatile and lœssic contexts of the Haine Basin. In addition, many researchers and surveyors documented a large number of Middle Palaeolithic sites. Most of the data now available in Belgium for the Lower and Middle Palaeolithic result from this intense activity during the $19^{\text {th }}$ and early $20^{\text {th }}$ century. The discoveries of Neandertal remains by PhilippeCharles Schmerling at Engis (1829-1830), Édouard Dupont at La Naulette (1866), Marcel De Puydt and Max Lohest at Spy (1886), or even Ferdinand Tihon at Fond-de-Forêt (1895) are seen as highlights punctuating the intense research activity during this time.

During the interwar period, prehistoric research decreased and it was not until the mid-1950s that one sees interest increasing in Palaeolithic research. Since that time, activities of researchers, mainly from the Royal Belgian Institute of Natural Sciences, the University of Liège and more recently the Public Service of Wallonia, led to the collection of more limited but better documented multidisciplinary field data concerning the Lower and Middle Palaeolithic. In the meantime, private researchers continued to document Lower and Middle Palaeolithic findings throughout Belgium. Since the 1970 s, several syntheses of the Lower and Middle Palaeolithic periods have been published.

Almost two centuries of prehistoric research have led to the accumulation of an impressive set of documentation: over 437 find spots from different environmental contexts, of which 46 are in caves, 24 include faunal data and 8 have yielded human remains. Exploitable information about their chronological position and/or palaeoenvironmental context is available for 26 cases.

On the one hand, this dataset is quantitatively rich and comprises various kinds of data, including stratigraphic records, radiometric dates, landscape occupation, lithic industries, fauna and human remains. On the other hand, most of this dataset is of poor quality as it resulted from old excavations, surface collecting and activities of amateur archaeologists. Consequently, only the few sites excavated in the last 30 years appear to have been sufficiently documented to allow a multidisciplinary approach leading to the reconstruction of human behaviour, chronology and palaeoenvironmental context at the scale of site.

This balanced assessment implies that when using Middle Palaeolithic data from Belgium, the historical background of prehistoric research in the country should be taken into account. Each of the find spots can still provide information to help reconstruct past human behaviour, but this depends on the issue examined and the scale of resolution adopted.

In the last few years, archaeological syntheses have already enabled a critical review of the chronological context of Middle Palaeolithic occupations (Pirson \& Di Modica, 2011) and addressing lithic raw material management at the scale of territory (Di Modica, 2010) by using data from recent/current fieldworks and old collections. In terms of anthropology, review of old collections such as Goyet and Spy (Rougier \& Semal, 2013, 2014 [in press]) and studies of recently excavated fossils (Couvin: Toussaint et al., 2010; Walou: Draily et al., 2011; Scladina: Toussaint \& Bonjean, 2014 [in press]) have provided interesting results and complete the panorama on Mosan Neandertals (Toussaint et al., 2011). In terms of faunal and zooarchaeological data, an overall work of 
revision is in progress that should lead to a regional synthesis; it has recently begun to provide data (Abrams et al., 2013).

In the near future, insights into old collections should be continued. Recently obtained results for Spy (Semal et al., this volume) and Goyet Caves (Rougier et al., this volume) have demonstrated, if necessary, the immense potential of these collections if they are studied critically. Ongoing excavation programs will be continued in order to refine the chronological and palaeoenvironmental context of Middle Palaeolithic occupations.

Despite all of this, it is now time to develop a new research program taking into account the whole issue of Lower and Middle Palaeolithic occupation in Belgium and integrating the results obtained these last few years in an encompassing and multidisciplinary prospect.
Recent and current syntheses have raised new questions in terms of chronology, palaeoenvironment, landscape management, resource exploitation and cultural aspects that could be approached by such a program. Therefore, new excavations on Palaeolithic sites are required, not only in the framework of preventive archaeology, but also on the basis of recently raised questions tending toward a regional approach to Neandertal occupations as part of the wider issue of the Middle Palaeolithic in North-West Europe.

\section{References}

Abrams G., Bello S. M., Di Modica K., Pirson S. \& Bonjean D., [in press]. When Neanderthals used cave bear (Ursus spelaeus) remains: Bone retouchers from unit 5 of Scladina Cave (Belgium). Quaternary International.

Di Modica K., 2010. Les productions lithiques du Paléolithique moyen de Belgique: variabilité des systèmes d'acquisition et des technologies en réponse à une mosaïque d'environnements contrastés. Ph.D. Dissertation, Université de Liège - Museum National d'Histoire Naturelle, $787 \mathrm{p}$.

Draily, C., Pirson, S. \& Toussaint, M. (Eds), 2011. La grotte Walou à Trooz (Belgique). Fouilles de 1996 à 2004. Volume 2, Les sciences de la vie et les datations (Études et Documents - Archéologie, 21): 242 p.

PIRSON S. \& Di ModicA K., 2011 Position chronostratigraphique des productions lithiques du Paléolithique ancien en Belgique: un état de la question. In: Toussaint M., Di Modica K. \& Pirson S. (Dir.), Le Paléolithique moyen en Belgique. Mélanges Marguerite Ulrix-Closset (ERAUL 128, Bulletin des Chercheurs de la Wallonie Hors-série No 4): 105-148.

Rougier H. \& Semal P. (Eds), 2013. Spy Cave. 125 years of multidisciplinary research at the Betche aux Rotches (Jemeppe-surSambre, Province of Namur, Belgium). Volume 1 (Anthropologica et Praehistorica 123), 386 p.

ROUGIER H. \& SEMAL P. (Eds), 2014 [in press]. Spy Cave. 125 years of multidisciplinary research at the Betche aux Rotches (Jemeppesur-Sambre, Province of Namur, Belgium). Volume 2 (Anthropologica et Praehistorica 124).

TOUSSAINT M. \& BonJEAn D. (Dir.), 2014 [in press]. The Juvenile Neandertal Remains from Scladina Cave (ERAUL 134).

Toussaint M., OlejniczaK A. J., El ZaAtari S., Cattelain P., Flas D., LetourneuX C. \& Pirson S., 2010. The Neandertal lower right deciduous second molar from Trou de l'Abîme at Couvin, Belgium. Journal of Human Evolution, 58: 56-67.

Toussaint M., Semal P. \& Pirson S., 2011 Les Néandertaliens du Bassin mosan belge: bilan 2006-2011. In: Toussaint M., Di Modica K. \& Pirson S. (Dir.), Le Paléolithique moyen en Belgique. Mélanges Marguerite Ulrix-Closset (ERAUL 128, Bulletin des Chercheurs de la Wallonie Hors-série No 4): 105-148. 


\section{The LAST Neandertals IN NORTH-WeSt EUROPE AND THE LiNCOMBIAN-RANISIAN- JERZMANOWICIAN}

\section{Damien Flas $^{1}$}

${ }^{1}$ FNRS, Department of Prehistory, University of Liège, Liège (Belgium); damienflas@yahoo.com

The Middle to Upper Palaeolithic transition is still a highly debated topic as it concerns several important questions: the timing and cause of the disappearance of the Neandertal population/dispersal of anatomically modern humans, the cause of the appearance or widespread adoption of certain technical and symbolic behaviours, the role of "transitional industries" during this period and their association with the different biological populations.
In recent years, reappraisal of old collections, new discoveries and new radiocarbon dates have provided new data that enable a more precise interpretation of the Middle to Upper Palaeolithic transition in North-West Europe. This talk will provide an up-to-date synthesis for this period and will tackle related issues, even if North-West Europe remains still poorly known compared to other European areas. 


\title{
Palaeolithic Land USe in DUtCh ANd Belgian Limburg, InTEgrating ARTefact ASSEMblage Data from Upland Open Air Sites
}

\author{
Phil Glauberman ${ }^{1,2}$
}

\footnotetext{
${ }^{1}$ University of Connecticut, Storrs (USA); philip.glauberman@uconn.edu

${ }^{2}$ Middle East Technical University, Ankara, Turkey
}

Determining long-term regional patterns of hominin land use during the Palaeolithic is of utmost importance for investigating behavioural and technological evolution in North-West Europe. Even though the Palaeolithic archaeological database is rich in that region, it is biased towards evidence originating in caves, rockshelters, and fluvial or littoral settings. At the same time, the most prevalent and often ignored evidence for Palaeolithic regional occupation in North-West Europe is found in upland, near-surface lithic assemblages. Integrating lithic technological data from the uplands of river catchments is necessary to complement this unbalanced picture of land use. Recent analysis of samples of 9 upland, surface lithic assemblages $(\mathrm{n}$ artefacts $=2885)$ from the case study region of Dutch and Belgian Limburg yielded a dataset suitable for comparison and integration with extant data from the lower elevation parts of the landscape. Informative indicators of regional mobility patterns and differential land use are the inter-site fragmentation of core reduction sequences and differential artefact discard patterns. Techno-typological analysis of upland palimpsest assemblages yielded robust patterns of differential use of core reduction methods, where discoidal core reduction is more associated with locally complete sequences and Levallois core reduction sequences were more commonly fragmented. Analysis and comparison of artefact class diversity among upland and lowland assemblages indicate differences in site occupational frequency. When considered alongside traditional techno-typological data, these results point to the presence of 'central places' in the uplands that were frequently re-occupied for a variety of purposes, whereas lowland sites in fluvial settings appear to have been occupied infrequently and for specific tasks.

Results of this research demonstrate that systematic analysis of Palaeolithic palimpsest assemblages from upland open air sites yields informative data that can be integrated with those from other parts of the landscape to investigate long-term regional land use behaviours. 


\title{
The point during the Middle Palaeolithic: REFLECTION OF A SPECIFIC STATUS IN NEANDERTHAL HUNTING EQUIPMENT AND TOOLKITS
}

\author{
Émilie Goval ${ }^{1,2}$, David Hérisson2 ${ }^{1,4}$, Jean-Luc Locht ${ }^{1,3}$ \& Aude Coudenneau ${ }^{5}$
}

\author{
${ }^{1}$ INRAP Nord-Picardie, Amiens (France); emilie.goval@inrap.fr \\ ${ }^{2}$ UMR 7194 CNRS, Département de Préhistoire, IPH, Paris (France) \\ ${ }^{3}$ UMR 8591 CNRS, Université Paris I, Laboratoire de Géographie Physique, "Environnements quaternaires et géoarchéologie", \\ Meudon (France) \\ ${ }^{4}$ INRAP CSNE, Croix Moligneaux (France) \\ ${ }^{5}$ UMR 6636 CNRS, LAMPEA, Aix-Marseille Université, Aix-en-Provence (France)
}

During the course of the Middle Palaeolithic, Neandertals produced flakes, blades and points according to wide-ranging operative schemas. Previous research carried out in the north of France has shown the unique aspect of the laminar phenomenon (Révillion, 1994; Locht et al., 2002; Locht et al., 2010), but studies focusing on point production remained rare until recently. However, new studies have shown that the point was not just an anecdotal element of the Neandertal toolkit, as was generally considered for a long time, but that it was associated with a specific status for these populations (Knecht, 1997; Soressi \& Locht, 2010; Goval, 2012; Hérisson, 2012).

Although it is universally accepted that Neandertal Man was capable of hunting large herbivores for food supplies, hunting techniques and tools are often largely unexplained. To date, it is difficult to accurately identify the weapons used for hunting, although hafting and impact marks on points show that this tool must have been part of the hunting equipment (Boeda et al., 1996; Plisson \& Beyries, 1998). Other use wear analyses indicate that the point was handheld, like a knife (with the pointed end serving as an apex). The status of the point thus remains enigmatic as the quantity and production methods of these tools vary hugely from site to site. In the north of France, points are produced and/or brought into the production, kill or processing sites by Man, but this phenomenon appears to be limited to certain specific geographic zones.

The chronological scope of this communication is the Middle Palaeolithic, from the earliest to the most recent phase, encompassing human occupations from the Saalian to the Early Weichselian (from 300,000 B.P. to 70,000 B.P.). This chronological choice stems from the absence of points in the assemblages in the north of France after isotopic stage 4 .

This communication focuses on the point as an element of the toolkit of these populations, but also on the production, the function, the mobility and the representation of this object, or, in other words, on its status.

\section{References}

BoËda E., Connan J., Dessort D., Muhesen S., Mercier N., Valladas H., Tisnérat N., 1996. Bitumen as a hafting material on Middle Palaeolithic artefacts. Nature, 380: 336-338.

Goval É., 2012. Peuplements néandertaliens dans le Nord de la France: territoires, industries lithiques et occupations humaines durant la phase récente du Paléolithique moyen, $312 \mathrm{p}$.

HÉRISSON D., 2012. Étude des comportements des premiers Néandertaliens du Nord de la France. Les occupations saaliennes des gisements de Biache-Saint-Vaast et de Therdonne, Ph.D. Dissertation, Université de Lille, 504 p.

KNECHT H. (Ed), 1997 - Projectile Technology, 408 p.

Locht J.-L. (Dir.), 2002. Bettencourt-Saint-Ouen (Somme): cinq occupations au début de la dernière glaciation (Documents d'archéologie française 90), $168 \mathrm{p}$.

Locht J.-L., Goval É., Antoine P., 2010. Reconstructing Middle Palaeolithic hominid behaviour during OIS 5 in northern France. In: Conard N. J. \& Delagne A. (Eds), Settlement Dynamics of the Middle Paleolithic and Middle Stone Age, vol. 3: 329-356.

Plisson H., Beyries S., 1998. Pointes ou outils triangulaires ? Données fonctionnelles dans le Moustérien levantin. Paléorient, 24 (1): 5-24.

RÉviLLION S., 1994. Les industries laminaires du Paléolithique moyen en Europe septentrionale: l'exemple des gisements de SaintGermain-des-Vaux / Port-Racine (Manche), Seclin (Nord), et de Riencourt-lès-Bapaume (Pasde- Calais) (Publications du CERP 5), $187 \mathrm{p}$.

SORESSI M., LOCHT J.-L., 2010. Les armes de chasse de Néandertal, première analyse des pointes moustériennes d'Angé. Archéopages, 28: 7-11. 


\title{
Chronostratigraphic CONTEXt OF Middle Palaeolithic in the less SEQuences FROM BELGIUM
}

\section{Paul Haesaerts ${ }^{1}$}

\begin{abstract}
${ }^{1}$ Operational Direction "Earth and History of Life", Royal Belgian Institute for Natural Sciences, Brussels (Belgium); paul.haesaerts@naturalsciences.be
\end{abstract}

Stratigraphic records conducted during the last decade in Belgium have increased the consistency of the lœss-palaeosol sequences related to Middle Palaeolithic occurrences. This approach rests on a high-resolution succession of reproducible pedological events reinforced by specific sedimentary markers, the chronological background of the system being fixed by a set of consistent luminescence dates on aeolian deposits. These sequences encompass a complex succession of episodes of soil development ranging from brown forest soil with B2t horizon or chernozem like soil, to weak humic soils, demonstrating the predominance of highly unstable environmental conditions at the scale of North-West Europe. The lœss-palaeosol sequences were further extended to the Central and East European lœss belt, where complementary data combining palynology and malacology show a consistent signature of the vegetation, from broad-leaved forest to dry steppe, with regard to the pedosedimentary records. This allows for the first time to correlate vegetation development phases of the Upper Pleistocene lœsspalaeosol sequences with those of long lacustrine reference pollen sequences of Europe, as well as with the marine and Greenland records. 


\title{
The Emergence of Middle Palaeolithic in Western Europe
}

\author{
David Hérisson $^{1,2}$, Nick Ashton ${ }^{3,4}$, Laurence Bourguignon ${ }^{5}$, Michel Brenet ${ }^{5}$, Dominique Cliquet ${ }^{6,7}$, \\ Kévin Di Modica $^{8}$, Jean-Philippe Faivre ${ }^{9}$, Jean-Luc Locht ${ }^{10,11}$, Marie-Hélène Moncel ${ }^{12}$, Matt Pope ${ }^{13}$, \\ Wil Roebroeks ${ }^{14}$, Beccy Scott ${ }^{3}$, Alain Turq ${ }^{9,15}$, Ann Van Baelen ${ }^{16} \&$ Philip Van Peer ${ }^{16}$
}

\author{
${ }^{1}$ INRAP CSNE, Croix-Moligneaux (France); david.herisson@,inrap.fr \\ ${ }^{2}$ UMR 7194 CNRS, Département de Préhistoire, IPH, Paris (France) \\ ${ }^{3}$ Department of Prehistory \& Europe, British Museum, London (UK) \\ ${ }^{4}$ Institute of Archaeology, University College London, London (UK) \\ ${ }^{5}$ INRAP, Pôle mixte de recherche archéologique de Campagne (France) \\ ${ }^{6}$ UMR 6566 CNRS, Université de Rennes I, CReAAH, Rennes (France) \\ ${ }^{7}$ Service régional de l'archéologie de Basse-Normandie, Caen (France) \\ ${ }^{8}$ Scladina Cave Archaeological Centre, Andenne (Belgium) \\ ${ }^{9}$ UMR 5199 CNRS, Université Bordeaux 1, Laboratoire PACEA, Talence (France) \\ ${ }^{10}$ INRAP Nord-Picardie, Amiens (France) \\ ${ }^{11}$ UMR 8591 CNRS, Université Paris I, Laboratoire de Géographie Physique, "Environnements quaternaires et géoarchéologie", \\ Meudon (France) \\ ${ }^{12}$ UMR 7194 CNRS, Département de Préhistoire, IPH, Paris (France) \\ ${ }^{13}$ Institute of Archaeology, University College London, London (UK) \\ ${ }^{14}$ Faculty of Archaeology, Leiden University (The Netherlands) \\ ${ }^{15}$ Musée National de Préhistoire des Eyzies, Les Eyzies (France) \\ ${ }^{16}$ Prehistoric Archaeology Unit, University of Leuven, Leuven (Belgium)
}

The transition from Lower Palaeolithic to Middle Palaeolithic is one of the most debated questions in early Prehistory since the mid- $20^{\text {th }}$ century. These debates are mostly due to how early prehistorians constructed their chronological model based on index-fossil, model with "artifical boundaries designed to provide structure to a complex record and, rather than being conceived of as permanent or real, should be frequently examined and revised (Roebroeks \& Corbey 2001; Monnier, 2006). In this paper we do not focus our efforts on insolvent issues of systematics and nomenclature. We suggest documenting a time frame known for rapid behavioural and technological changes, from MIS 9 to 6. On a large scale, the Western Europe, several researchers working on principle sites of this period propose to make an assesment of the current research on the emergence of the so-called Middle Palaelolithic. From a rich corpus of archaeological sites, will be discussed in particular the taphonomy, the preservation, the chronology and the environnement of human occupations during MIS 9 to 6 in Western Europe. The question of technological changes in lithic assemblages will also be investigated. After this overview of the current research on the emergence of Middle Palaeolithic, we try to define future research directions to progress on this key-period of Human evolution.

\section{References}

Monnier G. F., 2006. The Lower/Middle Paleolithic Periodization in Western Europe. An Evaluation. Current Anthropology, 47 (5): 709-744.

Roebroeks W. \& Corbey R., 2001. Biases and double standards in palaeoanthropology. In: Corbey R. \& Roebroeks W. (Eds), Studying human origins: Disciplinary history and epistemology (Amsterdam Archaeological Studies 6): 67-76. 


\title{
Pleistocene RHINe-THAMES LANDSCAPES: GEOLOGICAL BACKGROUND FOR HOMININ OCCUPATION OF THE SOUTHERN NORTH SEA REGION
}

\author{
Marc Hijma $^{1,2}$, Kim Cohen ${ }^{2,3,4}$, Wil Roebroeks ${ }^{1}$, Wim Westerhoff ${ }^{4}$ \& Freek Busschers ${ }^{4}$
}

\author{
${ }^{1}$ Faculty of Archaeology, Leiden University (The Netherlands); marc.hijma@deltares.nl \\ ${ }^{2}$ Deltares (The Netherlands) \\ ${ }^{3}$ Utrecht University, Utrecht (The Netherlands) \\ ${ }^{4}$ TNO Geological Survey of The Netherlands (The Netherlands)
}

Geological and archaeological evidences show that large parts of the southern North Sea were dry land during most of the last one million years. The region was part of a flood-basin environment of the Rhine-Meuse system, Thames and Scheldt rivers and bounded by higher Tertiary and Mesozoic topography towards the south. As such it formed an ideal environment for animals and also hominins. This is testified by the significant number of archaeological findings, especially in the last decades as a result of large-scale sand extraction for infrastructural purposes. However, many challenges remain, both on the geological as on the archaeological front, to place those findings in a proper context. This presentation revolves around the challenge of understanding the complex evolution of the southern North Sea in the last million years and the implications for archaeology.

Before the middle part of the Middle Pleistocene a landbridge existed between England and Belgium, even during marine highstands. Since then, the topographical high that separated the palaeo Channel from the North Sea during highstands, started to erode. This erosion culminated in the development of a (combined) axial Rhine-Thames river system during the late Saalian and Weichselian lowstands and formation of a marine connection between the Channel area and North Sea during the Last Interglacial (Eemian, Ipswichian) and the Holocene.

This major change in configuration had strong impacts on:

1. Possible migration routes of herds of herbivores as well as hominins preying upon them.

2. The erosion base of axial and tributary rivers causing an increase in the availability of flint raw materials.

3. Conditions for lœss accumulation in northern France and Belgium and the resulting preservation of Middle Palaeolithic sites.

In this presentation we illustrate these landscape changes by a number of palaeogeographical (scenario) maps and cross sections for some critical periods of North Sea landscape evolution. These form the context for archaeological and palaeontological finds. However, several aspects of the evolution are still debated. Combined archaeological and geological research is needed to resolve the remaining issues. 


\title{
HOW MUCH NEANDERTAL IS IN US?
}

\author{
Jean-Jacques Hublin 1 \\ ${ }^{1}$ Department of Human Evolution, Max Planck Institute for Evolutionary Anthropology, Leipzig (Germany); hublin@eva.mpg.de
}

In the past decade, palaeogenetic studies have shed new light on the nature of the archaic populations who were present in Eurasia before the arrival of modern humans, at the dawn of the Upper Palaeolithic, and have also provided insight into the conditions of replacement of these groups by modern populations. In particular, palaeogenetic studies have quantified the level of gene flow that occurred between different groups (Prüfer et al. 2014) as well as the likely age of these introgression events (Sankararaman et al. 2012). These advancements have 27 uelled a considerable interest in the scientific community as well as in the media, especially regarding the significance of the gene flow that could have occurred between groups. However, in several instances evidence for introgression between groups have been overinterpreted, with some suggesting that it falsifies the widely accepted Recent African Origin (RAO) model for modern human origins and/or the validity of palaeontological taxa. As a matter of fact, in extant non-African individuals only an average of circa $2 \%$ of DNA is believed to be inherited from Neandertals (Meyer et al. 2012). Therefore, the replacement model still stands even if a very low level of gene flow has been detected. From a taxonomical point of view it is important to underline that gene flow between closely related species is a rather trivial phenomenon among mammals. Furthermore although the time of separation between Neandertals and our direct ancestors was relatively short (in geological terms), these groups seem to have been already on the fringe of biological incompatibility at the time of their encounter (Sankararaman et al 2014). Finally recent investigations have provided more information on the expression (or lack of expression) in the phenotype of the introgressed archaic genetic material in extant humans. They also highlight the selective forces that might have affected the populations involved in these processes. Most importantly these studies underpin genetic mutations unique to modern humans which took place in our recent evolution (Meyer et al. 2012).

\section{References}

Meyer M., Kircher M., Gansauge M.-T., Li H., Racimo F., Mallick S., Schraiber J.G., Jay F., Prüfer K., De Filippo C. et al., 2012. A High-Coverage Genome Sequence from an Archaic Denisovan Individual. Science, 338 (6104): 222-226.

Prüfer K., Racimo F., Patterson N., Jay F., Sankararaman S., Sawyer S., Heinze A., Renaud G., Sudmant P.H., De Filippo C. et al., 2014. The complete genome sequence of a Neanderthal from the Altai Mountains. Nature, 505 (7481): 43-49.

Sankararaman S., Patterson N., Li H., PÄÄBo S. \& Reich D., 2012. The Date of Interbreeding between Neandertals and Modern Humans. PloS Genetics, 8 (10).

Sankararaman S., Mallick S., Dannemann M., Prufer K., Kelso J., PäÄвo S., Patterson N. \& Reich D., 2014. The genomic landscape of Neanderthal ancestry in present-day humans. Nature advance online publication. 


\title{
The Middle Palaeolithic of The Middle Moselle Basin: AVAILABLE INFORMATION FROM LUXEMBOURG AND SURROUNDING AREAS
}

\author{
Foni Le Brun-Ricalens ${ }^{1}$
}

${ }^{1}$ Musée National d'Histoire et d'Art, Section Préhistoire, Luxembourg (Grand-Duché de Luxembourg); foni.le brun@me.com

Information concerning the Middle Palaeolithic from the middle Moselle Basin in general, and Luxembourg in particular, remains relatively sparse despite numerous surface finds. Currently, no chronostratigraphic reference sequences for the Early and Late Wechselian Pleniglacial are known in Luxembourg or the immediately surrounding areas. River basins or plateau contexts, for the most part composed of sandstone and heavily eroded, have failed to produce open-air sedimentary profiles, lœssic or otherwise. Moreover, stratified and undisturbed Pleistocene material is still unknown from fluviatile sequences or underground deposits. The rare stratified artefacts that have been recorded are from secondary contexts reworked by erosion processes or solifluxion.

When compared with the lack of qualitative data from in situ Palaeolithic contexts, there appears an overrepresentation of lithic artefacts recovered from surface surveys, particularly on high terraces and plateaus. In fact, in the region considered here, Middle Palaeolithic industries have essentially been documented from open-air sites over the last 40 years thanks to the efforts of amateur prospectors. It is difficult, if not dangerous, to propose a chrono-cultural attribution for these isolated artefacts and assemblages which, while well inventoried and mapped, were found out of context. Despite this lack of stratified contexts, several observations can be made in terms of general 'tendencies' concerning lithic technotypology, particularly in regards to the acquisition and circulation of raw materials as well as mobility strategies. Located between the primary massifs of the Ardenne-Eifel to the north-west and Hunsrück to the east, the Moselle corridor appears as a region with diverse opportunities for broader studies of human behaviour between the Mosan and Rhine Basins. The spatial distribution of the numerous Mousterian sites combined with the identification of several exotic siliceous raw materials transported over intermediate distances provide evidence for occupations and displacements adapted to the resources available in the Moselle corridor.

In terms of lithology, it is interesting to note that the majority of the documented artefacts are made on quartzite cobbles and regional/local quartz. In this "Quarzitprovinz" (Bosinski, 1967), several assemblages include tools manufactured on chaille or flint blanks. This is particularly the case in the south of the region considered (the zone closest to the Lorraine flint outcrops), while to the north the proportion of quartz increases (Löhr et al. 1990). Techno-typologically, the most representative assemblages (Hellange, Lellig, Mertzig) portray a mix of Discoid (dominant?) and Levallois (lesser proportions) at the same site, although in the absence of stratified assemblages it is impossible to establish whether (or not) they are contemporaneous. Raw material constraints (quartz and quartzite) appear to explain a large part of the documented typological convergence, essentially in regards to the Quina Mousterian as well as the predominant use of the Discoid method.

Faced with the difficulty of placing them in the north European context, these industries are ultimately compared with the several chronostratigraphic frameworks available from the Rhine (Germany), Mosan (Belgium), and Paris (France) Basins. In this context, although the fairly substantial presence of small bifaces in certain assemblages in Moselle Basin remains to be explained, it is suggested, with some cautions and without being able to add more precision to the types of techno-complexes in question, that these assemblages represent some final Mousterian expressions from the beginning of the Middle Wechselian Pleniglacial between MIS 4 and 3.

\section{References}

BosinSKI, G., 1967. Die mittelpaläolitischen Funde in westlichen Mitteleuropa, 205 p.

LÖHR H., LIPINSKI E., Koch I., MAY P. (Dir), 1990, Steinzeit im Gerolsteiner Raum, 73 p. 


\title{
THE DisCOID TECHNO-COMPLEX (MIS 3) AT ORMESSON AND ACROSS THE PARIS SEDIMENTARY BASIN: CONSISTENCY AND FLEXIBILITY OF A SINGULAR TECHNICAL CHOICE WITH RELATION TO THE LITHOLOGICAL CONTEXT
}

\author{
Mathieu Leroyer ${ }^{1}$, Pierre Bodu $^{1}$, Hélène Salomon $^{2}$ \& Vincent Lhomme ${ }^{3}$
}

\author{
${ }^{1}$ UMR 7041 CNRS, Maison René-Gionouvès, archéologie et ethnologie, universités Paris Ouest Nanterre La Défense et Paris 1 \\ Panthéon-Sorbonne, Nanterre (France); mathieu.leroyer@mae.u-paris10.fr \\ 2 Department of Prehistory, University of Liège, Liège (Belgium) \\ ${ }^{3}$ INRAP Poitou-Charentes, Bègles (France)
}

During the last decade new excavations and reexaminations of old collection have refreshed our vision of the end of the Middle Palaeolithic. Among those advances, the identification of a "Discoid techno-complex" during the MIS 3 interpleniglacial event, which differs deeply with other sub-contemporaneous technological practices, reinforce the idea that this period witnessed distinct stone knapping traditions. However, such claims must be established within different geographical and lithological context, in order to invalidate more parsimonious explanations of technical variability. The newly excavated openair camp site in Ormesson has provided multiple well preserved archaeological layers. The older is dominated by Discoid flaking method and dates to the MIS 3. These occupations took place in a geographical context where flint is not present in situ but was easily available from different sources within the "daily range" of the site. For instance Gravettian and Châtelperronian have preferentially used Campanian flint available $5 \mathrm{~km}$ from the site along the Loing River. So far the lithic chaînes opératoires in the Discoid Mousterian layer are characterised by a more limited technical involvement both in term of flint procurement (lower flint quality) and knapping gesture. At the same time, the Neandertal occupants invested considerable effort to extract, import and select the raw ochreous material, whose numerous remains have been found associated with stone tool in the Layer 4 . The fact that they did not take advantage of the same trips not only for ochre but also for better flint supply seems problematic. Another characteristic of Ormesson Discoid assemblage is, for the moment, the scarcity of retouched implements, in particular of notches and denticulates which frequently characterize the techno-complex in South-western France. Are such characteristics representative of a state of progress in the excavations? Are they relevant of local techno-economic tactics, or subtle cultural specificities?

In addition to ongoing excavation progress at Ormesson, a complementary way to solve these questions will be to enlarge the scope of the analysis to the whole Paris Basin. In that space, Discoidal assemblages have been now studied from very contrasting geographical and lithological contexts. For instance, Arcy-sur-Cure cave sites, on one side, Beauvais and Mennecy open-air sites on the other side, are respectively located at the very margin and near the center of the limestone dominated basin. As a consequence we observe great variations of flint availability from these different contexts. The preliminary comparison of the datas available confirms the existence of similar knapping methods and goals during a limited period, broadly centered on the MIS 3. But it also suggests some intrinsic adaptability of the Discoid typo-technological system to raw material nature and availability. When replaced in that perspective, the different characteristics of stone tool production currently recognized at Ormesson don't appear, so far, to underline any cultural peculiarity on that site and fit with a coherent vision of the Discoid techno-complex also in Northern part of France. In return, the singular preservation of Ochre at Ormesson, offers a punctual opportunity to integrate what we increasingly know about these knapping habits with more obscure but anyway complementary aspects of a cultural system. 


\title{
NeANdertal ocCUPATION DURING MIS 5e at CAOURS (NORTHERn FranCE): A MULTIDISCIPLINARY STUDY
}

\author{
Nicole Limondin-Lozouet ${ }^{1}$, Jean-Luc Locht ${ }^{1,2}$, Pierre Antoine ${ }^{1}$, Patrick Auguste ${ }^{3}$, Julie Dabkowski ${ }^{1}$ \& \\ Bassam Ghaleb ${ }^{4}$
}

\author{
${ }^{1}$ UMR 8591 CNRS, Université Paris I, Laboratoire de Géographie Physique, "Environnements quaternaires et géoarchéologie", \\ Meudon (France); limondin $@$ bellevue.cnrs-bellevue.fr \\ ${ }^{2}$ INRAP Nord-Picardie, Amiens (France) \\ ${ }^{3}$ UMR 8217 CNRS, Université Lille 1, Villeneuve d'Ascq (France) \\ ${ }^{4}$ GEOTOP, Université du Québec à Montréal, Montréal (Canada)
}

Recent investigations in the River Somme basin have allowed the discovery of an exceptionally well preserved calcareous tufa formation overlying an alluvial sequence at Caours (Scardon valley). The base of this alluvial formation, composed by periglacial gravels, lies at $+6 \mathrm{~m}$ above the modern valley bedrock and belongs to the lowest terrace within the Somme terrace system. The calcareous tufa is separated from the underlying periglacial alluvial gravels by fluvial calcareous silts overlain by a marshy soil and a thin peat layer. The whole sequence, has provided abundant malacological faunas allowing palaeoenvironmental and climatic reconstructions. The initial overbank fluvial silts yield assemblages of open ground including coldloving species allowing the recognition of Lateglacial climatic conditions. In the upper part of the silts, land snails communities reveal a dramatic change to open forest environments indicating early Interglacial climate. Subsequent full temperate faunas in the tufa contain increasing amounts of forest snails, these are up to $70 \%$ in the last organic layer and correspond to the climatic optimum of the Interglacial. Tufa geochemistry $\left(\delta^{18} \mathrm{O}\right.$ and $\left.\delta^{13} \mathrm{C}\right)$ provides results consistent with this interpretation. At least four distinct archaeological levels have been evidenced at the base of the sequence: one in the upper part of the calcareous silts, one at the surface of the peat layer and two within thin organic tufa horizons included in the base of the calcareous tufa deposit. They are characterized by flint industries associated with interglacial large mammal (Cervus elaphus, Dama dama, Bos primigenius, Stephanorhinus hemitoechus, Sus scrofa) and include thermophilous rodent remains (Apodemus sylvaticus). Taking into account its relative position within the Somme terraces system, the U/Th (TIMS) ages (average $123 \pm 3$ ky B.P.) and the results of the bioclimatic studies, the Caours sequence represents the first record of the Eemian interglacial in the Somme basin. Moreover the archaeological levels discovered at Caours are a unique example of Neandertal occupation during the Last Interglacial in Northern France in full forested environments.

\section{References}

Antoine P., Limondin-Lozouet N., Auguste P., Locht J.-L., Galheb B., Reyss J.-L., Escude É., Carbonel P., Mercier N., Bahain J.-J., FAlguÈres C. \& Voinchet P., 2006. Le tuf de Caours (Somme, Nord de la France): mise en évidence d'une séquence de tufs calcaires eemiens et d'un site paléolithique associé. Quaternaire, 17 (4): 281-320. 


\title{
The Middle Palaeolithic of northern France
}

\section{Jean-Luc Locht ${ }^{1,2}$, Émilie Goval ${ }^{1,3}$, David Hérisson ${ }^{3,4}$, Pierre Antoine $^{2}$ \& Sylvie Coutard ${ }^{1}$}

\author{
${ }^{1}$ INRAP Nord-Picardie, Amiens (France); jean-luc.locht@inrap.fr \\ ${ }^{2}$ UMR 8591 CNRS, Université Paris I, Laboratoire de Géographie Physique, "Environnements quaternaires et géoarchéologie", \\ Meudon (France) \\ ${ }^{3}$ UMR 7194 CNRS, Département de Préhistoire, IPH, Paris (France) \\ ${ }^{4}$ INRAP CSNE, Croix Moligneaux (France)
}

The Middle Palaeolithic begins around 300 ky ago, and ends around $40 \mathrm{ky}$. During more than $250 \mathrm{ky}$, the whole Europe was occupied by Neandertal populations, which were characterized by very weak density and demography. The aim of the communication is to focus on the identities of the different cultural groups peopling northern France and to try to discern if "cultural provinces" could have existed in this area. Of course, data are distorted by the few number of well-preserved and well-dated sites, especially for the Saalian period of the Middle Palaeolithic. Data are lacking for the Marine isotopic stage 8 (MIS), while a low number of very important sites are known for MIS 7 (Biache-Saint-Vaast, Therdonne...). Nevertheless, the precision of the chronostratigraphic frame makes possible a diachronic and synchronic analysis of occupations, based on a coherent set of data.

The understanding of peopling identities and modalities is easier for the Weichselian period, where different cultural traditions seem to be identified during the Eemian, the Early Weichselian, the Lower and Middle Pleniglacials of the Weichselian. These distinctions are based on mixed technological and typological features (precise characterization of the lithic production and association of the different patterns [handaxes manufacture, discoidal debitage, Levallois or laminar productions, precise characterization of the goals of the productions,....]), because retouched tools are not numerous enough for precise attribution to one or the other Bordes' typological facies.
Human occupation in northern France is discontinuous, and influenced by several interactive factors as climatic and environmental changes, raw materials availability, large fauna density... This overview shows that Middle Palaeolithic is not a long uniform period, but a dynamic one undoubtedly characterized by numerous phases of emergence, colonisation and disappearance. 


\title{
Connecting Midde Palaeolithic Karstic AND lessic Sites: WHere do We STAND?
}

\section{Stéphane Pirson ${ }^{1}$, Kévin Di Modica ${ }^{2} \&$ Paul Spagna $^{3}$}

\author{
${ }^{1}$ Direction of Archaeology, Public Service of Wallonia, Namur (Belgium); stephane.pirson@spw.wallonie.be \\ ${ }^{2}$ Scladina Cave Archaeological Centre, Andenne (Belgium) \\ ${ }^{3}$ Department of Palaeontology, Royal Belgian Institute of Natural Sciences, Brussels (Belgium)
}

Belgium lies at the border of two worlds: the great lœssic plain in the north, and the Ardenne-Eifel Palaeozoïc massif in the south, including numerous caves. Dozens of Middle Palaeolithic sites have been found in both lœssic and karstic environments. This area therefore appears as an interesting spot to compare the assemblages from open air and caves. Since the $19^{\text {th }}$ Century, researchers have tried to make such comparisons, sometimes explaining the differences through distinct cultural behaviour (Dupont, 1873). However, the major problem is the poorly known age of these assemblages, mainly found during ancient excavations.

This paper will try to provide an up-to-date overview of the problematic, taking into account new excavations as well as recent advances in several field of research:

1. A better chronostratigraphic framework for loess sequences (Haesaerts et al., 2011), leading to refine the chronostratigraphic position of Middle Palaeolithic material (Pirson \& Di Modica, 2011).
2. A better understanding of sedimentogenesis in cave entrance environments, notably through experiments in active periglacial environment (Bertran et al., 2009) and recent developments in studies of slope processes (Bertran, 2004).

3. Recent studies of some cave sequences that demonstrated the possibility of correlating cave and lœss sequences in Belgium, thanks to several elements such as heavy mineralogy, pedostratigraphic markers or tephras (Pirson, 2011).

\section{References}

Bertran P. (dir.), 2004. Dépôts de pente continentaux. Dynamique et faciès. Quaternaire. Hors-série n¹, Paris, 259 p.

Bertran P., Beauval C., Boulogne S., Brenet M., Chrzavzez J., Claud E., Costamagno S., Laroulandie V., Lenoble A., Malaurent P., Masson B., Mallye J.-B., Sin P., Thiébaut C. \& Vallin L., 2009. Dynamique sédimentaire et taphonomie des abris-sous-roche et des porches de grotte en milieu périglaciaire. Le programme Gavarnie. Les Nouvelles de l'archéologie, 118: 11-16.

DuPONT E., 1873. Classement des âges de la pierre en Belgique. Congrès international d'Anthropologie et d'Archéologie préhistorique, 6ème session, Bruxelles, 1872: 459-479.

PIRSON S., 2011. Contextes paléoenvironnemental et chronostratigraphique du remplissage de la grotte Walou: apport de la géologie et comparaison avec les autres disciplines. In: Pirson S., Draily C. \& Toussaint M. (Eds), La grotte Walou à Trooz (Belgique). Fouilles de 1996 à 2004. Volume 1. Les sciences de la terre (Etudes et Documents, Archéologie 20): 170-201.

Pirson S. \& Di Modica K., 2011. Position chronostratigraphique des productions lithiques du Paléolithique ancien en Belgique: un état de la question.. In: Toussaint M., Di Modica K. \& Pirson S. (Dir.), Le Paléolithique moyen en Belgique. Mélanges Marguerite Ulrix-Closset (ERAUL 128, Bulletin des Chercheurs de la Wallonie Hors-série No 4): 105-148.

HAESAERTS P., PIRSON S. \& MeIJS E., 2011. New proposal for the Quaternary lithostratigraphic units (Belgium). Aeolian sediments. National Commission for Stratigraphy, Subcommission Quaternary, http://ncs.drupalgardens.com/quaternary/lithostratigraphy: 1-7. 


\title{
Through a Neanderthal's eye: What does the Middle Palaeolithic Mean? THE STATE OF RESEARCH IN GERMANY.
}

\author{
Jürgen Richter ${ }^{1}$ \\ ${ }^{1}$ University of Cologne (Germany); j.richter@uni-koeln.de
}

Adaptational strategies and technological concepts of the Middle Palaeolithic emerged around 300,000 years ago and persisted until 40,000 years ago. The Middle Palaeolithic covered the whole time span of the Neandertal human lineage and reached as far back as the time of late Homo heidelbergensis. During the long time of its existence, the Middle Palaeolithic had to overcome major climatic and environmental challenges (f.e. glacial maxima around 150 and 70-60 ky B.P., but also phases of forest yield with shrinking ungulate biomass 240190 and 130-70 ky B.P.) connected with dramatic demographic change among Neandertal populations.

Seen from the Neandertal demographic perspective, immigration, contraction, dispersal, fragmentation, emigration, regional extinction of populations and subsequent resettlement must have occurred several times. On the continental scale we should thus expect a colourful patchwork of different technologies and toolkits, emerging and vanishing at different places and times - and this is exactly what we see: Technological and typological phenomena appear and disappear such as their authors would play with a bookshelf full of cookery books, taking out a specific recipy book from time to time just to put it back after the preparation of the meal. Typological concepts such as asymmetric bifacial tools (Keilmesser) occur at several times and at different places during the Middle Palaeolithic. And technological recipies such as the recurrent centripetal Levallois method occcur several times at different places during the Middle Palaeolithic.

This is why large scale distribution maps and large scale chronological models of simplified types and technotypes - as frequently set up in the last century - have resulted in nothing else than repeating the patchwork pattern which is to be expected a priori based on the mentioned demographic reasons.
Consequently, it is absolutely not surprising that the majority of all predictions about the chronological value of simplified types and technotypes have regularly turned out to be erroneous. Generally, dating has to rely nowadays on radiometry, palaeomagnetism, stratigraphy, palynology, palaontology and other scientific disciplines, but not on simplified types and technotypes. Research of the last two decades has considerably changed our notion of the cultural units connected with the late Middle Palaeolithic of Europe. The revision of lithic assemblages from Middle Palaeolithic sites in Germany resulted in a new understanding of the relationship between techno-typological entities of artefact assemblages, On the one hand, and the utilization of prehistoric natural landscape, on the other hand. The aim is to deliver a complete reconstruction of an annual cycle of activities and mobility within a territory in order to understand the composition of assemblages, the structures of sites and their location within the landscape before cultural affiliations can be traced. The present paper strongly advocates for medium-scale approaches aiming at a better understanding of Neandertal cultural behaviour within a given chronological and regional context. Allover Europe I see a growing number of comparable research programmes on the road. This is a stony road and I would kindly invite you to accompany us! 


\title{
EVALUATING FUNCTIONAL DATA ON TOOL USE, HAFTING AND SITE FUNCTION IN THE EUROPEAN Middle Palaeolithic
}

\author{
Veerle Rots ${ }^{1}$ \\ ${ }^{1}$ Department of Prehistory, University of Liège, Liège (Belgium); Veerle.Rots@ulg.ac.be \\ Functional data are still quite fragmentary with \\ regard to the Middle Palaeolithic in Europe, but \\ recent advances can be noted. On a methodological \\ level, microwear analyses have been \\ complemented with residue analyses and this has \\ provided new insights on Neandertal subsistence \\ even though some caution is necessary. Analyses \\ have also demonstrated that stone tool hafting was \\ results support a model in which the choice to haft \\ a tool was largely determined by task frequency \\ and site function. No gradual increase in the \\ frequency of hafting was yet observed within the \\ European Middle Palaeolithic. Aside from a \\ critical review of available functional data, results \\ on tool use, hafting and site function on a number \\ of Middle Palaeolithic sites will be presented.
} part of the technological organisation and that its application was not uncommon at all. Current 


\section{NEW FOSSILS AT THE “TROISIÈME CAVERNE" OF GOYET (BELGIUM) AND THE MORTUARY PRACTICES OF LATE NEANDERTALS}

\section{Hélène Rougier ${ }^{1}$, Isabelle Crevecoeur ${ }^{2}$, Cédric Beauval ${ }^{3}$, Damien Flas ${ }^{4}$, Hervé Bocherens ${ }^{5}$, Christoph Wißing ${ }^{5}$, Mietje Germonpré ${ }^{6}$, Patrick Semal ${ }^{6} \&$ Johannes van der Plicht ${ }^{7}$}

\footnotetext{
${ }^{1}$ Department of Anthropology, California State University, Northridge (USA); helene.rougier@esun.edu

${ }^{2}$ UMR 5199 CNRS, Université Bordeaux 1, Laboratoire PACEA, Talence (France)

${ }^{3}$ Archéosphère (France)

${ }^{4}$ FNRS, Department of Prehistory, University of Liège, Liège (Belgium)

${ }^{5}$ Fachbereich Geowissenschaften - Biogeologie, Universität Tübingen (Germany)

${ }^{6}$ Operational Direction "Earth and History of Life", Royal Belgian Institute of Natural Sciences (Belgium)

${ }^{7}$ Centre for Isotope Research, Groningen University (The Netherlands)
}

Neandertal discoveries in Belgium have played an important role in the history of European palaeoanthropology. Late Neandertal fossils within the collections of the "Troisième Caverne" of Goyet (Gesves, Belgium) have recently been identified by our multidisciplinary team. These fossils provide an opportunity to assess the variability of Late Neandertal mortuary practices.

The "Troisième Caverne" of Goyet, excavated at the end of the $19^{\text {th }}$ and early $20^{\text {th }}$ century, yielded a rich archeological sequence ranging from the Middle and Upper Palaeolithic to historical times. In 2008 we began documenting the Palaeolithic occupations of the "Troisième Caverne" by reassessing the collections from the site, which heretofore had only been partially studied. The updated inventory of human remains was accomplished by conducting a detailed sorting of the palaeontological collections in order to identify human remains that may have been overlooked thus far. As a result, the collections from the
"Troisième Caverne" now include nearly 200 human bones/bone fragments and isolated teeth that correspond to various materials from different periods.

The morphometric study of the human specimens from Goyet, completed by direct radiocarbon dating and stable isotope analysis, reveals that they represent two main samples: a large and fragmentary series of Late Neandertal remains (Rougier et al. 2012) and a set of modern human specimens from the Upper Palaeolithic (Rougier et al. 2013). The Neandertal remains include elements from the cranial and infra-cranial skeleton which represent at least 3 different individuals. The Neandertal specimens of Goyet also present numerous anthropogenic traces that are similar to those found on the fauna remains from the site. We have interpreted them as evidence of cannibalism and will discuss our observations in terms of mortuary behaviour variability among Late Neandertals.

\section{Acknowledgements}

This research was funded by the Wenner-Gren Foundation (Gr. 7837), the College of Social and Behavioural Sciences of CSUN, and the CSUN Probationary Faculty Support Program.

\section{References}

Rougier H., Crevecoeur I., Beauval C., Bocherens H., Flas D., Germonpré M., Semal P. \& van der Plicht J., 2012. New data from an old site: Neandertals at Goyet (Belgium) and their mortuary behaviour. American Journal of Physical Anthropology, 147: 252-253.

Rougier H., Crevecoeur I., Beauval C., Flas D., Bocherens H., Wibing C., Germonpré M., Semal P. \& van Der Plicht J., 2013. The first Upper Palaeolithic human remains from Belgium: Aurignacian, Gravettian and Magdalenian fossils at the "Troisième Caverne" of Goyet. PaleoAnthropology, 2013: A 33. 


\title{
REGIONAL BEHAVIOUR AMONG LATE NEANDERTHAL GROUPS IN WESTERN EUROPE:

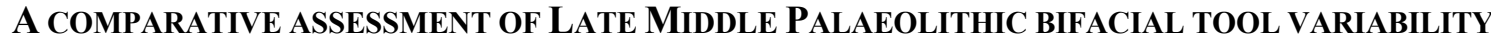

\author{
Karen Ruebens ${ }^{1}$ \\ ${ }^{1}$ Department of Human Evolution, Max Planck Institute for Evolutionary Anthropology, Leipzig (Germany); \\ Karen.ruebens@eva.mpg.de
}

A growing number of studies have emerged that highlight spatio-temporal differences among Neandertal stone tool assemblages (Soressi, 2002; Jöris, 2004; Ruebens and Di Modica, 2011). This directly contradicts previous views of the Middle Palaeolithic as a period of uniformity and stasis. For example, during the later phase of the Middle Palaeolithic (MIS 5d-3; ca.115,000-35,000 B.P.) bifacial technologies re-emerge, after a near absence in the Western European Early Middle Palaeolithic (Iovita and McPherron, 2011). These bifacial tools occur across Europe, are associated with classic Neandertals and contain a variety of types and forms. Moreover, several types seem associated with a restricted geographic occurrence. Therefore, Late Middle Palaeolithic bifacial tools provide a unique record for a data-driven, widerscale assessment of Neandertal behavioural variability, population dynamics and regionality.

Previous studies of Late Middle Palaeolithic bifacial tools were hampered by a convoluted plethora of competing terms, types and regional entities. Is often obscured the assessment of genuine similarities and led to the current disjointed view on this bifacial phenomenon. This paper presents the first, large-scale comparative study of this tool type, bridging typo-technological and spatio-temporal data from across Western Europe (Britain, Belgium, the Netherlands, France and Germany; Ruebens, 2013). A threefold methodological framework was applied:

1. A new classificatory scheme for Late Middle Palaeolithic bifacial tools was developed, defining five bifacial tool concepts based on least common typo-technological denominators, overcoming past epistemological issues and facilitating interassemblage comparisons.

2. A total of 1,303 bifacial tools from 14 case study assemblages formed part of a detailed attribute analysis, recording information on artefact condition, metrics and typo-technological features.

3. The bifacial tools from an additional 67 comparison sites were also reclassified according to the new scheme, culminating in comparative bifacial tool data from 81 assemblages.

Results indicate a high level of variation between individual bifacial tools and assemblages. Each bifacial tool concept is correlated with various production methods, resulting in large amounts of morphological variation. Despite such variation, a distinct threefold typo-technological pattern was identified that correlates to three macro-regional entities; the Mousterian of Acheulean Tradition (MTA) in the southwest dominated by handaxes; the Keilmessergruppen (KMG) in the northeast typified by backed and leaf-shaped bifacial tools; and, finally a new unit, the Mousterian with Bifacial Tools (MBT), geographically situated between these two major entities, and characterised by a wider variety of bifacial tools. Differing local conditions, such as raw material or function, are not sufficient to explain this observed macro-regional tripartite. Instead, it is argued that the MTA and KMG can be viewed as two distinct cultural traditions, where the production of a specific bifacial tool concept was passed on over generations. Conversely, the MBT is viewed as a border zone where highly mobile groups of Neandertals from both the east (KMG) and west (MTA) interacted.

Principally, this study presents an archaeological contribution to behavioural concepts such as regionality, culture, social transmission and population dynamics. It illustrates the interpretive potential of large-scale lithic studies, and more specifically the presence of regionalised cultural behaviour among late Neandertal groups in Western Europe. 


\section{Acknowledgements}

This study was funded through a doctoral grant from the Arts and Humanities Research Council (AHRC) and conducted at the University of Southampton (supervisor: Dr John McNabb, advisor: Dr William Davies).

\section{References}

Iovita R. \& McPherron S.P., 2011. The Handaxe reloaded: a morphometric assessment of Acheulean and Middle Palaeolithic handaxes. Journal of Human Evolution, 61 (1): 61-74.

JÖRIS O., 2004. Zur chronostratigraphischen Stellung der spätmittelpaläolithischen Keilmessergruppen. Der Versuch einer kulturgeographischen Abgrenzung einer mittelpaläolithischen Formengruppe in ihrem europäischer Kontext. Bericht der Römisch -Germanischen Kommission, 84: 49-153.

RuEBENS K. \& Di Modica K., 2011. Les productions bifaciales du Paléolithique moyen sur le territoire belge: presentation d'industries entre deux mondes. In: Toussaint M., Di Modica K. \& Pirson S. (Dir.), Le Paléolithique moyen en Belgique. Mélanges Marguerite Ulrix-Closset (ERAUL 128, Bulletin des Chercheurs de la Wallonie Hors-série No 4): 239-260.

Ruebens K., 2013. Regional behaviour among late Neanderthal groups in Western Europe: a comparative study of Late Middle Palaeolithic bifacial tools. Journal of Human Evolution, 65 (4): 341-362.

SORESSI M., 2002. Le Moustérien de tradition acheuléenne du sud-ouest de la France. Discussion sur la signification du faciès à partir de l'étude comparée de quatre sites: Pech-de-l'Azé I, Le Moustier, La Rochette et la Grotte XVI. Ph.D. Dissertation, Université de Bordeaux I, $330 \mathrm{p}$. 


\title{
LESS OF THE LOWER RHINELAND
}

\author{
Wolfgang Schirmer ${ }^{1}$
}

${ }^{1}$ Dept. of Geology, Heinrich Heine University, Düsseldorf (Germany); schirmer@ $@$ uni-duesseldorf.de

In the area of the Lower Middle Rhine and the Lower Rhine a stack of up to $55 \mathrm{~m}$ thick lœss deposits shows a distinct subdivision by solcomplexes and by sedimentological discordances (Fig. 1).

\section{Lithological subdivision}

Lithologically the lœss stack is subdivided by two formations. The Upper Lœss Formation encompasses five subformations ascribed to the Late Pleistocene (MIS 5-2), from young to old: the Brabant, Hesbaye, Ahrgau, Keldach and Rheingau Subformations (SF). The Lower Lœss Formation encompasses - as far as we know at present seven subformations ascribed to the Middle Pleistocene (MIS 6 to at least 11), from young to old: the Wetterau, Gillgau, Limburg, Mülgau, Kützgau, Geldern and Jülich Subformations (SF).

While the Brabant SF has been preserved as blanket of the Rhine-Maas plateau up to $6 \mathrm{~m}$ thick, the older lœss deposits are preserved only locally in tectonical or morphological depressions or in lee slope positions.

\section{Subdivision by solcomplexes}

The lœss stack is subdivided by four solcomplexes that each represent an interglacial complex. The solcomplexes comprise each 2-5 Bt horizons, humus zones and sometimes gelic gleysols (Nassböden) each separated by thin lœss layers. In case of the Garzweiler Solcomplex (MIS 5) it can be demonstrated that this solcomplex embraces at least one interglacial (Eemian) represented by the Erbach Bt horizon. It is followed by Bt horizons representing very mature interstadials (Brørup and Odderade). In addition, each Bt horizon is followed by a separate humus zone which represents certain warming phases (Schirmer, 2000a, b).

From this follows: An interglacial solcomplex is a cluster of preferably terrestric and minor semiterrestric soils that comprises at least one interglacial period, sometimes two or more, and a range of interstadial periods. These warm periods are separated by thin loess layers representing short cold periods with lœss deposition, called breviglacials sensu Schirmer 1999a. As a whole, the solcomplex with its soils and breviglacial losses forms a long period of quiescence of the landscape. During the long period of duration of a solcomplex there occur neither thick essential accumulation nor major erosion which transform the landscape basically (Schirmer, 1999a).

The Garzweiler Solcomplex is ascribed to MIS 5. The Erft Solcomplex should be assigned to MIS 7. The Rur and Niers Solcomplexes follow beneath. They may represent MIS 9 and 11 or they are older owing to possible erosional discordances.

The Ahr Interstadial Solcomplex representing the Middle Pleniglacial of the last Glacial (MIS 3) embraces a characteristic sequence of $\mathrm{B}$ and $\mathrm{A}$ horizons, the Remagen Soils 1-5 and Sinzig Soils 1-3 (Schirmer, 1990, 1995, 2012). These eight calcic cambisols are each separated by thin solifluctional lœss layers. However, two of these lœss layers are somewhat thicker thus forming three groups of soil clusters, two Lower Remagen Soils, three Upper Remagen Soils and three Sinzig Soils. This interstadial solcomplex can be considered being an initial climate stage of an interglacial solcomplex (Schirmer, 2002).

\section{Subdivision by sedimentological discordances (event stratigraphy, discordance stratigraphy)}

Normally a lœss stack encompasses an abundance of sedimentary pauses, those are times without deposition or minimal deposition, or times of soil formation or even times with erosional discordances. In any case lœss sedimentation is shorter than the sedimentary breaks in between. Most of the erosional discordances can be followed only over short distances and are of minor relevance. Moreover, each of the fossil soils ends with a sedimentary discordance visible by a certain truncation of the soil. However, there are major discordances that deeply and extensively truncate and revolutionize the lœss landscape (Schirmer, 2003a, 2003b, 2003c). They can be identified by tracing them over longer distances in large 
outcrops or over several outcrops. Such are from old to young: the Mülgau Discordance in the lower Mülgau SF, the Wetterau Discordance in the lower Wetterau SF, the Keldach Discordance in the lower Keldach SF, the Hesbaye Discordance in the lower Hesbaye SF and the Eben Discordance in the upper Hesbaye SF. The Wetterau Discordance was observed being the strongest and deepest downencroaching, sometimes eroding down to the Jülich $\mathrm{SF}$. The Eben Discordance is smooth in plateau position, but in slope position it can also take off all the older formations as seen in the open cast mine Frimmersdorf West (Schirmer, 2003d). Discordances positioned close to the base of a lœss subformation, following a quiet soil formation period, may be the event of a frequent freeze-thaw action. Major discordances (e.g. Wetterau or Eben Discordance) may be caused by permafrost decay (Schirmer, 2000, 2003b, 2003d).

Thus, major sedimentological discordances are climate-morphogenetical events that provide essential elements for subdivision of unconformity-bounded units and understanding the landscape evolution.

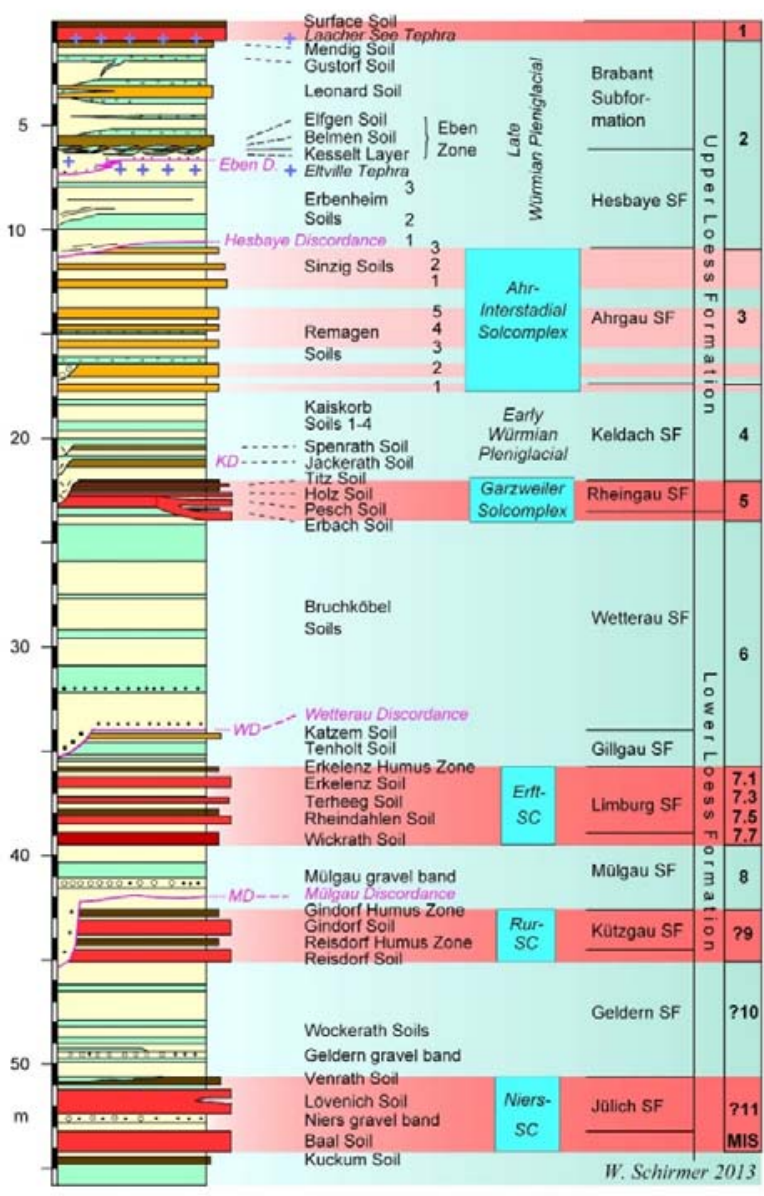

Figure 1

Rhine loess record. $\mathrm{KD}=$ Keldach Discordance . Modified after SCHIRMER (2010).

\section{References}

SCHIRMER W., 1990. Schwalbenberg südlich Remagen. In: Schirmer W. (Ed.), Rheingeschichte zwischen Mosel und Maas (deuquaFührer, 1): 105-108.

Schirmer W., 1995 (with contrib. by H. Berendsen, R. Bersezio, A. Bini, F. Bittmann, G. Crosta, W. De Gans, T. DE Groot, D. Ellwanger, H. Graf, A. Ikinger, O. Keller, U. Schirmer, M. W. van den Berg, G. Waldmann, L. Wick). Rhein Traverse. In: Schirmer W. (Ed.), Quaternary field trips in Central Europe, 1: 475-558.

SCHIRMER W., 1999a. Kaltzeiten und Warmzeiten im Löß. In: Becker-Haumann R. \& Frechen M. (Eds), Terrestrische Quartärgeologie: 81-100.

SCHIRMER W., 2000a. Rhein lœss, ice cores and deep-sea cores during MIS 2-5. Zeitschrift der Deutschen Geologischen Gesellschaft, 151: 309-332.

SCHIRMER W., 2000b. Eine Klimakurve des Oberpleistozäns aus dem rheinischen Löss. Eiszeitalter und Gegenwart, 50: 25-49 (Hannover).

SCHIRMER W., 2002. Frühes Würm/Weichsel im Rahmen der Glazial-Interglazial-Gliederung. Terra nostra, 2002 (6): $314-321$ (Berlin). SCHIRMER W., 2003a. Stadien der Rheingeschichte. In: Schirmer W. (Ed.), Landschaftsgeschichte im Europäischen Rheinland (GeoArchaeoRhein, 4): 21-80.

SCHIRMER W., 2003b. Event-Stratigraphie vom Rheingletscher zum Rhein. In: Schirmer W. (Ed.), Landschaftsgeschichte im Europäischen Rheinland (GeoArchaeoRhein, 4): 125-126.

SCHIRMER W., 2003c. Zur reliktischen Erhaltung älterer Lösse. In: Schirmer W. (Ed.), Landschaftsgeschichte im Europäischen Rheinland (GeoArchaeoRhein, 4): 153-154.

SCHIRMER W., 2003d. Die Eben-Zone im Oberwürmlöss zwischen Maas und Rhein. In: Schirmer W. (Ed.), Landschaftsgeschichte im Europäischen Rheinland (GeoArchaeoRhein, 4): 351-416.

SCHIRMER W., 2010. Interglacial complex and solcomplex. Central European Journal of Geosciences, 2 (1): 32-40.

SCHIRMER W., 2012. Rhine lœss at Schwalbenberg II - MIS 4 and 3. Eiszeitalter und Gegenwart, 61 (1): 32-47. 


\title{
THE MOURNING DAWN: NEANDERTHAL FUNERARY PRACTICES AND COMPLEX RESPONSES TO DEATH
}

\author{
Sarah Schwarz ${ }^{1}$ \\ ${ }^{1}$ Centre of the Archaeology for Human Origins (CAHO), Department of Archaeology, University of Southampton (UK); \\ S.M.Schwarz@,soton.ac.uk
}

This paper addresses variability in a range of potential Neandertal funerary practices from sites across Europe and Asia. A database of all known Neandertal remains to date has been created using a range of published sources, and each individual examined for characteristics of a range of funerary practices to identify which, if any, were being used by Neandertals. Although Neandertal burials have been questioned in the past, the number of characteristics identifying the sites as deliberate funerary acts, the number found in each site strongly indicates that funerary practices were regularly employed by Neandertals.

Initial analysis of the data indicates that evidence of corpse processing techniques, such as defleshing and disarticulation, can be seen in the archaeological record even with Early Neandertals, and later the introduction of burial by Classic Neandertals. However, evidence of a variety of funerary practices is evident across the Neandertal world.

Funerary practices do not express any statistically significant variability by geographical location or biological factors, such as gender or age at death. In other words, regardless of whether you are a baby boy or an old woman, the living Neandertal groups will treat every deceased individual the same. Can we therefore assume an 'ad hoc' approach is being used by Neandertals? What other factors could determine how a deceased Neandertal was treated by the living group? And how do funerary sites fit into the Neandertal landscape? 


\title{
THE ADULT NEANDERTALS FROM SPY AND THE VARIABILITY OF LATE NEANDERTALS
}

\author{
Patrick Semal $^{1}$, Isabelle Crevecoeur ${ }^{2} \&$ Hélène Rougier ${ }^{3}$
}

\author{
${ }^{1}$ Operational Direction "Earth and History of Life", Royal Belgian Institute of Natural Sciences (Belgium); \\ patrick.semal@sciencesnaturelles.be \\ 2 UMR 5199 CNRS, Université Bordeaux 1, Laboratoire PACEA, Talence (France) \\ ${ }^{3}$ Department of Anthropology, California State University Northridge (USA)
}

The adult Neandertals from Spy represent one of the major palaeoanthropological discoveries of the second part of the 19th century. For the first time, the association of Neandertal remains with Ice Age fauna and Middle Palaeolithic artefacts was observed in situ. This important skeletal assemblage was presented in the first monographic publication dedicated to Neandertal fossils (Fraipont \& Lohest, 1887) but it had not been exhaustively studied until the monograph published by our team (Rougier \& Semal, 2013, 2014 [in press]).

The recent re-assessment of the Spy human collection allowed us to revise the individual attributions of the Neandertal remains and to identify new osseous elements belonging to the two adult Neandertals Spy I and Spy II. Direct radiocarbon dating suggests the contemporaneity of the two adult Neandertals and places them around 36,000 B.P. (Semal et al., 2009). Other analyses such as the identification of plant microfossils trapped in dental calculus (Henry et al., 2011) and stable isotopes (Bocherens et al., 2013) suggest a similar diet for the two individuals supporting their contemporaneity and a similar way of life. Based on these new results, we propose a re-evaluation of the biological characteristics of Spy I and II and to compare them with other Late Neandertals.

The infra-cranial remains of Spy I and Spy II show clear Neandertal affinities while their cranial and dental remains are situated differently in the Neandertal variation. Some of the dental features of Spy II display an "intermediate" position between Neandertals and anatomically modern humans (AMH).

These results suggest a high level of interindividual Neandertal variation within a single site. The overlapping between the variablity of the Late Neandertals and of the first AMH may have been underestimated even for criteria used for taxonomic diagnosis such as some dental traits.

\section{Acknowledgements}

This research was conducted in the context of a "Research Action" funded by the Belgian Science Policy (BELSPO 2004-2007, MO/36/0112: "Multidisciplinary study of the collections from Spy Cave: new technical and scientific approaches"). The complete digitisation of the Spy Neandertal skeletal elements by Computed Tomography was performed in the context of the TNT project (6th framework Program, strep 2004-2006). The Spy dating program was funded by the FRS-FNRS.

\section{References}

Bocherens H., Germonpré M., Toussaint M. \& Semal P., 2013. Stable isotopes. In: Rougier H. \& Semal P. (Eds), Spy Cave. 125 years of multidisciplinary research at the Betche aux Rotches (Jemeppe-sur-Sambre, Province of Namur, Belgium). Volume 1 (Anthropologica et Praehistorica 123): 357-370.

FraiPONT J. \& LOHEST M., 1887. La race humaine de Néanderthal ou de Canstadt en Belgique. Recherches ethnographiques sur des ossements humains découverts dans les dépôts quaternaires d'une grotte à Spy et détermination de leur âge géologique. Archives de Biologie, 7: 587-757.

HeNRY A. G., BROOKS A. S. \& PIPERNo D. R., 2011. Microfossils in calculus demonstrate consumption of plants and cooked foods in Neanderthal diets (Shanidar III, Iraq; Spy I and II, Belgium). Proceedings of the National Academy of Sciences USA, 108(2): 486491.

Rougier H. \& SEMAL P. (Eds), 2013. Spy Cave. 125 years of multidisciplinary research at the Betche aux Rotches (Jemeppe-surSambre, Province of Namur, Belgium). Volume 1 (Anthropologica et Praehistorica 123), 386 p.

Rougier H. \& Semal P.. (Eds), 2014 [in press]. Spy Cave. 125 years of multidisciplinary research at the Betche aux Rotches (Jemeppesur-Sambre, Province of Namur, Belgium). Volume 2 (Anthropologica et Praehistorica 124).

Semal P., Rougier H., Crevecoeur I., Jungels C., Flas D., Hauzeur A., Maureille B., Germonpré M., Bocherens H., Pirson S., Cammaert L., De Clerck N., Hambucken A., Higham T., Toussaint M. \& van Der Plicht J., 2009. New Data on the Late Neandertals: Direct Dating of the Belgian Spy Fossils. American Journal of Physical Anthropology, 138: 421-428. 


\section{THE LAST 500,000 YEARS OF HUMAN EVOLUTION IN EURASIA: FOSSIL AND GENETIC PERSPECTIVES}

\section{Chris Stringer ${ }^{1}$}

${ }^{1}$ The Natural History Museum, London (UK); c.stringer@nhm.ac.uk

Many different models and scenarios have been proposed for the later stages of human evolution in Eurasia. Was there continuity of a Neandertal lineage stretching back to the Sima de los Huesos hominins at about 600,000 years, thus suggesting Homo heidelbergensis was just the earliest part of that lineage? Or was heidelbergensis a widespread species that gave rise to both the Neandertals in Western Eurasia and the lineage of modern humans in Africa, with a probable origin for those descendant lineages within the last 450,000 years? In addition, the discovery of a distinct human lineage represented by genomic data from Denisova Cave in Siberia has produced further complexity in the Eurasian story. Is this a new kind of human, distinct from but related to the Neandertals, and might this lineage be represented in Asian fossils such as Dali, Jinniushan, Maba and Narmada?

Further genetic data promise to both clarify and complicate our scenarios of Eurasian human evolution. It seems increasingly likely that the Sima fossils are no older than 400,000 years, and represent a post-heidelbergensis and Neandertallike population. Yet genetic data suggest a relationship to the Denisovans. And the genomes of Neandertals and Denisovans show how small and inbred these populations were, despite their time depth, and actual or inferred geographical ranges.
Further work on Neandertal and Denisovan DNA transferred to recent human genomes through interbreeding reveals areas where having their DNA may have conferred advantages to modern humans, and larger areas where it has been selected out, suggesting that it was suboptimal and may have led to reduced fertility. Synthesising the burgeoning genetic data with the fossil record is a massive task, but this will certainly be invaluable in untangling the story of human evolution in Eurasia during the last 500,000 years. 


\title{
EARLY PREHISTORY UNDER THE SEA: InVestigating Midde Palaeolithic ARChAEOLOGY AND SUBMERGED LANDSCAPES IN THE SOUTHERN NORTH SEA
}

\author{
Louise Tizzard $^{1}$, Andrew R. Bicket ${ }^{2}$, Jonathan Benjamin ${ }^{3}$ \& Dimitri De Loecker ${ }^{4}$
}

\footnotetext{
${ }^{1}$ Wessex Archaeology, GeoServices, Salisbury (UK); 1.tizzard@wessexarch.co.uk

${ }^{2}$ Wessex Archaeology, Coastal \& Marine, Edinburgh (UK)

${ }^{3}$ Flinders University, Department of Archaeology, Adelaide (Australia)

${ }^{4}$ Faculty of Archaeology, Leiden University, Leiden (The Netherlands)
}

To date, over 120 flint artefacts have been recovered from within Area 240, a marine aggregate licence area situated $11 \mathrm{~km}$ off the coast of Norfolk, England, located on the inundated floodplain of the palaeo-Yare river system. The artefacts comprise a mixture of Acheulian and Levallois lithic technologies (Lower and Middle Palaeolithic tools), a proportion of which were recovered in pristine condition suggesting they are from preserved in situ archaeological horizons. Between 2007 and 2013 a major programme of fieldwork and analysis was undertaken producing numerous and diverse datasets - geophysical, geotechnical, palaeoenvironmental and archaeological - each subject to its own specialist techniques of collection and analysis. Combined, the data have led to a comprehensive reconstruction of the development and preservation of the landscapes of Area 240 and have allowed assessment of the quantity and extent of archaeological, palaeoenvironmental and palaeontological material within Area 240. The in situ Early Middle Palaeolithic lithics were recovered from Middle Saalian (MIS 8/7) sediments dated to around 250 to $200 \mathrm{ky}$ when sea levels were around $50 \mathrm{~m}$ lower than present day. They have survived multiple phases of glaciation and marine transgression negating generalised assumptions that pre-Weischelian submerged prehistory in UK waters has been significantly reworked or destroyed by these factors. The investigations confirm that clear relationships between recovered artefacts and submerged and buried landscapes exist and that, although complex, can be examined in detail using a variety of existing fieldwork and analytical methods. 


\title{
NEANDERTAL MOBILITY PATTERNS IN THE MEUSE VALLEY: INSIGHTS AND PERSPECTIVES THROUGH STRONTIUM ISOTOPE ANALYSIS ON DENTAL ENAMEL
}

\author{
Christine Verna $^{1}$, Michel Toussaint ${ }^{2}$, Jean-Jacques Hublin ${ }^{3}$ \& Michael P. Richards ${ }^{3,4}$
}

${ }^{1}$ CNRS - UPR 2147, Paris (France); christine.verna@evolhum.cnrs.fr

${ }^{2}$ Direction of Archaeology, Public Service of Wallonia, Namur (Belgium)

${ }^{3}$ Department of Human Evolution, Max Planck Institute for Evolutionary Anthropology, Leipzig (Germany)

${ }^{4}$ Department of Anthropology, University of British Columbia, Vancouver, British Columbia (Canada)

Territorial movements and strategies are key elements in the adaptation of hunter-gatherer groups to their environment, which can also influence the evolutionary history of a hominin lineage. Indeed, the rhythm, frequencies, extent of contacts and interactions between groups, driven by their landscape use and territorial size are important factors of population dynamics. Here, we show how strontium ( $\mathrm{Sr}$ ) isotope analyses can bring new insights into the territorial mobility of Neandertal groups who were occupying the Meuse valley in the Pleistocene. We first show how ${ }^{87} \mathrm{Sr}{ }^{86} \mathrm{Sr}$ ratio of the bioavailable $\mathrm{Sr}$ (the strontium entering the food web) varies according to the various geological backgrounds surrounding the Meuse river at the regional scale. For these background data, we collected and analysed plant and snails specimens from 20 locations across different geological bedrocks. We then present the results obtained on the dental enamel of Neandertal individuals from the site of Engis, Scladina and Walou, for which we used a laser-ablation unit coupled to the mass spectrometer (MC-ICP-MS). The ${ }^{87} \mathrm{Sr}{ }^{86} \mathrm{Sr}$ ratio obtained on the enamel is compared to the bio-available strontium ratio in the different geological areas at the regional scale, as well as to Pleistocene mammal teeth found in the same archaeological sites. The results show a very local signature at the time of growth of the Engis and Scladina deciduous molars, i.e. very early childhood. The permanent premolar from Walou, as well as 11 teeth belonging to a single individual from Scladina representing different periods of life, allow us to discuss possible changes in lifetime mobility. Our study underlines longer-term perspectives of the application of such methods to territorial mobility question, despite several pitfalls that we also woud like to underline and discuss in this paper. We finally highlight how $\mathrm{Sr}$ isotope data, combined with other lines of evidence such as lithic raw material sourcing, can help understanding Neandertal landscape use in the Meuse region. 


\title{
The Middle Palaeolithic OF THe Netherlands: CONTEXTS AND PROSPECTS
}

\author{
Alexander Verpoorte ${ }^{1}$, Marcel J.L.Th. Niekus ${ }^{2}$, Dimitri De Loecker ${ }^{1}$ \& Eelco Rensink ${ }^{3}$
}

\footnotetext{
${ }^{1}$ Faculty of Archaeology, Leiden University, Leiden (The Netherlands)

${ }^{2}$ Lopendediep 28, 9712 NW Groningen (The Netherlands)

${ }^{3}$ National Heritage Agency, Amersfoort (The Netherlands)
}

The occupational history of northern latitudes is an important record of the evolution of adaptability in the human lineage. Investigations focus on the hominin species that visited and lived in northern regions, the chronology of occupation, the palaeogeographies, climates and ecologies, and the activities of hominins in these landscapes. We will review the Middle Palaeolithic record of the Netherlands in this context.

Four main regional settings are distinguished (from south to north):

1. The loss region, part of the North European loss belt: The middle Palaeolithic of this region is best known from the numerous, well-preserved find scatters excavated at Maastricht-Belvedere. Evaluation of the Saalian evidence for fire use, ochre, raw materials and transports suggests that the use of the Meuse river valley was not as shortterm and episodic as previously thought. Finds on the higher plateaus of the lœss region also indicate other archaeological patterning than found at Maastricht-Belvedere in the Meuse valley itself.

2. The Southern Netherlands, north of the loss: The record of the southern Netherlands consists mainly of a thin distribution of surface finds (patinated flakes, cores and bifaces). The Roer Valley Graben, a subsiding basin between two active faultlines (Peelrand and Feldbiss) is of potential interest for the preservation of Middle Palaeolithic remains in fine-grained, wet-eolian sediments. This is indicated by two localities: Esbeek and Den Bosch. Esbeek is a surface site with a concentration of small bifacial elements. In
Den Bosch, a small collection of finds was dredged from a depth of -7 to -9.50 meter NAP (Dutch mean sea level) with a discoid s.s. component as well as a well-preserved, cold fauna (e.g. woolly rhinoceros).

3. The Central Netherlands: The geology of the Central Netherlands is dominated by coarse fluvial sediments (gravels and sands) of the Rhine-Meusesystem. They are preserved in stacked terraces in the deep subsurface of the current river plain and in ice-pushed ridges of late Saalian age. The fluvial sequence covers the entire Late and Middle Pleistocene. Middle Palaeolithic finds are known from many localities as quarry and dredging finds. Best known is the pre-Saalian material described as the "Rhenen"-industry. The sediments are rich in well-preserved faunal remains such as remarkably slender reindeer from Woerden.

4. The Northern Netherlands, the post-Saalian landscape: The middle Palaeolithic record of the northern Netherlands after the retreat of the Saalian ice sheet consists mainly of surface finds. There are three larger concentrations. Two of these, Mander and Corversbosch, are located on the slope of moraine ridges. A third concentration of more than 500 artefacts including over 30 bifaces was recently discovered near Assen. Several artefacts were found in situ in sands (weathered residue of boulder clay) below the plowsoil.

On the basis of the current record, we will present an overview of the Middle Palaeolithic of the Netherlands in terms of chronological resolution, production systems, cultural affinities and find abundance. 


\section{INSIGHT INTO THE ECOLOGY OF NEANDERTALS IN NORTH-WEST EUROPE: STABLE ISOTOPES AND THEIR PALAEOBIOLOGICAL IMPLICATIONS}

\section{Christoph Wißing ${ }^{1}$, Hervé Bocherens ${ }^{1}$, Isabelle Crevecoeur ${ }^{2}$, Cédric Beauval ${ }^{3}$, Damien Flas ${ }^{4}$, Mietje Germonpré ${ }^{5}$, Patrick Semal ${ }^{5}$, Johannes van der Plicht ${ }^{6} \&$ Hélène Rougier $^{7}$}

\footnotetext{
${ }^{1}$ Fachbereich Geowissenschaften - Biogeologie, Universität Tübingen, Tübingen (Germany); christoph.wissing@uni-tuebingen.de

${ }^{2}$ UMR 5199 CNRS, Université Bordeaux 1, Laboratoire PACEA, Talence (France)

${ }^{3}$ Archéosphère (France)

${ }^{4}$ FNRS, Department of Prehistory, University of Liège, Liège (Belgium)

${ }^{5}$ Operational Direction "Earth and History of Life", Royal Belgian Institute for Natural Sciences, Brussels (Belgium)

${ }^{6}$ Centre for Isotope Research, Groningen University (The Netherlands)

${ }^{7}$ Department of Anthropology, California State University, Northridge (USA)
}

Little is known about the ecology, environmental conditions and cultural features of Neandertal communities in North-West Europe. The present study will provide a comprehensive view of the Late Pleistocene mammoth steppe ecosystems, which Neandertals belonged to, through the investigation of stable carbon and nitrogen isotopes $\left({ }^{13} \mathrm{C}\right.$ and $\left.{ }^{15} \mathrm{~N}\right)$ in collagen. Collagen is the predominant protein in bone and directly reflects the isotopic signature of the dietary components as well as environmental aspects of their habitat.

The analysis of Neandertal collagen coupled with that of contemporaneous herbivorous and carnivorous mammals allows to gain an insight into ecological aspects such as habitat characteristics, niche partitioning and trophic ecology, as well as into behavioural aspects such as prey preference of Neandertals in comparison with other large carnivorous mammals. We propose to evaluate the potential and limitations of the isotopic approach through a comparison of its results with those of other fields such as zooarchaeology and tooth wear analysis.

Our study will focus on North-West Europe during the Late Pleistocene till the last Neandertal fossils are documented in this region (ca. 36,000 years ago). We will pay particular attention to the Neandertal sites of Spy (Bocherens et al. 2012), Scladina (Bocherens et al. 1997, 2011) and Goyet in Belgium. Newly discovered Neandertals (Rougier et al. 2012) and coeval faunal remains from the "Troisième Caverne" of Goyet will be integrated in the context of previous research to provide a broad understanding of the Late Pleistocene mammoth steppe ecosystems that the Neandertals were a part of.

\section{References}

Bocherens H., Billiou D., Patou-Mathis M., Bonjean D., Otte M. \& Mariotti A., 1997. Paleobiological Implications of the Isotopic Signatures (13C, 15N) of Fossil Mammal Collagen in Scladina Cave (Sclayn, Belgium). Quaternary Research 48: 370380 .

Bocherens H., Drucker D. G., Bonjean D., Bridault A., Conard N. J., Cupillard C., Germonpré M., Höneisen M., Münzel S. C., Napierala H., Patou-Mathis M., Stephan E., Uerpmann H. P. \& Ziegler R., 2011. Isotopic evidence for dietary ecology of cave lion (Panthera spelaea) in North-Western Europe: Prey choice, competition and implications for extinction. Quaternary International, 245: 249-261.

Bocherens H., Germonpré M., Toussaint M. \& Semal P., 2012. Stable isotopes. In: Rougier H. \& Semal P. (Eds), Spy Cave. 125 years of multidisciplinary research at the Betche aux Rotches (Jemeppe-sur-Sambre, Province of Namur, Belgium). Volume 1 (Anthropologica et Praehistorica 123), 386 p.

Rougier H., Crevecoeur I., Beauval C., Bocherens H., Flas D., Germonpré M., Semal P. \& van der Plicht J., 2012. New data from an old site: Neandertals at Goyet (Belgium) and their mortuary behaviour. American Journal of Physical Anthropology, 147: $252-253$. 


\section{MIDDLE PALAEOLITHIC IN NORTH-WEST EUROPE}

MULTIDISCIPLINARY APPROACHES

\section{Poster Presentations}





\title{
WHEN NEANDERTALS FROM SCLADINA USED CAVE BEAR BONES AS RETOUCHERS
}

\section{Grégory Abrams ${ }^{1,2}$, Silvia M. Bello ${ }^{3}$, Kévin Di Modica ${ }^{1}$, Stéphane Pirson ${ }^{4} \&$ Dominique Bonjean ${ }^{1,2}$}

\author{
${ }^{1}$ Scladina Cave Archaeological Centre, Andenne (Belgium); gregory.abrams@scladina.be \\ ${ }^{2}$ Department of Prehistory, University of Liège, Liège (Belgium) \\ ${ }^{3}$ Department of Earth Sciences, Natural History Museum, London (England) \\ ${ }^{4}$ Direction of Archaeology, Public Service of Wallonia, Namur (Belgium)
}

Evidence of Neandertals using bear remains as knapping tools is rare. In this context, Scladina Cave (Belgium) collections prove to be an exceptional sample. In the sedimentary unit 5, which dates from MIS 5 ( $5 \mathrm{~d}$ to $5 \mathrm{~b}$ ), twenty-six bone retouchers have been identified. The morphology of the blanks and the knapping marks are comparable with bone retouchers found in other Middle Palaeolithic sites (Auguste, 2002; Jéquier et al., 2012; Mallye et al., 2012). Moreover, many lithic splinters found still embedded in the indentations and grooves confirm the use of these fragments as knapping instruments.

The refitting work which takes into account these retouchers and non-modified bones, helped to identify that six retouchers have been made from three cave bear bones (a right femur, a right and a left tibias). Among these retouchers, four (and two unused fragments) have been refitted together and reconstitute the almost complete right femur diaphysis. The presence of cut marks, scraping marks, impact notches and fractures typical of percussions on green/fresh bear bone fragments, points toward anthropogenic modifications.

The absence of carnivore tooth marks also suggests that Neandertals were the main, if not the only, agent responsible for their production. The anthropogenic marks also support the idea of the recovery of a still relatively fresh bear carcass or carcasses.

So far, no arguments support the idea of bear hunting or the scavenging of an individual in or close to Scladina Cave. The analysis of these exceptional remains increases the interest in the Scladina Cave collections and brings new insights into the use of bear bones by Neandertals. The numerous anthropogenic marks and their frequent overlapping allows for a clear interpretation of the operational sequence: disarticulation and defleshing of the bones (cut marks), fracturing (impact notches and breakage pattern), preparation (scrapping marks) and adjustment (negative flake scars).

The sophistication of the operational sequence where each action succeeds another in the production of a bone tool is a major argument in favor of predetermination that guided the Neandertal actions, and is similar to that described for the lithic reduction sequences.

\section{References}

Auguste P., 2002. Fiche éclats diaphysaires du Paléolithique moyen: Biache-Saint-Vaast (Pas-de-Calais) et Kulna (Moravie, République tchèque). In: Patou-Mathis M. (Ed.), Retouchoirs, compresseurs, percuteurs... Os à impressions et éraillures (Fiches de la Commission de nomenclature sur l'industrie de l'os préhistorique, cahier 10): 39-57.

JÉQuier C.A., RomANDini M. \& PERESANI M., 2012. Les retouchoirs en matières dures animales: une comparaison entre Moustérien final et Uluzzien. Comptes Rendus Palevol, 11: 283-292.

Mallye J.-B., Thiébaut C., Mourre V., Costamagno S., Claud É. \& Weisbecker P., 2012. The Mousterian bone retouchers of Noisetier Cave: experimentation and identification of marks. Journal of Archaeological Science, 39: 1131-1142. 


\title{
NEW CONTRIBUTION TO THE STUDY OF THE SMALL-VERTEBRATE ASSEMBLAGES OF SCLADINA Cave (late Pleistocene, province of Namur, Belgium)
}

\section{Hugues-Alexandre Blain ${ }^{1,2}$, Juan Manuel López-García ${ }^{3}$, Jean-Marie Cordy ${ }^{4}$, Stéphane Pirson ${ }^{5}$, Grégory Abrams $^{6,7}$, Kévin Di Modica ${ }^{6} \&$ Dominique Bonjean ${ }^{6,7}$}

\author{
${ }^{1}$ IPHES, Institut Català de Paleoecologia Humana i Evolució Social, Tarragona (Spain); hablain@iphes.cat \\ 2 Àrea de Prehistòria, Universitat Rovira i Virgili, Tarragona (Spain) \\ ${ }^{3}$ Sezione di Scienze Preistoriche e Antropologiche, Dipartimento di Studi Umanistici, Università degli Studi di Ferrara, Ferrara (Italy) \\ ${ }^{4}$ Musée de Zoologie, Liège (Belgium) \\ ${ }^{5}$ Direction of Archaeology, Public Service of Wallonia, Namur (Belgium) \\ ${ }^{6}$ Scladina Cave Archaeological Centre, Andenne (Belgium) \\ ${ }^{7}$ Department of Prehistory, University of Liège, Liège (Belgium)
}

The first studies on the small-vertebrate assemblages from Scladina Cave were undertaken by Jean-Marie Cordy and mainly focused on the rodents, insectivores and lagomorphs (Bastin et al., 1986; Cordy, 1992). The faunal list published in these first studies consists of some 21 taxa: 5 insectivores (Erinaceus europaeus, Talpa europaea, Sorex araneus, Sorex minutus and Crocidura sp.), 15 rodents (Lagurus lagurus, Citellus sp., Cricetulus migratorius, Sicista betulia, Lemmus lemmus, Dicrostonyx torquatus, Microtus arvalis-agrestis, Microtus gregalis, Microtus oeconomus, Chionomys nivalis, Microtus (Terricola) subterraneus, Arvicola amphibius, Myodes glareolus, Apodemus cf. sylvaticus and Glis glis) and one lagomorph (Ochotona pusilla). Presence of indeterminate chiropters and anurans were also mentioned.

The recent revision of Cordy's collections permits to add one insectivore (Neomys anomalus) and three bats (Myotis mystacinus s.l., Myotis cf. daubentonii and Barbastella barbastellus) to the former small mammal list of layers pertaining to MIS 5 (V ocre to VI), and M. mystacinus s.l. for layers VII and VIII (probably MIS 6-7). Amphibians and squamate reptiles are represented by three anurans (Pelodytes punctatus, Bufo bufo and Rana temporaria) for layers VII to X (probably MIS 6-7), one salamander (Salamandra salamandra), three anurans ( $P$. punctatus, $B$. bufo and $R$. temporaria), one lizard (Anguis fragilis) and two snakes (Zanemis longissimus and Vipera berus) for layers pertaining to MIS 5 (layers V ocre to VI) and one frog (Rana temporaria) and one lizard (Lacerta cf. agilis) for the layer I (MIS 3).

Of particular interest is the occurrence of the common parsley frog (Pelodytes punctatus) and the Aesculapian snake (Zanemis longissimus) that are not currently represented in Belgium. Scladina also represents one of the northernmost mentions for the fire salamander (Salamandra salamandra) although within its current distribution in Europe. Presence of the European adder (Vipera berus) is well attested in Scladina whereas today this snake is infrequent and classified as endangered in Belgium, probably due to anthropic pressure. All these new taxa fit well with warmer climatic conditions than current ones and with an environment composed by a still water stream within a forest area and laterally (probably on the overlying plateau) humid meadows.

\section{Acknowledgements}

This study is part of research project CGL2012-38358 of the Spanish Ministry of Economy and Competitiveness. JMLG is the beneficiary of a Beatriu de Pinós postdoctoral fellowship (2011BP-A00272) from the Generalitat de Catalunya, a grant co-funded by the European Union through the Marie Curie Actions of the $7^{\text {th }}$ Framework Program for R\&D.

\section{References}

BAstin B., Cordy J.-M., Gewelt M., \& OtTE M., 1986. Fluctuations climatiques enregistrées depuis 125.000 ans dans les couches de remplissage de la grotte Scladina (Province de Namur, Belgique). Bulletin de l'Association française d'étude du Quaternaire, $2^{\mathrm{e}}$ série, 25-26: 168-177.

CORDY J.-M., 1992. Bio- et chronostratigraphie des dépôts quaternaires de la grotte Scladina (province de Namur, Belgique) à partir des micromammifères. In: Otte M. (Ed.), Recherches aux grottes de Sclayn. Volume 1: Le Contexte (ERAUL 27): 79-125. 


\title{
Simple Prepared Cores and the Origins of LeVAllois
}

\author{
Lucie Bolton $^{1}$
}

\begin{abstract}
${ }^{1}$ Centre of the Archaeology for Human Origins (CAHO), Department of Archaeology, University of Southampton (UK); 1sb1g09@soton.ac.uk
\end{abstract}

From around 300,000 B.P. onwards hominins in Europe started producing flakes in a more systematic way. This core working technique, known as Levallois or Prepared Core Technology (PCT), has long been of interest to researchers; however, the origins of this technique are still highly debated. Fully developed Levallois reduction sequences seem to have their roots in a lesser studied technique referred to as either 'proto' Levallois, 'reduced' Levallois or more recently as Simple Prepared Core (SPC) technology.

This research represents the first comprehensive study comparing these techniques using a uniform methodology, bridging data from different sites in Britain and continental Europe. This paper presents results that demonstrate identical reduction techniques at all British sites allowing for the construction of a new overarching technological definition of SPC technology.
The material from Kesselt-Op de Schans and Mesvin IV will also be discussed in relation to this definition. Preliminary results would suggest an in situ development for SPC and the origins of Levallois from the Acheulean. This in turn potentially indicates independent complex hominin behavioural innovations rather than a single contiguous "tradition". 


\title{
The Middle Palaeolithic Site Of ReMicourt “En Bia Flo" I (LiÈge Province, BelgiUm)
}

\author{
Dominique Bosquet ${ }^{1}$, Paul Haesaerts ${ }^{2}$, Freddy Damblon ${ }^{2}$, Paula Jardón Giner ${ }^{3}$ \\ \& Caroline Ryssaert ${ }^{4}$
}

\footnotetext{
${ }^{1}$ Service de l'Archéologie, Direction extérieure du Brabant wallon, Service public de Wallonie, Wavre (Belgium); dominique.bosquet@spw.wallonie.be

2 Operational Direction "Earth and History of Life", Royal Belgian Institute for Natural Sciences, Brussels (Belgium)

${ }^{3}$ Departament de Prehistòria i Arqueologia, Universitat de València (Spain)

${ }^{4}$ Odin, Archeologisch Onderzoeks en Adviesbureau, Deinze (Belgium)
}

The site of Remicourt is located in the Hesbaye, on the HST line $15 \mathrm{~km}$ west of Liège, (Haesaerts et al., 1997, 1999), on an Upper Pleistocene loss ridge laying on Cretaceous substratum rich in flint. The Middle Palaeolithic site was excavated from November 1997 to April 1998 over an area of $624 \mathrm{~m}^{2}$ by the Direction de l'archéologie de la Région wallonne, in collaboration with the Royal Belgian Institute of Natural Sciences (Bosquet et al., 2004). Excavations recovered 438 lithic artefacts (including chips) preserved in the upper part of the "Sol de Rocourt", a soil complex corresponding to the Weichselian last interglacial and Early Glacial in the regional sequence (MIS 5; Haesaerts \& Mestdagh, 2000; Haesaerts et al., 1999). Lithic material is primarily distributed between two distinct spatial areas, concentrations $\mathrm{A}$ and $\mathrm{B}$. The lithics were abandoned at the site during a sedimentation phase preceding the formation of a gray forest soil around 87,000 B.P., during the cold episode which precedes the Dansgaard-Oeschger 21 interstade in the Greenland ice sequence (North Greenland Ice Core Project members, 2004), that is to say in MIS 5b. Stratigraphic analysis of the archaeological material and the detailed reconstruction of postdepositional phenomena (Bosquet \& Haesaerts, in press) allowed us to demonstrate a high degree of preservation of the archaeological layer, which is relatively rare for this period.

The lithic industry of Remicourt is exclusively made on flint, nine varieties of which have been recognised on the basis of macroscopic characteristics. Four of these varieties, corresponding to $90 \%$ of the worked material, were collected locally around the settlement (between 0 and $2 \mathrm{~km}$ ). These four principal flint types were worked according to six different chaînes opératoires: two laminar techniques, two based on flake production, a bifacial technique, and one based on tools production on natural supports.
Laminar production is characteristic of concentration A, while concentration $\mathrm{B}$ is characterised by a unidirectional technique exploiting as much as possible the morphology of the raw material blocks and focused on the production of robust, sometimes elongated flakes. In concentration $\mathrm{B}$, which does not include any laminar component, one also finds a bifacial leafy point and some tools made by retouching of raw blocks or pebbles on various types of flint.

The extremely good preservation of the lithics allowed use-wear analysis to be carried out on 180 artefacts from the two main concentrations. In addition to scraping and cutting, already known from other Middle Palaeolithic sites (Beyries, 1987a, b, 1993), the study identified slotting and drilling, as well a tool we label the "chisel", the use of which remains to be determined by experimentation. These tools were used to work primarily wood and some other unspecific hard matter, while working of skin and soft animal matter (meat, tendon, fresh or dry skin) was only occasionally identified.

An anthracologic analysis was also undertaken on 39 samples coming from the principal stratigraphic units. Carbonised elements collected by wet sieving are for the most stratigraphically associated with the lithic industry and where concentrated in a $2 \mathrm{~m}^{2}$ area of concentration B. 424 small fragments ( $2 \mathrm{~mm}$ to $1 / 4 \mathrm{~mm}$ ) were collected, including 214 fragments of carbonized spongy bone, 34 fragments of compact bone and 176 pieces of charcoal, mainly from spruce (Picea sp.), juniper (Juniperus sp.), pine (Pinus type sylvestris), birch (Betula) and unspecified herbaceous Monocotyledons. The assemblage thus presents a clear boreal character, fully consistent with the chronostratigraphy. The preservation state, the proportions and the spatial distribution of carbonized remains suggest the presence in 
concentration B of one or more hearth(s), fuelled with a mixture of green, wet wood, deadwood, and fresh spongy bones. The adjunction of bones allows to combine duration and intensity of the hearth(s) (Théry-Parisot et al., 2005).

\section{References}

BEYRIES, S., 1987a. Quelques exemples de stigmates d'emmanchement observés sur des outils du Paléolithique moyen. In: Stordeur, D. (Ed.), La Main et l'Outil: manches et emmanchement préhistoriques, Table ronde du CNRS. Paris, Maison de l'Orient: 55-63.

BEYRIES, S., 1987b. Variabilité de l'industrie lithique au Moustérien: approche fonctionnelle sur quelques gisements français (BAR International Series 328), $204 \mathrm{p}$.

BEYRIES, S., 1993. Analyse fonctionnelle du niveau CA: rapport préliminaire et direction de recherche. In: Tuffreau, A. (Ed.), Riencourt-lès-Bapaumes (Pas-de-Calais). Un gisement du Paléolithique moyen (Documents d'Archéologie Française, 37): 53-61.

BosQuet, D. \& HAESAERTS, P. (Ed.), [in press]. Remicourt “En Bia Flo” I: site paléolithique moyen de plein air (province de Liège, Belgique) (Études et Documents - Archéologie)

BosQuet, D., JARDón Giner, P. \& JADIN, I., 2004. L'industrie lithique du site paléolithique moyen de Remicourt "En Bia Flo" (province de Liège, Belgique): technologie, tracéologie et analyse spatiale. In: Van Peer P., Semal P. \& Bonjean D. (Eds), Actes du XIV Congrès de l'UISPP, Université de Liège, Belgique, 2-8 septembre 2001. Section 5. Le Paléolithique moyen. Sessions générales et posters (BAR International Series 1239): 257-274.

HAESAerts, P. \& Mestdagh, H., 2000. Pedosedimentary evolution of the last interglacial and early glacial sequence in the European lœss belt from Belgium to central Russia. Geologie en Mijnbouw, 79: 313-324.

Haesaerts, P., Mestdagh, H. \& Bosquet, D., 1997. La séquence lossique de Remicourt (Hesbaye, Belgique). Notae Praehistoricae, 17: 45-52.

Haesaerts, P., Mestdagh, H. \& Bosquet, D., 1999. The Sequence of Remicourt (Hesbaye, Belgium): New Insights on the Pedo- and Chronostratigraphy of the Rocourt Soil. In: Baeteman C. (Ed.), Quaternary Geology of Belgium: New Perspectives. Geologica Belgica, 2 (1-2). Bruxelles: 5-27.

North GREENLAND ICE CORE ProjeCt MEMBERS, 2004. High-resolution record of Northern Hemisphere climate extending into the last interglacial period. Nature, 431: 147-151.

Théry-PARisot, I., Costamagno, S., Brugal, J.-P., Fosse, P. \& Guilbert, R., 2005. The use of bone as fuel during the palaeolithic, experimental study of bone combustible properties. In: Mulville J. \& Outram A. K. (Eds), The Zooarchaeology of Fats, Oils, Milk and Dairying, $200 \mathrm{p}$ 


\section{IN THE FOOTSTEPS OF THE NEANDERTHALS AT ROZEL (MANCHE), ABOUT 110,000 YEARS AGO}

\section{Dominique Cliquet ${ }^{1,2}$, Philippe Alix ${ }^{3}$, Patrick Auguste ${ }^{4}$, Jean-Pierre Coutard ${ }^{1}$, Émeline Deneuve ${ }^{1}$, Agnès Gautier ${ }^{5}$, Norbert Mercier ${ }^{6}$, Nancy Marcoux ${ }^{2}$, Olivier Moine ${ }^{5}$, Hugues Plisson ${ }^{7,8}$, Philippe Ponel $^{9}$, Emmanuelle Stoetzel $^{10}$, Élisabeth Tribouillard ${ }^{1}$ \& Brigitte Van-Vliet Lanoë ${ }^{11}$}

\footnotetext{
${ }^{1}$ Service régional de l'archéologie de Basse-Normandie, Caen (France); dominique.cliquet@gmail.com

${ }^{2}$ UMR 6566 CNRS, Université de Rennes I, CReAAH, Rennes (France)

${ }^{3}$ INRAP Rhône, Alpes, Auvergne, Bron (France)

${ }^{4}$ UMR 8217 CNRS, Université Lille 1, Laboratoire "Géosystèmes, Villeneuve d'Ascq (France)

${ }^{5}$ UMR 8591 CNRS, Université Paris I, Laboratoire de Géographie Physique, "Environnements quaternaires et géoarchéologie", Meudon (France)

${ }^{6}$ UMR 5060 CNRS, Université Bordeaux 3, Maison de l'Archéologie, Centre de recherche en physique appliquée à l'archéologie, Pessac

${ }^{7}$ UMR 5199 CNRS, Université Bordeaux 1, Laboratoire PACEA, Talence (France)

${ }^{8}$ Pôle mixte de recherche archéologique de Campagne (France)

${ }^{9}$ UMR 7263 CNRS, Aix-Marseille Université, Aix-en-Provence (France)

${ }^{10}$ UMR 7205 CNRS, Museum National d'Histoire Naturelle, Département Systémique et évolution, Paris (France)

${ }^{11}$ UMR 6538 CNRS, Institut écologie et environnement, Institut universitaire européen de la mer, Observatoire des sciences de l’univers, Université de Bretagne occidentale, Plouzané (France)
}

The resumption of excavations on the site of Rozel (Manche) in 2012, identified several occupation levels in the Weischelian dune which correspond to areas of butchery dated by OSL to $110 \mathrm{ky}$.

The major interest of the deposit is the exceptional state of preservation of the levels and remains related to anthropogenic activities (hearths and emptying hearths that contain charcoal remains but also burned bone, flint and quartz, and the bones of large mammals consumed). Besides charcoal, many elements allow a fine approach to the environment of the dune (molluscs, micro-fauna, insects, amphibians, crustaceans, fish and birds) to be made.

On the two levels analysed, activities were structured around hearths which functioned directly at ground level, supplied with wood (mainly conifers) and spongy bone. Anvils of quartz and of schist and slabs of slate were placed on the floor. These slabs are currently interpreted as dishes to isolate meat from the sandy soils.

On both occupation levels, the remains of large animals are abundant (red deer, aurochs, horse and more anecdotal, roe deer and rhino) that attest the processing of carcasses (cut marks, spiral fracture of long bones to extract the marrow).
In this area dedicated to butchery and probably to the processing of meat to ensure its conservation (hearths), the lithic assemblage comprises essentially quartz from natural veins and especially flint from submarine deposits.

If some Levallois cores upon which several flakes discovered connect, most of the lithic assemblage consists of scrapers that have been sharpened as and when they were used by bone retouchoirs (fragments of diaphyseal femur and tibia of deer). These different "sharpening stations" allow us to understand more clearly work sequencing on the area of activity. Finally, the excavation of both levels has produced the footprints of Neanderthals for which the modules attest the presence of adults, adolescents and children on the site. This would argue for the movement of at least one part of a group (all age groups combined) for the acquisition of meat at the beginning of the last glaciation in the Cotentin. 


\title{
LITHIC TECHNOLOGIES AMONG THE LATE NEANDERTAL POPULATIONS OF THE MEUSE BASIN: SClADINA CAVE MIS 3 ARCHAEOLOGICAL COMPLEX AS A CASE STUDY.
}

\author{
Justin Coppe ${ }^{1}$, Dominique Bonjean ${ }^{1,2}$ \& Kévin Di Modica²
}

\footnotetext{
${ }^{1}$ Department of Prehistory, University of Liège, Liège (Belgium); justincoppe@ $@$ hotmail.com

${ }^{2}$ Scladina Cave Archaeological Centre, Andenne (Belgium)
}

Scladina Cave has yielded multiple archaeological assemblages ranging from MIS 5 to MIS 3 (Bonjean et al., 2011). The MIS 3 lithic material, mainly associated with the sedimentary unit $1 \mathrm{~A}$ (37-40 ky uncal B.P., Pirson et al. 2008), has been subject to several technological studies (Di Modica, 2010; Loodts, 1998; Moncel, 1998) that have led to various interpretations.

Our study aims at re-evaluating this archaeological complex through of an extensive refitting program. More than 3000 flint artefacts coming from an area as large as c. $250 \mathrm{~m}^{2}$ have been included 130 refits were obtained, each comprising 2-12 items.

These refits provide information about the morphology and the origin of the blanks selected for knapping activities as well as the reduction strategies used. Neandertals favored locally available raw material. They mainly collected elongated, $5-10 \mathrm{~cm}$ long pebbles of poor quality flint available in the Meuse alluvial deposits (Horevoets, 2013). The debitage is récurrent, mainly on one surface. The reduction sequences are taking advantage of the natural convexities of the pebbles in order to limit the core preparation and to maximize the cutting edge production. The knapping sequences are characterized by an adjustment of the technology to the elongated morphology of the pebbles, which led into a reduced amount of waste but also to a lack of standardization in flake production.

The refitting program shows that MIS 3 Neandertals in Scladina preferred the exploitation of local mineral resources and adapted their technological behaviour to the morphometric constraints of the blanks, while better flint sources were available 6 to $30 \mathrm{~km}$ north of the site. Such a trend of exploiting close-to-site resources is commonly observed at Mousterian sites in Belgium (Di Modica, 2010). Our study shows that this trend is still persists among Late Neandertals around $37-40$ ky uncal B.P. and clearly contrasts with the AMH lithic exploitation strategies documented at Aurignacian sites in Belgium.

\section{References}

Bonjean D., Di Modica K., Abrams G., Pirson S. \& Otte M., 2011. La grotte Scladina: bilan 1971-2011. In: Toussaint M., Di Modica K. \& Pirson S. (Dir.), Le Paléolithique moyen en Belgique. Mélanges Marguerite Ulrix-Closset (ERAUL 128, Bulletin des Chercheurs de la Wallonie Hors-série No 4), 323-334.

Di Modica K., 2010. Les productions lithiques du Paléolithique moyen de Belgique: variabilité des systèmes d'acquisition et des technologies en réponse à une mosaïque d'environnements contrastés. Ph.D. Dissertation, Université de Liège - Museum National d'Histoire Naturelle, $787 \mathrm{p}$.

HoREVOETS M., 2013. La pétroarchéologie du silex ou comment retracer les gîtes d'approvisionnement en matières premières utilisés par l'homme préhistorique en Belgique ? État de l'art, discussions méthodologiques et application à l'ensemble sédimentaire 1A de Scladina (Sclayn, province de Namur). Mémoire inédit de Maîtrise en Histoire de l'Art et Archéologie, orientation Archéométrie, finalité approfondie. Université de Liège, 2 volumes, 137 p. \& 103 p.

LOODTS I., 1998. Une approche comportementale de l'Homme de Neandertal. L'industrie lithique de la couche 1A de la grotte Scladina, économie des matières premières et coexistence des chaînes opératoires au Paléolithique moyen récent. In: Otte M., Patou-Mathis M. \& Bonjean D. (Eds), Recherches aux grottes de Sclayn. Volume 2. L'Archéologie (ERAUL 79): 69-101.

Moncel, M.-H., 1998. L'industrie lithique de la grotte Scladina (Sclayn). La couche moustérienne 1A. In: Otte M., Patou-Mathis M. \& Bonjean D. (Eds), Recherches aux grottes de Sclayn. Volume 2. L'Archéologie (ERAUL 79): 103-112.

Pirson, S., Court-Picon, M., Haesaerts, P., Bonjean, D. \& Damblon, F., 2008. New Data on Geology, Anthracology and Palynology from the Scladina Cave Pleistocène Sequence: Preliminary Results. In: Damblon F., Pirson S. \& Gerrienne P. (Eds), Hautrage (Lower Cretaceous) and Sclayn (Upper Pleistocene). Field Trip Guidebook of the IVth International Meeting of Anthracology (Royal Belgian Institute of Natural Sciences, 8-13 September 2008). Charcoal and Microcharcoal: Contiental and Marine Records (Memoirs of the Geological Survey of Belgium 55): 71-93. 


\title{
MULTIPROXY RECORD OF ENVIRONMENTAL AND CLIMATIC VARIATIONS DURING THE MIS 5E Middle PAlaEolithic OCCUPATION AT CAOURS (NORTHERN FRANCE): COMBINING PETROGRAPHY, MALACOLOGY AND TUFA GEOCHEMISTRY
}

\section{Julie Dabkowski ${ }^{1}$, Nicole Limondin-Lozouet ${ }^{1}$, Pierre Antoine ${ }^{1}$, Jean-Luc LOCHT ${ }^{1,2}$, Julian Andrews ${ }^{3}$, Christine Chaussé 1 , Pierre Carbonel ${ }^{4} \&$ Alina Marca-Bell $^{3}$}

\author{
${ }^{1}$ UMR 8591 CNRS, Université Paris I, Laboratoire de Géographie Physique, "Environnements quaternaires et géoarchéologie", \\ Meudon (France); dabkowski@mnhn.fr \\ 2 INRAP Nord-Picardie, Amiens (France) \\ ${ }^{3}$ School of Environmental Sciences, University of East Anglia, Norwich (UK) \\ ${ }^{4}$ UMR 5805 CNRS, EPOC, Université Bordeaux 1, Talence (France)
}

New investigations in the River Somme basin have allowed the discovery of an exceptionally well preserved calcareous tufa formation overlying an alluvial sequence at Caours (Scardon valley). The whole calcareous tufa sequence is attributed to the Eemian Interglacial (MIS 5e) according to its location on the lowest terrace within the Somme terrace system, palaeontological data, and U/Th TIMS dating on well crystallised samples as stromatoliths and oncoliths (average of $124 \pm 4 \mathrm{ky}$ B.P.). The alluvial sequence is composed by periglacial gravels overlain by fluvial calcareous silts then a marshy soil and a thin peat layer. At least four distinct archaeological levels have been evidenced in the sequence: one in the upper part of the calcareous silts, one at the surface of the peat layer and two within thin organic tufa horizons included in the base of the calcareous tufa deposit. To precise the environmental and climatic context of these Middle Palaeolithic occupations, data from a petrographic study and molluscs were compared to geochemical proxies recording temperature $\left(\delta^{18} \mathrm{O}\right)$ and humidity $\left(\delta^{13} \mathrm{C}\right.$ and trace elements $\mathrm{Mg}$ and $\mathrm{Sr}$ ).

In thin section, the calcareous silt presents thin organic bioturbated horizons corresponding to floodplain soil development contemporaneous to the archaeological level. The organic facies of the overlying peat layer is specific of peat deposit in anoxic conditions. Fragments of coprolites are observed and demonstrate occurrence of at least one drying phase, allowing occupation of the site. In the upper part of the silts and the peat layer, open forest environments of the early Interglacial, consistent with the sedimentological and petrographical observations, are recorded by mollusc assemblages.

Petrographic observations of tufa aim to identify the main Cyanobacteria taxa precipiting calcite. The fossil genus Broutinella and Ponsinella are dominant. Broutinella built massive "cauliflower" tufas. This subaqueous facies is associated with aquatic molluscs and ostracods. Ponsinella produces the "mille-feuilles" facies with thin laminations testifying of diffuse flow periods. This facies is related with malacofaunas dominated by land snails and correlated to the two main archaeological levels at the very base of the tufa. The "mille-feuilles" facies is actually better developed in the upper part of the sequence as spring flow waned, and drier conditions are recorded by the $\delta^{13} \mathrm{C}$ data and mollusc fauna. The cauliflower facies is dominant in the lower part of the sequence, where more pluvial conditions are suggested by $\delta^{13} \mathrm{C}$ data. This wettest part is also the warmest according to $\delta^{18} \mathrm{O}$, and corresponds to the expansion of woodland molluscs. The maxima of temperature and humidity (from $\delta^{18} \mathrm{O}$ and $\delta^{13} \mathrm{C}$ ) are correlated with the highest numbers of shells and forest species. They also include the two main archaeological levels. The Middle Palaeolithic occupations thus occurred during the Climatic Optimum, at some times while the water flow from springs was lower, allowing relative drying of the tufa surface and its appropriation by humans. 


\section{Reference}

Antoine P., Limondin-Lozouet N., Auguste P., Locht J.L., Ghaleb B., Reyss J.L., Escudé E., Carbonel P., Mercier N., Bahain J.-J., FAlguères C. \& Voinchet P., 2006. Le tuf de Caours (Somme, Nord de la France): mise en évidence d'une séquence de tufs calcaires eemiens et d'un site paléolithique associé. Quaternaire 17 (4): 281-320.

DABKowski J. et al., 2010. Les microfaciès du tuf calcaire éemien (MIS 5e) de Caours (Somme, France): éléments d'analyse paléoéocologique du dernier interglaciaire. Quaternaire, 21 (2): 127-137.

DABKowski J., LimOndin-Lozoutet N., ANTOINE P., MARCA-Bell A., \& ANDREWs J., 2011. Enregistrements des variations climatiques au cours des interglaciaires pléistocènes d'après l'étude des isotopes stables de la calcite des tufs calcaires. Quaternaire, 22 (4), 275-281.

LimONDin-LOzOUET N. et al., 2014. Neandertal occupation during MIS 5e at Caours (Northern France): a multidisciplinary study. This volume. 


\title{
CT SCANNING: \\ IS IT TRULY NON-DESTRUCTIVE?
}

\section{Isabelle De Groote ${ }^{1}$, Chris Stringer ${ }^{2}$, Cia Anderung ${ }^{3}$, Tom Higham ${ }^{4}$, Rob Kruszynski $^{2} \&$ Rhiannon $^{5}$ Stevens ${ }^{5}$}

\author{
${ }^{1}$ John Moores University, Liverpool (UK); idegroote@yahoo.com \\ ${ }^{2}$ The Natural History Museum, London (UK) \\ ${ }^{3}$ Dept of Evolutionary Biology, Uppsala University (Sweden) \\ ${ }^{4}$ School of Archaeology, University of Oxford (UK) \\ ${ }^{5}$ McDonald Institute for Archaeological Research, University of Cambridge (UK)
}

With the recent advances in three-dimensional (3D) imaging techniques, archaeologists and palaeoanthropologists now frequently use computed tomography (CT) to study bone, antler and tooth specimens. CT uses X-ray transmission to produce density maps of specimens, which can be used to create 3D models that can be virtually sectioned and manipulated. Because it allows for virtual studies of the objects, the method is often described as non-destructive. The ability to apply $\mathrm{CT}$-scanning to a range of materials and at different resolutions means that it is now possible to study a wide variety of specimens (Bello et al., 2013; Smith et al., 2010; Zollikofer et al., 2005). Also, for conservation reasons, curators are actively seeking to create virtual models of their fossils that can be distributed to scientists electronically, rather than risk damage to the specimens from repeated handling. Preferably, scanning would be performed before any destructive sampling occurs in order to provide a scan to researchers without evidence of sampling holes. The increased portability and availability of $\mathrm{CT}$-scanners has meant that an increasing number of fossils are now being CTscanned. Even greater resolution is offered by micro-CT scanners than hospital based conventional CT scanners, but these are also more likely to expose the specimens to higher dose-rates. Small objects, especially those placed closer to the
X-ray tube, will receive a greater dose of radiation compared to objects further away from the tube.

Despite its reputation as a non-destructive sampling technique, recent studies have suggested that X-rays may fragment DNA molecules in living tissue (Grieshaber et al., 2008; Paredes et al., 2012; De Groote et al. in prep; Tafforeau, personal communication) and that it may affect ESR dating when micro-CT scanning teeth (Grün et al., 2012).

This study sets out to test a number of frequently used CT scanning protocols on animal bone to test the effect of CT scanning on analyses such as ${ }^{14} \mathrm{C}$ dating, ancient DNA and stable isotopes. The results indicate that there is no effect of CT scanning on the accuracy of ${ }^{14} \mathrm{C}$ dating. In contrast, CT scanning does have a significant effect on the amount of preserved DNA and DNA fragment length and stable isotope results are expected in the near future.

The experimental work in this study has highlighted the need to create a Best Practice protocol for CT scanning that would involve scanning with filters and removing samples from specimens before scanning, in order to obtain the most accurate/least affected results.

\section{References}

Bello, S., De Groote, I. \& Delbarre, G., 2013. Application of 3-dimensional microscopy and micro-CT scanning to the analysis of Magdalenian portable art on bone and antler. Journal of Archaeological Science, 40: 2464-2476.

Grieshaber, B. M., Osborne, D. L., Doubleday, A. F. \& Kaestle, F. A., 2008. A pilot study into the effects of X-ray and computed tomography exposure on the amplification of DNA from bone. Journal of Archaeological Science, 35, 681-687.

GrÜN, R., Athreya, S., RAJ, R. \& PATnAiK, R., 2012. ESR response in tooth enamel to high-resolution CT scanning. Archaeological and Anthropological Sciences, 4: 25-28.

Paredes, U. M., Prys-Jones, R., Adams, M., Groombridge, J., Kundu, S., Agapow, P.-M. \& Abel, R. L., 2012. Micro-CT X-rays do not fragment DNA in preserved bird skins. Journal of Zoological Systematics and Evolutionary Research, 50: 247-250.

Smith, T. M., Tafforeau, P., Reid, D. J., Pouech, J., Lazzari, V., Zermeno, J. P., Guatelli-Steinberg, D., Olejniczak, A. J., Hoffman, A., RadovČić, J., Makaremi, M., Toussaint, M., Stringer, C. \& Hublin, J.-J., 2010. Dental evidence for ontogenetic differences between modern humans and Neanderthals. Proceedings of the National Academy of Sciences, 107: 20923-20928.

Zollikofer, C. P., De Leon, M. S. P., Lieberman, D. E., Guy, F., Pilbeam, D., Likius, A., Mackaye, H. T., Vignaud, P. \& Brunet, M., 2005. Virtual cranial reconstruction of Sahelanthropus tchadensis. Nature, 434: 755-759. 


\title{
Walou CAVE (Trooz): \\ AN EXCEPTIONAL SEQUENCE FROM THE BELGIAN PALAEOLITHIC
}

\section{Christelle Draily ${ }^{1}$, Stéphane Pirson ${ }^{2}$, Mona Court-Picon ${ }^{3}$, Wim Van Neer ${ }^{3}$, Wim Wouters $^{3}$, Bjorn De Wilde $^{4}$, Nick Debenham ${ }^{5}$, Freddy Damblon ${ }^{3} \&$ Michel Toussaint $^{2}$}

\author{
${ }^{1}$ Service de l'Archéologie, Direction extérieure du Luxembourg, Service public de Wallonie, Arlon (Belgium); \\ Christelle.draily@spw.wallonie.be \\ 2 Direction of Archaeology, Public Service of Wallonia, Namur (Belgium) \\ ${ }^{3}$ Operational Direction "Earth and History of Life", Royal Belgian Institute for Natural Sciences, Brussels (Belgium) \\ ${ }^{4}$ Laarne (Belgium) \\ ${ }^{5}$ Quaternary TL Survey, Nottingham (UK)
}

Located some $10 \mathrm{~km}$ at the south-east of Liège the Walou cave entrance faces the north-west, $25 \mathrm{~m}$ above the Magne, a tributary of the Vesdre river. Excavations were conducted at the site from 1985 to 1990 and then from 1996 to 2004, revealing numerous successive prehistoric occupations. Its extensive stratigraphic sequence is the best documented for a Belgian Upper Pleistocene karst site. Thanks to a multidisciplinary approach the chronostratigraphic and palaeoenvironmental framework of the occupations is well understood.

Out of the 45 layers of the sequence 25 yielded archaeological material. There are traces of the Neolithic (Layer A2) and the Mesolithic (Layers A4 and A5) at the top. The cave also revealed several Upper Palaeolithic occupations: Federmesser (Layer B1), Gravettian (Layer B5) and Aurignacian (Layer CI-1). The lower half of the sequence, which encompasses the Last
Interglacial and the Weichselian Early Glacial, includes 9 Mousterian occupations; 6 reworked layers also yielded some artefacts from that culture. A Neandertal tooth was found in Layer CI-8, which contains the richest Mousterian occupation of the site. All lithic material was made from flint probably sourced in secondary position near the cave. Only the Gravettian and Aurignacian occupations yielded other man-made materials: antler spearheads and animal and mineral nonutilitarian artefacts from the Aurignacian. Numerous faunal remains were also found; among them: cave bear, cave hyena, horse, fox, bison/aurochs, woolly rhinoceros, deer, mammoth, chamois, hare, small rodents and a few birds. The study of the fish remains revealed that fishing took place at the site, as much during the Middle Palaeolithic as during the Upper Palaeolithic and Neolithic. 


\title{
CONTEXTUALISING VOLUMETRIC LAMINAR STRATEGIES IN NORTH-WEST EUROPE BEFORE C. 120,000 B.P.: AN INTER-REGIONAL STUDY
}

\section{Christian S. Hoggard ${ }^{1}$}

\begin{abstract}
${ }^{1}$ Centre of the Archaeology for Human Origins (CAHO), Department of Archaeology, University of Southampton (UK); C.Hoggard@soton.ac.uk
\end{abstract}

Laminar technology in the Middle Pleistocene is a much understudied topic and sites featuring this technology have been poorly analysed on a larger scale. This poster summarises the European evidence for laminar technology, before the Late Middle Palaeolithic (c.120,000 B.P.) and inter/intra-site analyses, undertaken by the author, to account for their origins and significance, in Europe and worldwide. The research suggests there are at least two independent occurrences with the initial appearance (c. 545,000-450,000 B.P.) representing a localised in situ innovation developing from parallel core management strategies. These appear localised, fragmented and short-term given the nature of social structures within the Lower Palaeolithic. A 100,000 year period of absence then follows before an influx of sites, throughout Europe and Western Asia, contemporaneous with the widespread use of Levalloisian technology, lasting from c. 350,000 B.P. until the end of the Middle Pleistocene. In Europe and Africa laminar products can be viewed as "expedient" tools - unstandardised and unretouched blades produced from local raw material. This contrasts laminar products from Western Asia which appear "curated" in nature, retouched and standardised with more time and energy invested. Laminar technology can be viewed as an advantageous technological strategy when compared with Levalloisian technology, regarding the standardisation of blank thickness, cutting-edge and shape; these advantages may explain its widespread use c. 350,000 B.P. 


\title{
RAW MATERIAL PROCUREMENT STRATEGIES AMONG THE BELGIAN LATE NEANDERTHALS: THE CASE OF SCLADINA CAVE'S MIS 3 ARCHAEOLOGICAL DEPOSITS
}

\author{
Michael Horevoets ${ }^{1}$, Kévin Di Modica ${ }^{2}$, Stéphane Pirson $^{3}$ \& Étienne Juvigné ${ }^{4}$
}

\footnotetext{
${ }^{1}$ Department of Prehistory, University of Liège, Liège (Belgium); michaelhorevoets@yahoo.fr

${ }^{2}$ Scladina Cave Archaeological Centre, Andenne (Belgium)

${ }^{3}$ Direction of Archaeology, Public Service of Wallonia, Namur (Belgium)

${ }^{4}$ Department of Geography, University of Liège (Belgium)
}

Studies of Neandertal raw material procurement strategies usually indicate the preferential use of raw materials available in the vicinity of the site $(<5 \mathrm{~km})$. Those local materials generally represent between 70 and $98 \%$ of the collections (i.e. Geneste, 1989).

In Scladina Cave's MIS 3 archaeological material (unit 1A), Cretaceous flint represents the $2 / 3$ of the raw material (Di Modica, 2010). According to the Geological Map, the closest possible Cretaceous outcrops lies $8 \mathrm{~km}$ north as the crow flies. In the immediate surroundings of the cave, Carboniferous limestone and cherts from the geological substratum as well as quartz and quartzite river pebbles from the Meuse alluvial deposits were also collected. Therefore, the MIS 3 archaeological deposits in Scladina Cave were previously presented as an exception within the Middle Palaeolithic framework as most of the raw materials were considered as transported from at least $6 \mathrm{~km}$ from the site (Loodts, 1998). These conclusions were questioned in a recent study (Di Modica, 2010), arguing that part of the Cretaceous flint has cortex with wear suggesting acquisition in alluvial deposits. The Meuse has been pointed out as a hypothetical source for these flint river pebbles. Such pebbles have however never been described in the archaeological literature for the Meuse alluvial deposits in the surroundings of Scladina Cave.
In order to test this absence, several secondary deposits such as Meuse alluvial terraces and residual Cretaceous outcrops (flint clays) were investigated in the immediate vicinity of the site, and the literature has been reviewed (see Horevoets, 2013). For the first time, systematic field survey by a multidisciplinary team was undertaken with an archaeological objective. This led us to the discovery in several alluvial terraces of flint river pebbles similar in size and cortex aspect to those represented in the archaeological material from Scladina. These results indicate that the types of flint river pebbles used by Neandertals were still actually present not far from the cave. Therefore, there is no longer any reason to consider the Scladina $1 \mathrm{~A}$ raw materials as mainly imported, leading to a reinterpretation of the raw material procurement strategies by Scladina's MIS 3 Neandertals that is more consistent with the general framework known for the Middle Palaeolithic.

Our study indicates that the importance of secondary and residual outcrops in Neandertal raw material procurement strategies has been largely underestimated in Belgium. The identification and survey of these types of outcrops are promising and still need to be done on a larger scale. This could lead to a better understanding of Neandertal mineral territorial management and economic behaviour on Belgian territory.

\section{References}

Di Modica K., 2010. Les productions lithiques du Paléolithique moyen de Belgique: variabilité des systèmes d'acquisition et des technologies en réponse à une mosaïque d'environnements contrastés. Ph.D. Dissertation, Université de Liège - Museum National d'Histoire Naturelle, $787 \mathrm{p}$.

GENESTE J.-M., 1989. Économie des resources lithiques dans le moustérien du sud-ouest de la France. In: Otte M. (Ed.), L'Homme de Néandertal, vol. 6, La subsistance (ERAUL 33): 75-97.

HoREVOETS M., 2013. La pétroarchéologie du silex ou comment retracer les gîtes d'approvisionnement en matières premières utilisés par l'homme préhistorique en Belgique ? État de l'art, discussions méthodologiques et application à l'ensemble sédimentaire 1A de Scladina (Sclayn, province de Namur). Mémoire de Maîtrise en Histoire de l'Art et Archéologie, Université de Liège, 1 volume de texte (137 pages), 1 volume d'illustrations (103 pages).

LOODTS I., 1998. Une approche comportementale de l'Homme de Neandertal. L'industrie lithique de la couche 1A de la grotte Scladina, économie des matières premières et coexistence des chaînes opératoires au Paléolithique moyen récent. In: Otte M., Patou-Mathis M. \& Bonjean D. (Eds), Recherches aux grottes de Sclayn. Volume 2. L'Archéologie (ERAUL 79): 69-101. 


\title{
The Middle Palaeolithic In EASTERn France: CHARACTERISTICS AND COMPARISONS WITH NEIGHBOURING COUNTRIES
}

\author{
Agnès Lamotte ${ }^{1}$
}

${ }^{1}$ UMR 8164 CNRS, Halma-Ipel, Université de Lille 1, Villeneuve d'Ascq (France); lamotteagnes@orange.fr

Past excavations in Eastern France have focussed almost exclusively on cave localities, often neglecting open-air sites. Large-scale state-funded construction works of motorways or TGV-lines were also not undertaken in this part of France. Since 2005, however, we have obtained several excavation permits to undertake work at different open-air sites within this region. This work has permitted new observations regarding lithic and technologic features and to discuss and compare these with neighbouring countries (Belgium, Germany, Switzerland), and in the future also with Eastern Europe. Many of the lithic industries are surface collections with only a few related to an exceptionally well-preserved MIS 3 stratigraphy. Bifaces are common along with simple sidescrapers. The Levallois method dominates, but other reduction sequences such as laminar, discoid, SSDA or Quina systems are also present. It can be concluded that many of these eastern French industries have points of commonality with the Mousterian with bifacial tools (MBT) or with the Keilmessergruppen (KMG), underlining how this region was a crucial East-West axis for population movement in Europe. 


\title{
News from the North. A Middle Palaeolithic Site Rich in handaXes On the Drenthe PlATEAU, THE NORTHERN NETHERLANDS: FIRST RESULTS OF A TRIAL EXCAVATION
}

\author{
Marcel J.L.Th. Niekus ${ }^{1}$ \& Dirk Stapert ${ }^{1}$
}

\footnotetext{
${ }^{1}$ Lopendediep 28, 9712 NW Groningen (The Netherlands); marcelniekus@gmail.com

${ }^{2}$ Ossewei 6, 9751 SC Haren (The Netherlands)
}

In the spring of 2007 a Middle Palaeolithic surface scatter was discovered in a field not far from the city of Assen, in the province of Drenthe. This discovery was one of the results of systematic field surveys carried out by archaeology students and (amateur) archaeologists under supervision of the Groningen Institute of Archaeology and the Drents Museum in Assen. Since then, more than 80 Middle Palaeolithic flint artefacts were collected, at least half of which occurred within an area measuring c. $40 \times 30 \mathrm{~m}$. During the winter of 2011 a trial excavation was carried out; the main goal was to establish the stratigraphical position of the artefacts. Several test-pits were excavated and hundreds of square metres of topsoil were sieved. For the first time in the northern Netherlands, Middle Palaeolithic artefacts were found in situ: in bouldersand, a weathering residue of glacial till mixed with coversand and preglacial sand as a result of cryoturbation and aeolian action over a long period of time. The find level itself is heavily cryoturbated. In total, more than 400 artefacts were found, consisting of flakes, blades, cores and tools. Among the tools especially handaxes occur, other types being rare. Apart from flints, artefacts made of quartzite, quartzitic sandstone and hälleflinta are also present. Several refits point to the relatively undisturbed character of the site. Although not all finds have yet been studied in detail, it is clear that most of the handaxes were brought to the site in a semi-finished or finished state; only a few chips could be refitted to handaxes. Handaxe-flakes point to the production or finishing of a number of handaxes on the site, including several made by one or a few apprentices in the art of flint knapping. Based on the typological characteristics of the handaxes (triangular and cordiforme shapes) the site is attributed to the Mousterian of Acheulian Tradition (MAT), Type A, with an approximate age of 50,000 to 100,000 years. There are no dates for the site yet, but a few sediment samples have been submitted for OSL-dating. The site is located near a stream valley along which quite a lot of Middle Palaeolithic sites are known; a few kilometers to the east, a site with several preforms of leaf points was discovered. 


\title{
LA CotTe de ST. BRELADE (JERSEY): RE-EVALUATING NEANDERTHAL SUBSISTENCE BEHAVIOUR AND LANDSCAPE USE
}

\author{
Geoff M. Smith ${ }^{1}$
}

\begin{abstract}
${ }^{1}$ MONREPOS Archaeological Research Centre and Museum of Human Behavioural Evolution. Schloss Monrepos, Neuwied (Germany); $\underline{\text { smith@rgzm.de }}$
\end{abstract}

La Cotte de St. Brelade (CSB, Jersey) is one of the most prolific Middle Palaeolithic localities in Western Europe (ca. 96,000 lithic and 1,500 faunal remains). Extensive fieldwork (1890-1980) exposed deposits representing 250,000 years of shifting climates and environments. Since publication of the CSB monograph (Callow \& Cornford, 1986), the interpretation of the site as a mammoth drive locality (Scott, 1980, 1986) has remained a unique, if untested, hypothesis regarding Neandertal subsistence strategies and landscape use. This interpretation is based on the analyses of two distinct "bone heap" levels (Units 3 and 6), composed almost entirely of megafaunal remains. Presently, such structured and repetitive subsistence behaviour has been suggested, but never concisely argued, for any other European Middle Palaeolithic site, calling for a re-evaluation of the CSB fauna.

This paper presents results of new faunal and contextual analyses from the McBurney excavations (1961-78). 1,494 faunal remains were recorded from all horizons, placing the two bone heaps within context. Zooarchaeological techniques, such as species and body part identification, were allied with a range of attributes (weathering, abrasion and rootetching) to fully understand the site formation processes. Furthermore, an oblique light source and hand lens (20x magnification) allowed for a detailed assessment of bone surface modifications.

Results confirm the dominance of mammoth and woolly rhino with smaller quantities of horse, wolf and bear. Overall, per layer, Minimum Number of Individuals (MNI) are very low, usually 1 or 2 . Only within the "bone heaps" of Units 3 and 6 do mammoths dominate with MNIs of 7 and 11, respectively. Further data, however, indicates complex site formation and preservation. Bone weathering throughout all horizons, including the bone heaps, suggests more prolonged exposure, repeated input of faunal material and differential preservation, potentially related to shelter from the granite walls.

Neandertal presence was identified within all deposits by burnt bone and butchery modifications. New cut marks identified on mammoth, rhino and carnivores such as wolf and bear, suggest a more complex Neandertal subsistence pattern than previously acknowledged. Importantly, new carnivore modifications were also recognised. Overall, all horizons show little faunal variation with equal quantities and distributions of hominin and carnivore modifications, suggesting repeated return, re-use and input by carnivores, interrupted by discontinuous Neandertal occupational events.

Whilst CSB remains exceptional, this paper presents a more complex scenario for site formation and use, illustrating the complexity of Neandertal subsistence and carnivore interactions. Both Neandertal and carnivore populations regularly utilised the CSB landscape exploiting various species, particularly megafauna. The CSB ravine system could have helped both species to track and hunt animals, whilst the enclosed site structure provided protection and shelter for butchery and processing. Identifying such regular exploitation can also help provide better insight into the approximate time required for the accumulation of individual CSB horizons. Finally, placing CSB within the broader European Middle Palaeolithic context suggests that rather than Neandertal occupation, punctuated by large-scale game drives, the site is similar to other cave faunas from Europe, with an accumulative role for both hominins and carnivores.

\section{References}

CAllow P. \& CoRnFord J. M., 1986. La Cotte de St. Brelade 1961-1978: excavations by C.B.M. McBurney, Norwich, Geo Books. ScotT K., 1980. Two hunting episodes of Middle Palaeolithic age at La Cotte de Saint-Brelade, Jersey (Channel Islands). World Archaeology, 12: 137-152.

ScotT K., 1986. The large mammal fauna. In: Callow P. \& Cornford J. M. (Eds), La Cotte de St. Brelade 1961-1978 excavations by C.B.M McBurney, 433 p. 


\title{
NO SMOKE WITHOUT FIRE (MAKERS?): The SearCh For fire PROdUCtion technology in Middle Palaeolithic Europe
}

\author{
Andrew C. Sorensen ${ }^{1}$ \\ ${ }^{1}$ Faculty of Archaeology, Leiden University, Leiden (The Netherlands); a.c.sorensen@arch.leidenuniv.nl
}

The use of fire by Neandertals during the Middle Palaeolithic has been well established by archaeologists. Whether or not these people possessed the ability to make their fires artificially with the aid of tools, on the other hand, has not. To date, only one Neandertal tool exhibiting microwear traces suggestive of having been used briefly to make fire has been identified. A handful of pyrite or marcasite (sulphuric iron) mineral pieces have been recovered from Middle Palaeolithic deposits, as well, but none exhibit traces of use from making sparks. Even in the Upper Palaeolithic, good examples of fire making tools are virtually absent until later in this period.

One explanation for this paucity of Palaeolithic fire making tools could be Neandertals and Early Modern Humans were largely dependent on collecting and transporting burning materials from naturally occurring fires - fire users as opposed to fire producers. An alternate scenario is that the tools they used to make fires are simply not being recognised in artefact assemblages.

To possibly account for this, we propose the 'expedient strike-a-light model', which postulates early stone fire-makers were not formalised or specialised strike-a-lights of the kind recovered from later Neolithic and Bronze Age contexts used (exclusively) to kindle multiple fires, but instead manifest as relatively weak use traces on informal or expediently used implements (i.e. flakes, retouched tools, or any other suitable bit of siliceous material) derived from short-term forceful application against sulphuric iron, possibly only long enough to kindle a single fire.
We establish criteria to identify expedient firelighting tools based on experimental data and microwear analytical techniques, and discuss the testing of our research model on five Middle Palaeolithic assemblages: Scladina Cave and Remicourt (Belgium), Neumark Nord $2 / 2$ in Eastern Germany, eight volcano infill sites in the Eifel region of Western Germany, and La Cotte à la Chèvre (Jersey Island, UK).

Although results were negative from this limited data set, this research provides clear guidelines for recognising early stone-on-stone fire production technology. 


\title{
THE GREEN AMPHIBOLE ABUNDANCE AS A CHRONOSTRATIGRAPHIC TOOL IN MIDDLE PALAEOLITHIC SITES FROM BELGIUM
}

\author{
Paul Spagna $^{1}$, Paul Haesaerts ${ }^{1}$, Eric Meijs ${ }^{2}$ \& Stéphane Pirson ${ }^{1,3}$
}

\footnotetext{
${ }^{1}$ Department of Palaeontology, Royal Belgian Institute of Natural Sciences, Brussels (Belgium); paul.spagna@naturalsciences.be

${ }^{2}$ ArcheoGeolab, Maastricht (The Netherlands)

${ }^{3}$ Direction of Archaeology, Public Service of Wallonia, Namur (Belgium)
}

Variations in the green amphibole abundance in the lœss deposits from Belgium and neighbouring regions have been studied for more than sixty years. Different ratios of heavy minerals were defined in the literature, notably for stratigraphic purpose (e.g. Gullentops, 1954; Juvigné, 1978). First studies already emphasised the role of green amphibole, generally associated to green hornblende (gh). For several decades, amphibolerich loess was thought to be confined to the Weichselian (MIS 4-2). However, in 1984, several studies recognized amphibole-rich loss in the Late Saalian (MIS 6). Now used as a parameter on its own, the gh abundance is synthesized in the reference lœss sequence of Middle Belgium (Meijs, 2002; Pirson et al., 2009).

Recently, new samples were studied in the Belgian loess belt. Our main research objectives consist in completing and homogenizing the mineralogical stratigraphy of the Belgian lœss reference sequence by (re)analysing several sections, notably in
Romont (Eben-Emael), Remicourt and Harmignies. The changes in gh content are now documented from MIS 10 to the Weichselian and correlated from Eastern Belgium and The Netherlands to the North-West France.

An important result of our researches is that the gh abundance can be applied in lœss sections where Palaeolithic artefacts were found for chronostratigraphic purposes. A few examples will be presented. We also applied this tool to totally different depositional environments such as cave entrances, where pedostratigraphic markers are often missing. This is made possible thanks to the fact that the fine matrix of cave deposits in Belgium are often derived from reworked lossic deposits. Some examples will be exposed, mainly the study of Walou cave. The use of gh should therefore contribute refining the chronostratigraphic frame of some Palaeolithic sites in Belgium and NorthWest Europe.

\section{References}

Gullentops F., 1954. Contributions à la chronologie du Pléistocène et des formes du relief en Belgique, Louvain (Mémoires de l'Institut géologique de l'Université de Louvain, 18): 125-252.

JuVIGNÉ E., 1978. Les minéraux denses transparents des lœss de Belgique. Zeitschrift für Geomorphologie N. F., 22: 68-88.

MEIJS E., 2002. Lœss stratigraphy in Dutch and Belgian Limburg. Eiszeitalter und Gegenwart, 51: 114-130.

Pirson S., HAEsaerts P. \& Di Modica K., 2009. Cadre chronostratigraphique des principaux gisements du Paléolithique moyen du bassin de la Haine: un état de la question. In: Di Modica K. \& Jungels C. (Eds), Paléolithique moyen en Wallonie. La collection Louis Eloy (Collections du Patrimoine culturel de la Communauté française, $\left.n^{\circ} 2\right)$ : 58-77. 


\title{
MOUSTERIAN TERRITORIAL ORGANISATION: The EXample Of THE NORTheast AQUitaine Basin DURING MIS 3 AND 4
}

\author{
Alain Turq ${ }^{1,2} \&$ Jean-Philippe Faivre ${ }^{2}$ \\ ${ }^{1}$ Musée National de Préhistoire des Eyzies, Les Eyzies (France); alain.turq@culture.gouv.fr \\ ${ }^{2}$ UMR 5199 CNRS, Université Bordeaux 1, Laboratoire PACEA, Talence (France)
}

The North-East Aquitaine Basin, composed of a mosaic of contrasting ecosystems, incorporates a varied topography with highly diversified resources, both in terms of natural shelters and sources of lithic raw materials. New dates, the development of techno-economic analyses of lithic assemblages, isotopic studies, seasonality as seen from faunal assemblages, and a better understanding of environmental constraints, combined with the inclusion of a greater number of collections, both public and private, today affords an updated, more informative database for this region. This extensive record not only allows important concepts such as habitation or workshops sites, base camps, or territorial limits to be addressed, but to propose new ones such as 'preferential residence zones'. Moreover, the types of occupation and exploitation of these diverse ecosystems that comprised Neandertal subsistence territories can equally be considered in a new light.
The region's territories, as made evident by the origin of different lithic raw materials (presence or absence of lithological markers) together with the geographic distribution of sites, are delimited to the south by the valleys of the Lot and Garonne, which appear to represent a clear frontier, to the east by the first foothills of the Massif Central, to the west by the areas of Bergerac and Bordeaux, and to the north by the Périgueux region. No matter the techno-complex, all of the territories were organised around a 'preferential residence zone', the Périgord noir, itself encompassing the concentration of relevant archeo-sequences, which maintained close relations with the Bergerac region to the west, more seasonally with the Quercy to the east, and only sporadically with the eastern HautAgenais area. 


\title{
Traces OF OCCUPATION DURING THE Middle PALAeOlithic IN Less CONTEXT: SITES OF THE MONT SAINT-MARTIN IN THE HEART OF THE CITY OF LIÈGE (BELGIUM)
}

\author{
Pierre van der Sloot ${ }^{1}$, Stéphane Pirson ${ }^{2}$, Paul Haesaerts ${ }^{3} \&$ Paul Spagna $^{3}$
}

${ }^{1}$ Service de l'Archéologie, Direction extérieure de Liège I, Service public de Wallonie, Liège (Belgium);
pierre.vandersloot@spw.wallonie.be
${ }^{2}$ Direction of Archaeology, Public Service of Wallonia, Namur (Belgium)
${ }^{3}$ Operational Direction “Earth and History of Life”, Royal Belgian Institute for Natural Sciences, Brussels (Belgium)

Since the mid-1990s, the implementation of several building projects has led the Walloon Public Service to explore Pleistocene deposits preserved on the southern slope of the Mont Saint-Martin through preventive excavations on the so-called Cour Saint-Hubert and Hôtel des Comtes de Méan sites, distant from a few hundred meters. The Mont Saint-Martin, in the center of the city of Liège, corresponds to the interfluve between the Meuse to the south and a small tributary of the left bank of the river to the north, the Legia. Two other sites excavated previously, Sainte Walburge (De Puydt et al., 1912) and Rocourt (Haesaerts, 1978; Haesaerts et al., 2011), are only 2-3 km far from the Mont Saint-Martin, to the north.

The stratigraphic study of both sites has allowed for the restitution of lœss sequences of 6 to 7 meters thick, which document the main periods of the Late Pleistocene. In the lower section, a complex of soils similar to the Rocourt pedocomplex was identified. Several pedogeneses (luvisol and greyzem), attributed to the Eemian Interglacial and Weichselian Early Glacial, were recorded. The archaeological material consists exclusively of lithic artefacts, which have a flake technological component, including Levallois technology, and a laminar one. Each is documented in the pedocomplex and in an overlying gravel layer. Although stratigraphic sequences recorded in both Court Saint-Hubert and Hôtel des Comtes de Méan present some similarities, they differ substantially, particularly as regards with the sequence of events associated with the Rocourt pedocomplex, the sequence of the Hôtel des Comtes de Méan being better differentiated.

From a taphonomic point of view, there is little doubt that solifluxion had an impact on the original position of some artefacts, but its extent is unknown at this stage of the research. The same can be considered for the effect of runoff, which caused the reworking of artefacts from the pedocomplex to the overlying gravel. Accordingly, and taking into account the distribution of artefacts within several stratigraphic units, the question arises of the minimum number of occupation phases to which these objects are related to (van der Sloot et al., 2011).

\section{References}

De Puydt M., Hamal-Nandrin J. \& Servais J., 1912. Liége paléolithique. Le gisement de Sainte Walburge dans le limon hesbayen. Bulletin de l'Institut Archéologique Liégeois, XLII: 139-215.

HAESAERTS, P., 1978. Contexte stratigraphique de quelques gisements paléolithiques de plein air de Moyenne Belgique. Bulletin de la Société Royale Belge d'Anthropologie et de Préhistoire, 89: 115-133.

Haesaerts P., Di Modica K. \& Pirson S., 2011. Le gisement paléolithique de la sablière Gritten à Rocourt (province de Liège). In: M. Toussaint, K. Di Modica \& S. Pirson (Eds), Le Paléolithique moyen en Belgique. Mélanges Marguerite Ulrix-Closset (ERAUL 128, Bulletin des Chercheurs de la Wallonie Hors-série No 4): 359-374.

van der Sloot P., Haesaerts P. \& Pirson S., 2011. Les sites du Mont Saint-Martin. In: M. Toussaint, K. Di Modica \& S. Pirson (Eds), Le Paléolithique moyen en Belgique. Mélanges Marguerite Ulrix-Closset (ERAUL 128, Bulletin des Chercheurs de la Wallonie Hors-série No 4): 385-393. 


\section{MIDDLE PALAEOLITHIC IN NORTH-WEST EUROPE}

MULTIDISCIPLINARY APPROACHES

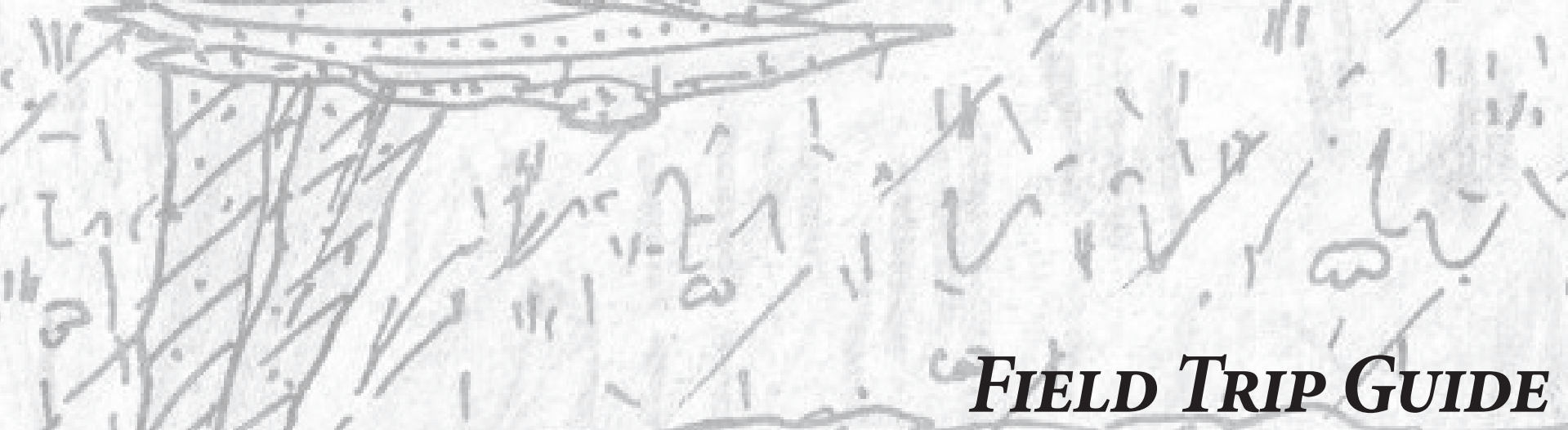





\section{Spy CaVe (BelgiUM)}

\section{Kévin Di Modica ${ }^{1}$, Stéphane Pirson ${ }^{2} \&$ Michel Toussaint ${ }^{2}$}

\footnotetext{
${ }^{1}$ Scladina Cave Archaeological Centre, Andenne (Belgium); kevin_dimodica@yahoo.fr

${ }^{2}$ Direction of Archaeology, Public Service of Wallonia, Namur (Belgium)
}

\section{Introduction}

Spy Cave is the most famous Belgian palaeolithic site, as a result of the discovery of two well-preserved Neandertal individuals in 1886 (De Puydt \& Lohest, 1887). The importance of this discovery consists not only in the Neandertal remains themselves but also in the minutes written on the field by a multidisciplinary team composed of Marcel De Puydt (archaeologist), Max Lohest (geologist) and Julien Fraipont (anthropologist) with Ivan Braconnier as a witness (De Puydt \& Lohest, 1887).

These minutes describe the stratigraphic sequence observed on the terrace and show the association of the Neandertal remains with faunal remains typical of the "Mammoth Age" as well as with Mousterian artefacts within the same "ossiferous level". For the first time in the history of palaeoanthropology, a chronological, palaeontological and cultural context was assigned to Neandertal remains.

Before Spy, the recognition of Neandertals as an extinct species anatomically different from modern humans was still highly debated due to the lack of contextual data available. Although Édouard Dupont precisely described the stratigraphic context of the Neandertal remains found at $\mathrm{La}$ Naulette, no archaeological information was associated with them. The Neandertal species - if it existed - was believed by Gabriel de Mortillet to be associated with the "Chellean" culture whereas the Mousterian was attributed to modern humans.

\section{Stratigraphy}

Like all sites that were excavated early, Spy Cave lacks precise contextual data, first and foremost in terms of stratigraphy. The description of the stratigraphy observed in 1886 varies from one publication to another. It mainly describes three "ossiferous levels", each containing archaeological and palaeontological material. In the light of current research in cave entrance deposits, it is evident that this simple subdivision obscures a much more complex situation, with more sedimentary layers, each which could have contained archaeological material (Pirson et al., in Rougier \& Semal, 2013). Moreover, later studies of the early collections of archaeological material demonstrate that more than three cultural levels are represented at Spy.

Subsequent excavations described stratigraphic sequences sometimes similar with that of 1886 , sometimes quite different. None can be accurately linked with the 1886 stratigraphy, whether concerning deposits from the terrace or inside the cave (Pirson et al., in Rougier \& Semal, 2013). Sadly, these excavations have entirely emptied the cave and it is now impossible to undertake new fieldwork at Spy.

\section{Archaeology}

The cultural succession represented at Spy has been gradually identified. Recently, a complete archaeological revision of the collections from Spy Cave has been published (Rougier \& Semal, 2013). A critical review of available stratigraphic and archaeological data led these researchers to consider the archaeological material independently from the classic stratigraphic framework. Therefore, mainly spatial, taphonomical and typological criteria were considered in order to identify the cultural levels represented at Spy.

The Middle Palaeolithic is represented by most of the archaeological material. The combination of the three kind of criteria led to identification of at least three, possibly four cultural levels from this period (Di Modica et al., and Pirson et al., in Rougier \& Semal, 2013):

1. The Mousterian from Acheulean Tradition is represented inside the cave by a few poorly preserved bifaces.

2. The Mousterian with small bifaces is attested inside the cave by poorly preserved Fäustels and probably indicating Central European influences.

3. A Mousterian related to Keilmessergruppen is represented on the terrace of the cave by a few wellpreserved Keilmesser.

4. The many well-preserved Mousterian points recovered mainly from the terrace could belong to a 
fourth cultural level, but one cannot exclude that they are part of the same cultural level as the Keilmesser.

Above this rich Middle Palaeolithic sequence, several levels belonging to the Middle to Upper Palaeolithic transition (MUPT) and the Upper Palaeolithic have been identified (Rougier \& Semal, 2013), including LRJ, Early and Late Aurignacian, three phases of Gravettian, Magdalenian, Epipalaeolithic, Mesolithic, Neolithic, Protohistory as well as historical Periods.

\section{Palaeontology}

Few studies have been undertaken on the fauna from Spy Cave (Germonpré et al., in Rougier \& Semal, 2013). A wide range of Pleistocene species have been identified, of which horse, cave hyena, mammoth, woolly rhinoceros and reindeer are the main species. Recently, hypotheses have been proposed that mammoth remains could have resulted from hunting activities by Neandertals (Germonpré et al., in press). However, evidence is lacking due to the uncertainty of the association within the same stratigraphic level with Middle Palaeolithic artefacts. An exhaustive zooarchaeological study of the fauna from Spy Cave remains to be done.

\section{Palaeoanthropology}

Spy Cave yielded both Neolithic and Neandertal remains (Fraipont \& Lohest, 1887). The study of the Neandertals constituted the heart of the work recently undertaken at the Royal Belgian Institute for Natural Sciences (Rougier \& Semal, 2013, 2014 [in press]). This led to new understanding of the Spy Neandertals. At least three individuals - including a child - were recovered from Spy. For at least the two adults, the hypothesis of a burial is plausible.

The question of the chronological and cultural context of these Neandertals is still highly debated. Recent radiocarbon dates (Semal et al., 2009) provided an age of around $36 \mathrm{ky}$ uncal. B.P. Taking into account this date as well as the position of the remains on the terrace and the archaeological data, three hypotheses can be proposed:

1. The Neandertals are associated with the Middle Palaeolithic containing Keilmesser and/or Mousterian points.

2. The Neandertal remains are contemporaneous with the LRJ, which therefore implies that the LRJ was made by Neandertals and not AMH.

3. None of the archaeological material found in Spy is strictly contemporaneous with the Neandertal remains. In such a case, the cultural context of the Neandertal remains could be any facies of the Middle Palaeolithic and MUPT.

In the current state of research, none of these hypotheses can be excluded (Di Modica et al., in Rougier \& Semal, 2013).

\section{Conclusion}

Spy Cave yielded major Neandertal remains and contained a complex stratigraphic sequence that included several Middle and Upper Palaeolithic occupations. The early date of the excavations at Spy substantially and inadvertently mixed the archaeological material. These admixtures have several origins, notably the poor stratigraphic resolution of the successive excavations, the absence of data related to the formation processes of the stratigraphic sequence, and reclassifications of the material during the many studies of the collections. However, the recent re-examination of the collections has provided interesting results and has led to a new understanding of the site. Today at least ten Palaeolithic occupation phases have been identified. Similarly, the combination of available field data, recently obtained radiocarbon dates, and anthropological analyses suggest the existence of two burials in the form of pits (Rougier \& Semal, 2014 [in press]).

\section{References}

De PuYdT M. \& Lohest M., 1887. L'homme contemporain du Mammouth à Spy (Namur). Annales de la Fédération Archéologique et Historique de Belgique, 2: 205-240.

FRAIPONT J. \& LOHEST M., 1887. La race humaine de Néanderthal ou de Canstadt en Belgique. Recherches ethnographiques sur des ossements humains, découverts dans les dépôts quaternaires d'une grotte à Spy et détermination de leur âge géologique. Archives de Biologie, VII (1886): 586-757.

GermonPrÉ M., UdRESCU M. \& Fiers É., [in press]. Possible evidence of mammoth hunting at the Neanderthal site of Spy (Belgium). Quaternary International.

RougieR H. \& Semal P. (Eds), 2013. Spy Cave. 125 years of multidisciplinary research at the Betche aux Rotches (Jemeppe-sur-Sambre, Province of Namur, Belgium). Volume 1 (Anthropologica et Praehistorica 123), $386 \mathrm{p}$.

Rougier H. \& Semal P. (Eds), 2014 [in press]. Spy Cave. 125 years of multidisciplinary research at the Betche aux Rotches (Jemeppe-surSambre, Province of Namur, Belgium). Volume 2 (Anthropologica et Praehistorica 124).

Semal P., Rougier H., Crevecoeur I., Jungels C., Flas D., Hauzeur A., Maureille B., Germonpré M., Bocherens H., Pirson S., Cammaert L., De Clerck N., Hambucken A., Higham T., Toussaint M. \& van Der Plicht J., 2009. New Data on the Late Neandertals: Direct Dating of the Belgian Spy Fossils. American Journal of Physical Anthropology, 138: 421-428. 


\section{Goyet CAVES (BelgiUM)}

\section{Michel Toussaint ${ }^{1}$, Stéphane Pirson ${ }^{1}$ \& Kévin Di Modica ${ }^{2}$}

\footnotetext{
${ }^{1}$ Direction of Archaeology, Public Service of Wallonia, Namur (Belgium); mtoussaint1866@hotmail.com

${ }^{2}$ Scladina Cave Archaeological Centre, Andenne (Belgium)
}

\section{Introduction}

The caves of Goyet form one of the major prehistoric sites of Belgium, as much because of their role in the development of regional prehistoric studies as for the number of Palaeolithic facies represented and the wealth of material recovered. The scientific importance of the caves has been acknowledged since 1868, when Édouard Dupont initiated the first excavation (Toussaint, 2001). The Goyet Cave system is located at Gesves (Prov. Namur). The Lambert coordinates of the centre of the main terrace are: $\mathrm{x}=195.71 \mathrm{~km} ; \mathrm{y}=126.20 \mathrm{~km}$ (Lambert Coordinates, I.G.N. map 48/5).

Abundant archaeological, palaeontological and palaeoanthropological material were discovered in the different caves of the site but, for the most part, with scant regard for stratigraphy or plan drawing. Like other emblematic Belgian prehistoric sites, the caves of Goyet were excavated too early and contextual information such as a stratigraphic record, stratigraphic attribution of the material and spatial data are scarce.

Édouard Dupont himself, although a better stratigrapher than his contemporaries, was more than casual when he described the layers he identified at Goyet, either in the "Troisième Caverne" or at Trou du Moulin. Since he had previously done some remarkable studies of cave deposits, notably at La Naulette, one can assume that he was already more concerned by his new duties as director of the Natural History Museum in Brussels than by furthering his cave research. It also seems that at that time, the last period of his fieldwork, technicians did most of the work on his behalf.

The many later excavations both on the terrace immediately outside the caves and within the different caves, either by individual collectors or large national institutions, were also perfunctory in character and their context is poorly known. No layer-based inventory of the documents collected by the successive diggers is available, and no distribution maps of the finds. The material is scattered in several private collections, museums and institutions, some of them outside Belgium. Laboratory analyses, conducted more than a century after the first excavations, represent the only significant work (for details, refer to Di Modica, 2009; Rougier et al., this volume).

This sorry state of affairs prompted the resumption of field research at the Goyet Caves from 1997 up to now by the Direction of Archaeology of the Public Service of Wallonia (i.e. Toussaint, 2006). In parallel, colleagues undertook a reassessment of the abundant palaeontological material from Dupont's excavations conserved at their institution (Rougier et al., this volume).

\section{Stratigraphy}

During his excavations, Édouard Dupont (1872) identified "five ossiferous layers" alternating with "six alluvial layers" in the stratigraphic sequence of the cave he described as "Troisième Caverne".

The two lower "ossiferous levels" were interpreted as animal dens, alternatively lions, cave bears and sometimes hyenas. The three upper "ossiferous levels" were related to successive human occupations. Clearly, the series of tools related to these three ossiferous layers are far from homogeneous and this testifies to Dupont's poor stratigraphic understanding at Goyet.

\section{Prehistory}

Notwithstanding the shortcomings of the first interventions, several prehistorians attempted to describe the sequence of Palaeolithic occupations of the site, which contains one of the most complete successions of industries in North-West Europe: Middle Palaeolithic, LRJ, Aurignacian, Gravettian, Magdalenian, Neolithic and historic periods.

However, these attempts suffered from a number of problems. It is quite probable that the main Palaeolithic periods identified on a strictly 
typological basis correspond to the artificial grouping of several occupation layers. Furthermore, many artefacts are difficult to attribute to a particular culture. Finally, the Middle Palaeolithic classifications used, derived from François Bordes' work in South-West France, are inapplicable to the Belgian Middle Palaeolithic (Di Modica, 2010).

\section{Palaeontology}

Fauna from Dupont's excavations come up regularly in palaeontological research. Like the other studies of the material found at Goyet in the $19^{\text {th }}$ century, this research is biased by the lack of precision of the stratigraphic context and the confusion between strata from different periods.

The most recent works focus mainly on cave bear (see Germonpré, 2009 for details). Fauna from the Magdalenian layer(s) of the third cave was also reevaluated from the perspectives of taphonomy and zooarchaeology. More recently, a canid cranium radiocarbon dated around 31,000 ky B.P. has been considered as the earliest evidence for canid domestication (Germonpré et al., 2009).

\section{Palaeoanthropology}

Most anthropological discoveries were made by Dupont and do not have a precise stratigraphic context. They have been recently rediscovered in the storerooms of the Royal Institute of Natural Sciences of Belgium and currently being studied (see Rougier et al., this volume; Wißing et al., this volume).

Various discoveries were also made by many archaeologists who excavated the site during the $20^{\text {th }}$ century, including a protohistoric knife made on a human radius (Toussaint, 2005a). So far, recent research from the Direction of Archaeology (SPW) has led to the discovery of a Neolithic burial (Toussaint, 2005b).

\section{Conclusion}

The archaeological richness of Goyet Caves was already known back in 1870 . The intensity of the careless explorations has profoundly altered the sedimentary deposits and the rich prehistoric material it contained. Barring the discovery of an undisturbed sedimentary sequence, we will never know in detail the different Palaeolithic industries present at Goyet. However, during the research undertaken since 1997, undisturbed sediments have been locally found, for example at the Upper Shelter, as well as some untouched areas in the new system of Trou du Moulin, where a Neolithic child burial has been excavated.

Much more, though, must still be done if we are to better understand the prehistory of the caves of Goyet.

In the field, several intact areas should be excavated. The most promising perspectives lie in the pristine gallery directly under the Upper Shelter.

As for laboratory work, analyses of the deposits from the Upper Shelter must be finalized, particularly the sedimentology and palynology.

The study of both the collections kept in museums and private collections might also bring some surprises, as proven by the recent re-discoveries of Neandertal and Upper Palaeolithic human remains.

\section{References}

DuPONT E., 1872. L'homme pendant les Âges de la Pierre dans les environs de Dinant-sur-Meuse, 250 p.

Di Modica K., 2009. Les grottes de la terrasse de Goyet. In: Di Modica K. \& Jungels C. (dir.), Paléolithique moyen en Wallonie. La collection Louis Éloy (Collections du Patrimoine culturel, 2): 159-173.

Di Modica K., 2010. Les productions lithiques du Paléolithique moyen de Belgique: variabilité des systèmes d'acquisition et des technologies en réponse à une mosaïque d'environnements contrastés. Ph.D. Dissertation, Université de Liège - Museum National d'Histoire Naturelle, $787 \mathrm{p}$.

Germonpré M.., 2009. La faune pléistocène de Goyet. In: Di Modica K. \& Jungels C. (dir.), Paléolithique moyen en Wallonie. La collection Louis Éloy (Collections du Patrimoine culturel, 2): 169-170.

Germonpré M., Sablin M. V., Stevens R. E., Hedges R. E. M., Hofreiter M., Stiller M. \& Despré, V. R., 2009. Fossil dogs and wolves from Palaeolithic sites in Belgium, the Ukraine and Russia: osteometry, ancient DNA and stable isotopes. Journal of Archaeological Science, 36: 473-490.

Toussaint M., 2001. Les hommes fossiles en Wallonie. De Philippe-Charles Schmerling à Julien Fraipont, l'émergence de la paléoanthropologie (Carnet du Patrimoine 33), $60 \mathrm{p}$.

TOUSSAINT M., 2005a. Un couteau aménagé dans un radius humain protohistorique découvert aux grottes de Goyet (Gesves, province de Namur, Belgique). Bulletin de la Société préhistorique française, 102(3): 625-637.

TOUSSAINT M., 2005b. La sépulture d'enfant néolithique des nouveaux réseaux du Trou du Moulin, à Goyet (Gesves, province de Namur). Anthropologica et Praehistorica, 116:179-210.

Toussaint M., 2006. 1997-2005 Research in the Cave of Goyet (Gesves, Province of Namur, Belgium), Tongeren Neandertal symposium excursion, 19 September 2004. In: Demarsin B. \& Otte M. (dir.), Neanderthals in Europe (ERAUL 117, Atuatuca 2): 115-134. 


\title{
The SEDimentary ConteXt, ARCHAEOlogy, AND ANTHRopology OF SCladina CAVE (BelgiUm)
}

\author{
Dominique Bonjean ${ }^{1,2}$, Grégory Abrams ${ }^{1,2}$, Kévin Di Modica ${ }^{1}$, Marcel Otte $^{2}$, Stéphane Pirson $^{3}$ \& \\ Michel Toussaint ${ }^{3}$
}

\footnotetext{
${ }^{1}$ Scladina Cave Archaeological Centre, Andenne (Belgium); scladina@swing.be

${ }^{2}$ Department of Prehistory, University of Liège, Liège (Belgium)

${ }^{3}$ Direction of Archaeology, Public Service of Wallonia, Namur (Belgium)
}

\section{Topography and history}

Scladina Cave is located on the west side of a small tributary of the Meuse River in Sclayn, Belgium (Commune of Andenne, Province of Namur). The cave opens towards the southeast, approximately 7 meters below a plateau. The coordinates of the site are: $50^{\circ} 29^{\prime} 33^{\prime \prime} \mathrm{N}$ and $5^{\circ} 01^{\prime} 300^{\prime \prime} \mathrm{E}$; the altitude is 137.7 meters AMSL. Scladina Cave is a long cylinderlike karst structure that extends along the axial plane of an anticline. Currently, excavation of the sediment within Scladina extends about 40 meters from the cave's entrance. Approximately 35 meters from the porch, an aven connects the cave to the surface.

At the time of the discovery (1971) Scladina Cave was filled to the vault with sediment. In August 1978, the Department of Prehistory from the University of Liège undertook the first scientific excavation at the site. Presently, excavation is carried out by the organization Archéologie Andennaise in conjunction with the University of Liège, with support from the City of Andenne and the Service public de Wallonie. In 1996, the cave was officially classified as an archaeological site and made into a site exceptionnel de Wallonie (exceptional site of Wallonia, protected by regional laws).

\section{Sedimentary context}

Since the beginning of scientific research at Scladina, multidisciplinary studies have demonstrated that the cave contains evidence of numerous climatic fluctuations belonging to the Upper Pleistocene (Otte, 1992). From a palaeoclimatic perspective, this is one of the most complete sequences available to researchers in Belgium. Beginning in 2003, a detailed reexamination of the cave's sedimentary sequence found a previously unknown depositional complexity. Presently, more than 120 layers, divided into 30 sedimentary units, have been identified in a sequence that is approximately 15 meters thick. A large number of sedimentary processes (e.g., run-off, debris flow, torrential flow, solifluction and settling) and postdepositional processes (e.g., deep frost, cryoturbation, bioturbation, precipitation of iron hydroxide and manganese dioxide) are understood, which makes Scladina an excellent reference site (Pirson, 2007).

\section{Archaeological context}

Scladina is one of the major Palaeolithic archaeological sites in Belgium (Otte et al., 1998; Bonjean et al., 2011). Two important Middle Palaeolithic artefact series have been recovered: the assemblages from sedimentary units 5 and $1 \mathrm{~A}$, which have been studied from a variety of perspectives, including typology, technology, petrography, spatial distribution, and statistics.

\section{Sedimentary unit 5}

Sedimentary Unit 5 is composed of several sedimentary layers, which are the result of depositional events that redistributed artefacts in the cave. Most of the environmental elements, such as palynology, sedimentary dynamics, and magnetic susceptibility point to very cold climatic conditions during its deposition: a cold phase of the Weichselian Early Glacial.

This lithic assemblage is characterized by flint transported to the cave in the form of small, crudely sculpted nodules, some quartz and quartzite pebbles collected from the Meuse alluvium near the cave, and some blocks of limestone and chert that are available near the site. Guided by a desire to economize, these materials were exploited through flexible and complementary methods (Di Modica, 2010). Tens of quartzite pebbles recovered from former layer 5 show characteristics of their use as stone hammers and 26 large diaphyseal fragments of bone that were used as retouchers. 
Faunal analysis shows that six whole chamois had been taken to the site and processed in order to obtain meat, marrow, tendons and skins. They were likely packaged for transport to another site, suggesting that Scladina may have been a hunting camp. The predation of small game was also illustrated by the presence of a coxal bone of a hare bearing 18 butchery marks. Finally, more than 1000 burned bone fragments have been collected, illustrating the existence of one or several hearths.

\section{The assemblage of unit $1 \mathrm{~A}$}

The first layer in which this artefact assemblage appears is $1 \mathrm{~A}-\mathrm{GL}$, which is dated to between $40,210+400 /-350$ B.P. and 37,300 +370/-320 B.P., corresponding to the Weichselian Middle Pleniglacial (MIS 3). With approximately 4500 artefacts, this assemblage is the second most valuable archaeological series at the site. Unlike the assemblage of Sedimentary Unit 5, the assemblage from Unit $1 \mathrm{~A}$ is characterized by a poorer state of preservation, heterogeneity of patina, highly abraded edges of the flint artefacts, as well as less circumscribed planimetric and stratigraphic distribution (Di Modica, 2010).

\section{The juvenile Neandertal remains of Scladina}

Since 1993, an emotional dimension has been part of excavation at Scladina. This was induced by the recovery of a mandible, a maxillary fragment, and 16 isolated teeth of an 8 year-old Neandertal from Sedimentary Complex 4A (Toussaint et al., 1998; Toussaint \& Bonjean, 2014). This discovery, the most important made in Belgium in the $20^{\text {th }}$ century, permitted Scladina to join several other Belgian sites that have yielded Middle Palaeolithic human remains. Dated to approximately 100,000 B.P., the oldest Neandertal DNA was retrieved from this individual (Orlando et al., 2006).

\section{References}

Bonjean D., Di Modica K., Abrams G., Pirson S. \& Otte M., 2011. La grotte Scladina: bilan 1971-2011. In: Toussaint M., Di Modica K. \& Pirson S. (Dir.), Le Paléolithique moyen en Belgique. Mélanges Marguerite Ulrix-Closset (ERAUL 128, Bulletin des Chercheurs de la Wallonie Hors-série No 4): 323-334.

Di Modica K., 2010. Les productions lithiques du Paléolithique moyen de Belgique: variabilité des systèmes d'acquisition et des technologies en réponse à une mosaïque d'environnements contrastés. Ph.D. Dissertation, Université de Liège - Museum National d'Histoire Naturelle, $787 \mathrm{p}$.

Orlando L., Darlu P., Toussaint M., Bonjean D., Otte M., Hänni C., 2006. Revisiting Neandertal Diversity with a 100,000 year old mtDNA Sequence. Current Biology, 16 (11): R400-R402.

OtTE M. (Ed.), 1992. Recherches aux grottes de Sclayn, vol.1: Le Contexte (ERAUL, 27), 182 p.

Otte M., Patou-Mathis M. \& Bonjean D., (Eds), 1998. Recherches aux grottes de Sclayn, vol.2: L’Archéologie (ERAUL, 79), $437 \mathrm{p}$.

PIRSON S., 2007. Contribution à l'étude des dépôts d'entrée de grotte en Belgique au Pléistocène supérieur. Stratigraphie, sédimentogenèse et paléoenvironnement. Ph.D. Dissertation, Université de Liège - Institut royal des Sciences naturelles de Belgique, 2 volumes, 435 p. \& 5 appendices.

Toussaint M., Otte M., Bonjean D., Bocherens H., Falguères C. \& Yokoyama Y., 1998. Les restes humains néandertaliens immatures de la couche 4A de la grotte Scladina (Andenne, Belgique). Académie des Sciences de Paris, 326: 737-742.

TousSAINT M. \& BONJEAN D. (Dir.), 2014 [in press]. The Juvenile Neandertal Remains from Scladina Cave (ERAUL, 134). 


\section{ALPHABETICAL INDEX OF AUTHORS}

\section{A}

Abrams Grégory, 1, 5, 12, 17, 19, 49, 50, 75

Alix Philippe, 54

Anderung Cia, 58

Andrews Julian, 56

Antoine Pierre, 6, 30, 31, 56

Ashton Nick, 7, 25

Auguste Patrick, 5, 8, 30, 54

\section{B}

Bahain Jean-Jacques, 6 Bates Martin, 9; Richard, 9

Beauval Cédric, 35, 46

Bello Silvia M., 5, 49

Benjamin Jonathan, 43

Bertran Pascal, 10

Bicket Andrew R., 43

Blain Hugues-Alexandre, 50

Blaser Frédéric, 11

Blinkhorn Ed, 9

Bocherens Hervé, 12, 35, 46

Bodu Pierre, 29

Bolton Lucie, 51

Bonjean Dominique, 1, 12, 49, 50, 55, 75

Bosinski Gerhard, 13

Bosquet Dominique, 52

Bourguignon Laurence, 25

Brenet Michel, 25

Busschers Freek, 26

Bynoe Rachel, 14

\section{C}

Carbonel Pierre, 56

Chaussé Christine, 11, 56

Cliquet Dominique, 25, 54

Cohen Kim, 26

Conneller Chantal, 9

Coppe Justin, 55

Cordy Jean-Marie, 50

Cotte Martin, 12

Coudenneau Aude, 23

Court-Picon Mona, 15, 59

Coutard Jean-Pierre, 54; Sylvie, 6, 31

Crevecoeur Isabelle, 35, 41, 46

\section{D}

Dabkowski Julie, 30, 56
Damblon Freddy, 16, 52, 59

Daujeard Camille, 17

De Groote Isabelle, 58

De Loecker Dimitri, 43, 45

De Wilde Bjorn, 59

Debenham Nick, 6, 59

Deneuve Émeline, 54

Depaepe Pascal, 18

Di Modica Kévin, 1, 12, 19, 25, 32, 49, 50, 55, 61, 71, 73, 75

Dix Justin, 14

Draily Christelle, 59

\section{F}

Faivre Jean-Philippe, 25, 67

Flas Damien, 21, 35, 46

\section{G}

Gamble Clive, 9

Gaudzinski-Windheuser Sabine, 5

Gautier Agnès, 54

Germonpré Mietje, 5, 17, 35, 46

Ghaleb Bassam, 30

Glauberman Phil, 22

Goval Émilie, 6, 23, 31

Guérin Gilles, 6

\section{H}

Haesaerts Paul, 24, 52, 66, 68

Hérisson David, 6, 25, 31

Higham Tom, 58

Hijma Marc, 26

Hoggard Christian S., 60

Horevoets Michael, 61

Hublin Jean-Jacques, 27, 44

\section{J}

Jardón Giner Paula, 52

Julien Marie-Anne, 9

Juvigné Étienne, 61

K

Kindler Lutz, 5

Kitagawa Keiko, 5

Krönneck Petra, 5

Kruszynski Rob, 58 


\section{L}

Lamotte Agnès, 62

Le Brun-Ricalens Foni, 28

Leroyer Mathieu, 29

Lewis Simon, 7

Lhomme Vincent, 29

Limondin-Lozouet Nicole, 30, 56

Locht Jean-Luc, 6, 23, 25, 30, 31, 56

López-García Juan Manuel, 50

\section{M}

Marca-Bell Alina, 56

Marcoux Nancy, 54

McNabb John, 9

Meijs Eric, 66

Mercier Norbert, 54

Moine Olivier, 54

Moncel Marie-Hélène, 25

Münzel Susanne, 5

\section{$\mathbf{N}$}

Niekus Marcel J.L.Th., 45, 63

\section{o}

Otte Marcel, 75

\section{$\mathbf{P}$}

Parfitt Simon, 5

Pirson Stéphane, 1, 19, 32, 49, 50, 59, 61, 66, 68, 71, 73, 75

Plisson Hugues, 54

Ponel Philippe, 54

Pope Matt, 9, 25

\section{$\mathbf{R}$}

Rensink Eelco, 45

Richards Michael P., 44

Richter Jürgen, 33

Roebroeks Wil, 18, 25, 26

Rots Veerle, 34
Rougier Hélène, 35, 41, 46

Ruebens Karen, 36

Ryssaert Caroline, 52

\section{S}

Salomon Hélène, 29

Schirmer Wolfgang, 38

Schwarz Sarah, 40

Scott Beccy, 7, 9, 25

Semal Patrick, 35, 41, 46

Shaw Andy, 9

Smith Geoff M., 5, 64

Sorensen Andrew C., 65

Spagna Paul, 32, 66, 68

Stapert Dirk, 63

Stevens Rhiannon, 58

Stoetzel Emmanuelle, 54

Stringer Chris, 42, 58

Sturt Fraser, 14

T

Tizzard Louise, 43

Toussaint Michel, 1, 19, 44, 59, 71, 73, 75

Tribouillard Élisabeth, 54

Turq Alain, 25, 67

\begin{tabular}{|c|}
\hline $\mathbf{V}$ \\
\hline \hline
\end{tabular}

Van Baelen Ann, 25

van der Plicht Johannes, 35, 46

van der Sloot Pierre, 68

van Kolfschoten Thijs, 5

Van Neer Wim, 59

Van Peer Philip, 25

Van-Vliet Lanoë Brigitte, 54

Verna Christine, 44

Verpoorte Alexander, 45

\section{W}

Westerhoff Wim, 26

Wißing Christoph, 12, 35, 46

Wouters Wim, 59 



